Andrews University

Digital Commons @ Andrews University

2010

\title{
A Strategy To Mobilize Seventh-day Adventists in Lusaka in Response to the HIV/AIDS Crisis
}

Harrington Simui Akombwa

Andrews University

Follow this and additional works at: https://digitalcommons.andrews.edu/dmin

Part of the Practical Theology Commons

\section{Recommended Citation}

Akombwa, Harrington Simui, "A Strategy To Mobilize Seventh-day Adventists in Lusaka in Response to the HIV/AIDS Crisis" (2010). Professional Dissertations DMin. 475.

https://dx.doi.org/10.32597/dmin/475

https://digitalcommons.andrews.edu/dmin/475

This Project Report is brought to you for free and open access by the Graduate Research at Digital Commons @ Andrews University. It has been accepted for inclusion in Professional Dissertations DMin by an authorized administrator of Digital Commons @ Andrews University. For more information, please contact repository@andrews.edu. 


\title{
ABSTRACT
}

\section{A STRATEGY TO MOBILIZE SEVENTH-DAY} ADVENTISTS IN LUSAKA IN RESPONSE

TO THE HIV/AIDS CRISIS

\author{
by
}

Harrington Simui Akombwa

Adviser: Skip Bell 


\author{
ABSTRACT OF GRADUATE RESEARCH \\ Dissertation Project \\ Andrews University \\ Seventh-day Adventist Theological Seminary
}

Title: A STRATEGY TO MOBILIZE SEVENTH-DAY

ADVENTISTS IN LUSAKA IN RESPONSE

TO THE HIV/AIDS CRISIS

Name of researcher: Harrington Simui Akombwa

Name and degree of faculty chair: Skip Bell, D.Min.

Date completed: September 2010

\title{
Problem
}

While Zambia is rated the 7th country worst affected by HIV/AIDS worldwide, the Seventh-day Adventist (SDA) Church, an Faith Based Organization (FBO) well respected nationwide for its concern about people's physical health because of its hospitals and clinics around the nation, is seemingly standing by doing close to nothing. What could be the problem?

\section{Method}

To uncover the possible causes of Adventists' perceived noncommittal stance on the AIDS issue, a survey designed around a descriptive and exploratory social research model utilizing quantitative research techniques for data collection and analysis was 
conducted. The survey was conducted in 2 of the most prominent SDA churches in Lusaka, Zambia, using self-structured questionnaires and the data analyzed using descriptive graphic techniques.

\section{Results}

The survey not only confirmed the perception that the SDA Church is un involved in the fight against AIDS, but also the existence of deep seated stigma against HIV and people living with AIDS (PLWA) in the church. More significantly, the study associated the prevailing stigma to Adventism's strict view of obedience, which, ironically, has the tendency to depreciate those deemed to have failed to obey. This attitude, the result of deeply held stigma, unfortunately, is what curtails compassion, leading to reluctance to help those who are suffering.

\section{Conclusions}

It is rather ironic that the SDA Church's commendable high regard for obedience would work against it. However, giving SDAs an understanding of compassion as exemplified in Jesus' life and ministry would not only help curb the problem of stigma but also motivate and empower them to be actively engaged in the fight against the AIDS epidemic on a voluntary basis. Doing this would not only help scale up the fight against HIV/AIDS, but also enhance the Church's mission. 
Andrews University

Seventh-day Adventist Theological Seminary

\title{
A STRATEGY TO MOBILIZE SEVENTH-DAY ADVENTISTS \\ IN LUSAKA IN RESPONSE TO THE HIV/AIDS CRISIS
}

\author{
A Dissertation Project \\ Presented in Partial Fulfillment \\ of the Requirements for the Degree \\ Doctor of Ministry
}

by

Harrington Simui Akombwa

September 2010 
CCopyright by Harrington Simui Akombwa 2010

All Rights Reserved 


\title{
A STRATEGY TO MOBILIZE SEVENTH-DAY ADVENTISTS IN LUSAKA IN RESPONSE TO THE HIV / AIDS CRISIS
}

\author{
A project \\ presented in partial fulfillment \\ of the requirements for the degree \\ Doctor of Ministry
}

by

Harrington Simui Akombwa

APPROVAL BY THE COMMITTEE:
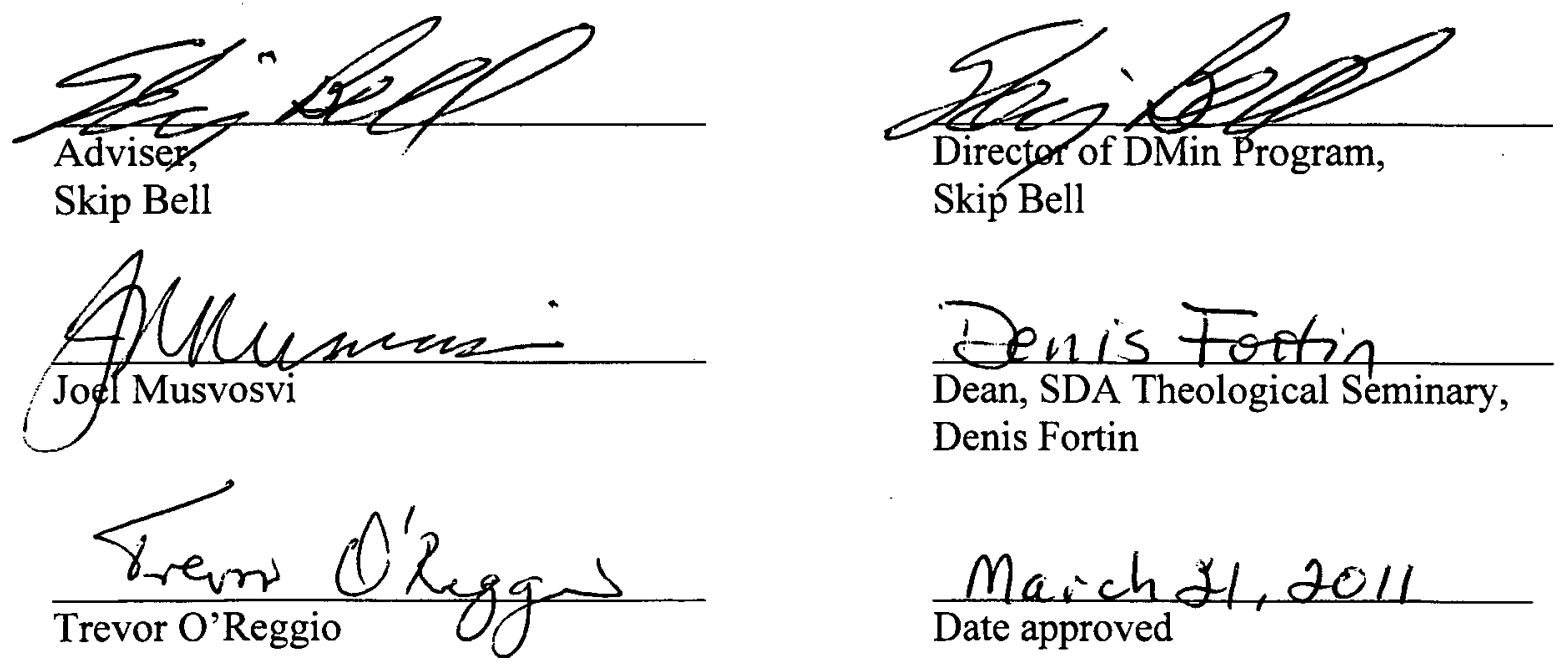


\section{DEDICATION}

This doctoral dissertation project is dedicated to the following people:

To the late Mr. Leonard Akombwa Mukosiku, my beloved father, who, though denied the chance of getting an education himself, sent me to school before I was even six years old. This achievement is really his.

To my beloved wife and friend, Given, whose urging 23 years ago started me off on my academic trip that has led to this doctoral degree.

To our five sons, Benaiah, Samuel, Moses, Peter, and David; may this doctoral dissertation motivate each one of you to settle for nothing less! In the words of President Barack Obama, "Yes, you can!" 


\section{TABLE OF CONTENTS}

LIST OF FIGURES ……………….................................................................. VI

LIST OF TABLES ……................................................................................. VI

LIST OF ABBREVIATIONS ......................................................................... VII

ACKNOWLEDGEMENTS.................................................................................. IX

Chapter

I. INTRODUCTION ……............................................................................

Historical Context ............................................................................... 1

Statement of the Problem ..................................................................... 2

Statement of the Task..................................................................... 2

Justification of the Project......................................................................... 3

Description of the Process...................................................................... 4

Expectations From the Study ......................................................... 5

Limitations ...................................................................................... 6

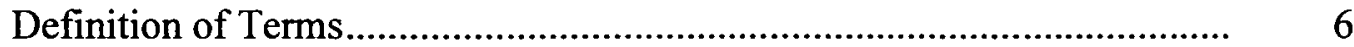

Methodology ................................................................................. 25

Conclusion ................................................................................ 25

II. THE THEOLOGICAL FOUNDATION FOR CHRISTIAN
INVOLVEMENT IN THE FIGHT AGAINST HIV/AIDS ...................... 27

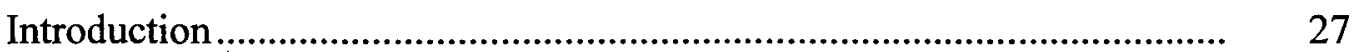

Compassion: The Springboard of Jesus' Ministry ………........................... 29

Compassion in the Old Testament ................................................... 29

Compassion in the New Testament.................................................. 30

The Significance of Compassion to Hebrew Faith ............................. 33

Jesus' Attitude Toward Suffering ..................................................................

The Healing of a Man Suffering From Leprosy ................................ $\quad 36$

The Healing of the Paralytic Man ...................................................... 37

The Healing of the Man by the Pool of Bethesda .............................. 38

The Parable of the Last Judgment..................................................... 39

The Parable of the Good Samaritan ................................................... 40

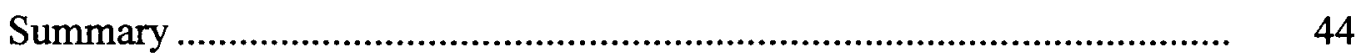


III. HIV/AIDS PANDEMIC: LITERATURE SURVEY ................................. 46

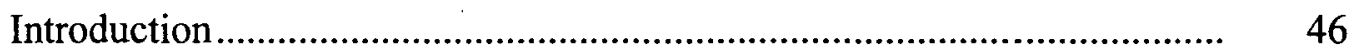

The Development and Origin of HIV and AIDS ................................... 47

Development of HIV ................................................................... 47

The Origins of HIV/AIDS ............................................................. 48

The Impact of HIV/AIDS .................................................................. 49

Strategies to Combat HIV and AIDS ..................................................... 53

Challenges Hampering the HIV and AIDS Fight .................................... 58

The Role of FBOs in Combating HIV/AIDS and Stigma............................ 66

Strategies for Sustainable Response ......................................................... 68

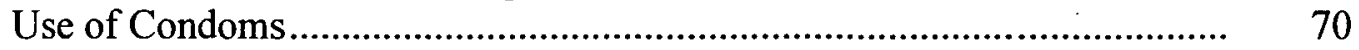

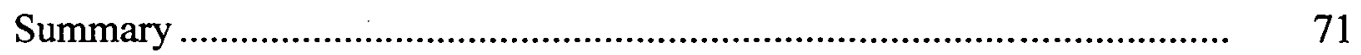

IV. THE INVOLVEMENT OF THE SEVENTH-DAY ADVENTIST CHURCH IN THE FIGHT AGAINST HIV/AIDS IN ZAMBIA .............. 73

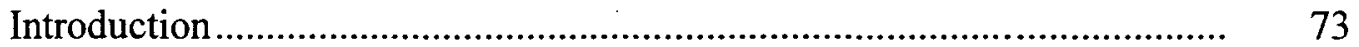

Indirect-Participant-Observer Cases ........................................................ $\quad 75$

Why Does Not Our Church Discipline AIDS Patients? .................... $\quad 75$

Two Sisters, Two Different Stories ................................................. 78

My Unbelieving Brother Versus My Ministerial Colleagues ............ $\quad 79$

Conclusion ................................................................................ $\quad 80$

Survey of SDA Members: Research Design and Methodology ................ $\quad 80$

Findings of the Survey .......................................................................... $\quad 89$

Graphic Descriptive Analysis of Questionnaire Findings ................ $\quad 89$

Implications of the Survey Findings ............................................................ 93

Analysis of Research Findings................................................................ 96

Summary and Conclusion ....................................................................... 102

\section{A STRATEGY TO ENGAGE SDA CHURCH MEMBERS IN THE}

FIGHT AGAINST HIV/AIDS ................................................................. 103

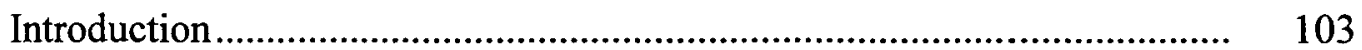

Organizing the Church for Compassionate Service .................................... 106

Monitoring and Evaluation ....................................................................... 118

Summary and Conclusion .................................................................... 120

VI. SUMMARY, CONCLUSION, AND RECOMMENDATIONS................. 122

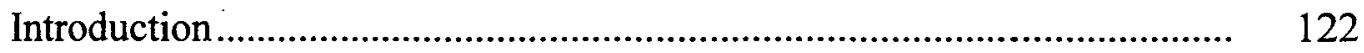

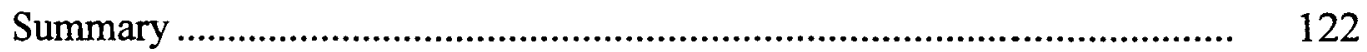

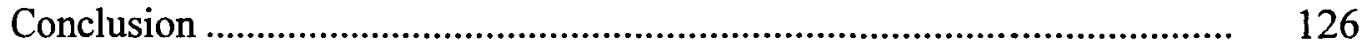

Recommendations ....................................................................... 127

Appendix

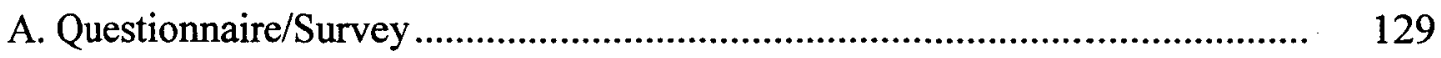


B. Local Church Monitoring and Evaluation Instrument ............................... 131

C. SDA Church AIDS Epidemic Guidelines ................................................. 133

D. AIDS-A Seventh-Day Adventist Response .......................................... 135

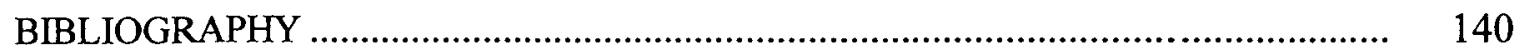

VITA 


\section{LIST OF FIGURES}

1. Sources of Information About HIV/AIDS.

2. Effect of HIV/AIDS ........................................................................... 90

3. Percentage of Membership Involved in Combating HIV/AIDS .................... 91

4. Degree to Which Members Perceive Leaders to Be Involved in the Effort to Combat HIV/AIDS

5. Members Stigmatize Those Suffering From HIV/AIDS ….......................... 92

6. Members Willingness to Provide Humanitarian Assistance to HIV/

AIDS Victims

\section{LIST OF TABLES}

1. Summary of Response to Question 1 ……............................................... 84

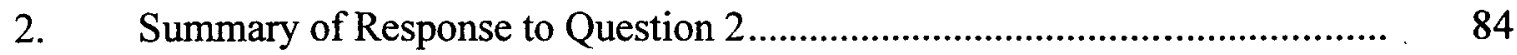

3. Summary of Response to Questions $3,5,6,15,16$, and 17 ........................ 85

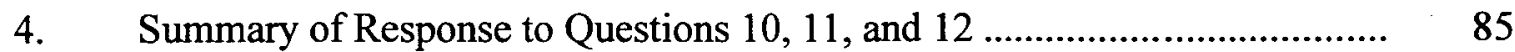

5. Summary of Response to Question 4 .......................................................... 86

6. Summary of Response to Question 7 ............................................................ 86

7. Summary of Response to Question 8 ………................................................ 87

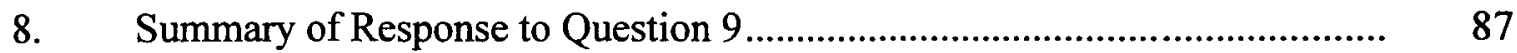

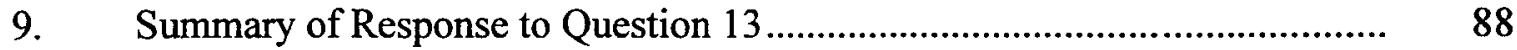

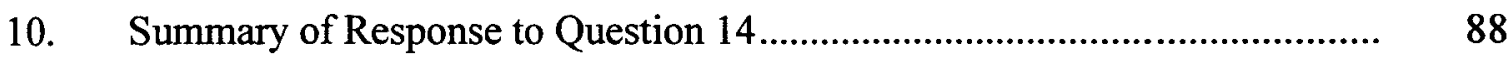




\section{LIST OF ABBREVIATIONS}

$3 \mathrm{Cs}$

ACSA

AIDS

AIAM

ART

ARV

DNA

FBO

GC

GHAP

GRZ

HAART

HIV

IEC

ILO

KJV

MDG

M\&E

MSM

MTCT confidentiality, informed consent, and counseling

Anglican Church of Southern Africa

Acquired Immune Deficiency Syndrome

Adventist International AIDS Ministry

antiretroviral therapy or antiretroviral treatment

antiretroviral drug

Deoxyribonucleic acid

Faith Based Organization

General Conference of Seventh-day Adventist

Global HIV/AIDS Program, the

Government of the Republic of Zambia

Highly Active Antiretroviral Therapy

Human Immunodeficiency Virus

information, education, and communication

International Labor Organization, the

King James Version

Millennium Development Goals

monitoring and evaluation

men who have sex with men

mother-to-child transmission 


$\begin{array}{ll}\text { NAC } & \begin{array}{l}\text { National AIDS Coordinating Authority formerly National AIDS } \\ \text { NASB }\end{array} \\ \text { NASF } & \text { National HIV and AIDS Strategic Framework } \\ \text { NIV } & \text { New International Version } \\ \text { RNA } & \text { Ribonucleic Acid } \\ \text { PLHIV } & \text { people living with HIV } \\ \text { PLWA } & \text { people living with AIDS } \\ \text { SDA } & \text { Seventh-day Adventist } \\ \text { SES } & \text { Socioeconomic Status } \\ \text { SESDA_AIDS } & \text { Strategy to engage Seventh-day Adventists in the fight against } \\ \text { HTI } & \text { Sexually Transmitted Infection } \\ \text { TB } & \text { Tuberculosis } \\ \text { UN } & \text { United Nations } \\ \text { UNAIDS } & \text { United Nations Programme on HIV/AIDS } \\ \text { UNDP } & \text { United Nations Development Programme } \\ \text { VCT } & \text { voluntary counselling and testing } \\ \text { WHO } & \text { World Health Organization } \\ \text { ZARAN } & \text { Zambia AIDSLAW Research \& Advocacy Network } \\ \text { NAS } & \end{array}$




\section{ACKNOWLEDGEMENTS}

I would like to acknowledge the assistance received from the following people leading to and during the time I was working on this dissertation:

Dr. Skip Bell and Dr. Joel Musvosvi, my Advisor and second reader respectively; their timely advice, constant encouragement, and patience have been very helpful and affirming and led to this achievement. Dr. Musvosvi has been my mentor since my early theological training years at Solusi University. I would also like to thank Dr. Stan Patterson for his invaluable editorial assistance.

Dr. J. S. R. Malungo, Dean of the School of Social Sciences at the University of Zambia, Lusaka, Zambia for the hours he spent with me giving me ideas regarding my project, as well as for the books he suggested to me for my literature review.

Dr. Paul Shongwe, Director of Development and Public Relations, Zambia Adventist University, Monze, Zambia for sharing his research and some very valuable books with me.

Dr. Harold and Mrs. Verna Peters, formerly of Solusi, but now retired. I would not have made it this far if it was not for their financial assistance and love at Solusi.

Mr. John Chipimpi and Dr. Wagau Maritu, both of Helderberg College, Cape Town; the former for doing the graphics used to analyze the study and for his encouragement since 1986, and Dr. Maritu for her confidence in my capability since Solusi days when I did a business minor with her. 


\section{CHAPTER 1}

\section{INTRODUCTION}

\section{Historical Context}

The current HIV/AIDS situation in the Republic of Zambia is graphically depicted by Elizabeth Colson (2005): "At the beginning of the 21st century Zambia has one of the world's highest rates of HIV infection. Its people know ... and live with AIDS" (p. 1). And the impact of the epidemic on the lives of people in general, especially on those living in the capital city, Lusaka, is portrayed by Douglas Webb (1997):

The impact of HIV/AIDS is evident all around. Absenteeism of colleagues and friends from work for funerals is now so regular as to be expected. Leopard's hill Cemetery on the outskirts of the city is growing at a phenomenal rate. The road leading to it from the city's main hospital is occupied daily by a series of funeral processions: trucks, buses and open bakkies, full of singing women. The only blooming industry in eastern Lusaka near the cemetery is the small-scale production of headstones and plastic wreaths, which are then collected from the gravesides and resold. Death is an industry in Lusaka and emotional immunity to the death toll is necessary to continue working in a country where between 20 to 30 per cent of adults are HIV-positive, and thus destined to die within the next ten or so years. (pp. xi-xii)

It is not surprising then that the Government itself describes the HIV situation in the country as "peculiar and particularly difficult" (GRZ, 2006). The latest estimates

place Zambia as the seventh worst affected country worldwide:

Zambia has the seventh highest rate of HIV infection in the world (UNAIDS, 2008), and the AIDS epidemic remains among the most serious threats to development in spite of having a national response in place for more than 25 years. HIV and AIDS directly threaten the human capital base through widespread illness and death, and causes public, private and household capital to be diverted from investment to treatment, care and support. (p. 3) 
Meanwhile, there are 85,000 Seventh-day Adventist (SDA) church members in Lusaka who meet in some 110 congregations every week for church services. As a large and visible faith community in Lusaka, the SDA church could be a powerful social force in mitigating the HIV/AIDS crisis, and implementing interventions that could change the lives and futures of thousands of persons living with and dying of HIV/AIDS. However, responsible involvement in such a critical community issue is minimal. Adventists do participate in World AIDS day celebrations and operate hospitals, like several other Faith-based organizations (FBOs).

\section{Statement of the Problem}

With 85,000 members, the SDA church is a large and visible faith community in Lusaka, and could be a powerful social force in the HIV/AIDS crisis. However, Adventists are not providing leadership in the fight against HIV/AIDS. Anecdotal reports from Adventist pastors, members, and from community residents show that this lack of involvement in so critical a social issue has negatively affected the image of the SDA Church. Consequently, the Church's evangelistic initiatives are judged by many community residents to be hypocritical and unrelated to everyday life. Additionally, the retention of members infected with, or affected by HIV/AIDS, is poor and many new and less mature believers confused by the church's lack of involvement get attracted to other faith groups that seem to be more caring.

\section{Statement of the Task}

The task of this project is to determine the reason for the lack of SDA involvement in the fight against HIV/AIDS and develop a strategy to mobilize Adventists in selected Lusaka churches to get involved in a ministry of compassion intended to 
mitigate and combat HIV/AIDS. The strategies will be intentional and their results evaluated.

\section{Justification of the Project}

In his preface statement to the 2006 UN Report on HIV/AIDS, former UN Secretary General Kofi Annan poignantly sums up the impact that HIV/AIDS has had on the world to-date as follows: "AIDS has fundamentally changed our world—killing more than 25 million men and women, orphaning millions of children, exacerbating poverty and hunger, and, in some countries, even reversing human development altogether. Nearly 40 million people are living with AIDS today" (Annan, 2006, n.p.). Even more significantly, the report (UNAIDS, 2006a) highlights and bemoans a critical "shortage of leadership and human compassion" hindering the fight against HIV/AIDS (p. 3).

The critical "shortage of leadership and compassion" highlighted above is expected to result in many people getting infected with the virus whose infection could have been prevented, and many more people dying whose lives could have been spared. But, with leadership and compassion, these infections and deaths could be prevented through the implementation of a comprehensive range of evidence-based prevention measures (UNAIDS, 2006a, p. 5).

The SDA Church in Zambia has shown commendable concern about people's wellbeing evidenced by its setting up and operation of several medical institutions across the country. Surprisingly, such concern is lacking regarding the raging HIV/AIDS pandemic. The reasons for the perceived aloofness of many SDAs in Lusaka in the fight against HIV/AIDS need to be established. 
The thesis of this study is that if given a proper understanding of Jesus' ministry of compassion and rightly mobilized, SDA church members in Lusaka would respond to the humanitarian crisis engendered by HIV/AIDS. Furthermore, the involvement of many Christians in the fight against HIV/AIDS would not only help scale up the fight, but also be a powerful testimony in favor of Christianity.

\section{Description of the Process}

Theological reflection will examine selected passages in the New Testament that deal with Jesus and suffering people in order to establish biblical principles for dealing with suffering. Literature will be reviewed on HIV/AIDS in order to establish the extent and effect of the pandemic as well as to become conversant with the strategies/efforts being employed to contain the pandemic.

Questionnaires will be sent out to selected Adventist and non-Adventist congregations to ascertain the level to which the churches in Lusaka are involved in the HIV/AIDS crisis. The reasons Christians choose to involve themselves or refrain from involvement will be sought as well as the degree to which theological views shape those decisions.

A connection will be made with the UNAIDS (Joint United Nations Programme on HIV/AIDS) office in Zambia, the University Teaching Hospital, and the Inter-Faith Network for HIV/AIDS, all based in Lusaka, to get their assessment of the HIV/AIDS situation in the country and what role they think FBOs should play in the fight against HIV/AIDS. 
Interviews will be held with individuals known to be living with AIDS both within the Adventist Church and outside of the church to know what those who are living with HIV/AIDS expect of society in general and the church in particular.

The data will then be analyzed and used to develop a strategy to mobilize Adventists to play an active part in the fight against HIV/AIDS. Seminars will be conducted in order to share information, as well as to mobilize members to take an active part in responding to the HIV/AIDS crisis. Two selected Adventist churches in Lusaka will be used in a pilot program to implement a "Ministry of Hope" project to assist HIV/AIDS infected or affected by the disease. An evaluation instrument will be developed to assess the effectiveness of the project.

\section{Expectations From the Study}

It is the purpose of this project to awaken Adventist church members to their Godgiven responsibility to show love and care to those who are suffering.

The harmony between Adventist teaching and practice in caring for the suffering needs restoration. Ultimately, this study should help the Adventist Church emerge as the remnant of prophesy that it claims to be by prophetic decree as more and more people notice its genuine love and Christianity expressed in practical compassionate deeds towards people created in God's image but now devastated by HIV/AIDS.

The study ultimately will help the fight against HIV/AIDS by motivating and enrolling men, women, and children in the fight against this great human catastrophe. The motivation will not be fiduciary gain but an expression of the love of God who so loved them that He gave all to redeem them and their neighbors. 
This study should also assist the fight against HIV/AIDS by making coordination easier and more efficient. Many churches have an excellent communication and monitoring system that reaches to the most remote places. Such networking should provide an inexpensive mechanism through which efficient and proven interventions can reach areas until now left out of most efforts.

\section{Limitations}

The project intends to create a favorable environment for an HIV/AIDS intervention strategy on the part of two selected churches in the capital city, Lusaka. While the intervention is purposeful and can have a broader impact in the years extending beyond this study, the project itself is not a national or global intervention. Evaluation will be limited to effect on the Adventist members of those two churches regarding their attitudes and behaviors in response to the pandemic.

The research is qualitative and helpful only for the purposes of this project; it is not intended to be used for interpretation beyond the immediate context of the churches and the intervention.

\section{Definition of Terms}

Since the onset of the AIDS pandemic a whole set of new terminologies and vocabulary hitherto unknown have come into usage. It has been rightly noted that "language shapes beliefs and may influence behaviors" (UNAIDS, 2007, p. 3). Thus, considered use of appropriate language has the power to strengthen the response. Therefore, the purpose of this section is to familiarize the reader with the meanings of and contemporary usage of the selected words. Where appropriate, effort is made to draw the attention of the reader to shifts in meaning and usage of some of the terms. 
Additionally, the terminology serves the purpose of providing information on the issues and dynamics in the evolving global fight against the HIV/AIDS pandemic. The list also includes terminology not related to HIV and AIDS but relevant to the context of this research.

The list is largely based on the UNAIDS' preferred terminology developed for use by staff members, colleagues in the Programme's 10 co-sponsoring organizations, and other partners involved in the global response to HIV. The list of terminology is gratefully used with the express permission of UNAIDS (2007) for anyone wishing to do so to use their terminology: "This list may be freely copied and reproduced provided that it is not done so for commercial gain" (p. 3).

The terms are arranged in alphabetical order.

Adventist: The shorter form for Seventh-day Adventist (SDA). These terms are used interchangeably throughout the study.

AIDS: The abbreviated form of acquired immunodeficiency syndrome referring to a syndrome of opportunistic infections and diseases that can develop as immunosuppression deepens along the continuum of HIV infection from primary infection to death.

AIDS Virus: There is no AIDS virus. The virus associated with AIDS is called the Human Immunodeficiency Virus, or HIV. Please note: the phrase HIV virus is redundant. AIDS-Infected: The term infected in this context is not accurate. Use person living with HIV or HIV-positive person. No one can be infected with AIDS, because it is not an infectious agent. 
AIDS Test: This term is not appropriate. There is no test for AIDS. Use HIV or HIV antibody test.

AIDS Sufferer or Victim: The word victim is disempowering. Use person living with HIV. Use the term AIDS only when referring to a person with a clinical AIDS diagnosis.

AIDS Patient: Use the term patient only when referring to a clinical setting. It is preferred to say patient with HIV-related illness.

AIDS Carrier: This term often is used to mean any person living with HIV. However, it is stigmatizing and offensive to many people living with the virus. It is also incorrect, since the agent being carried is HIV not AIDS.

Related Illnesses: AIDS is what people die of; HIV is what they are infected with. But the expression AIDS-related illness should only be used if the person has an AIDS diagnosis.

AIDS Response: The terms AIDS response, HIV response, response to AIDS, and response to HIV are often used interchangeably to mean the response to the epidemic. AIDS Virus: Since AIDS is a syndrome, it is incorrect to refer to the virus as the AIDS virus. HIV (the human immunodeficiency virus) is what ultimately causes AIDS (acquired immunodeficiency syndrome). In referring to the virus, it is preferable to write the full expression or use HIV; avoid the term HIV virus.

$A R T$ : Best spelt out in full as antiretroviral therapy or antiretroviral treatment. Currently, antiretroviral drugs (ARVs) slow down replication of the virus and can greatly enhance quality of life, but they do not eliminate HIV infection. 
Beast Syndrome (BS): The fear that the Beast of bible prophecy (Dan 7 and Rev 13-14), through his sophistry and craft, may beguile the church from her fidelity to God, and that the SDA church should, therefore, ever be skeptical of any dealings whatsoever with any organizations which are not SDA-religious or political.

Behavior Change (not Behavioural Change): There are a number of theories and models of human behavior that guide health promotion and education efforts to encourage behavior change, i.e., the adoption and maintenance of healthy behaviors.

Client-Initiated Testing: Alternative term for voluntary counseling and testing (VCT). All HIV testing must be carried out under conditions of the 3Cs: counseling, confidentiality, and informed consent.

Commercial Sex Work: Preferred terms are commercial sex and the sale of sexual services.

Compassion Factor: A term used to refer to the place of compassion in the fight against HIV/AIDS.

Co-Sponsors: The Joint United Nations Programme on HIV/AIDS (UNAIDS) has the following ten Cosponsors, listed below:

1. The United Nations High Commissioner for Refugees (UNHCR) http://www.unher.ch

2. The United Nations Children's Fund (UNICEF) (http://www.unicef.org/)

3. The World Food Programme (WFP) (http://www.wfp.org)

4. The United Nations Development Programme (UNDP) (http://www.undp.org/)

5. The United Nations Population Fund (UNFPA) (http://www.unfpa.org/) 
6. The United Nations Office on Drugs and Crime (UNODC) (http://www. unodc.org/odccp/index.html)

7. The International Labour Organization (ILO) (http://www.ilo.org/)

8. The United Nations Educational, Scientific and Cultural Organization (UNESCO) (http://www.unesco.org/)

9. The World Health Organization (WHO) (http://www.who.int/en/)

10. The World Bank (http://www.worldbank.org).

Describing AIDS: AIDS is often referred to as a deadly, incurable disease, but this creates a lot of fear and only serves to increase stigma and discrimination. It has also been referred to as a 'manageable, chronic UNAIDS illness, much like hypertension or diabetes', but this may lead people to believe that it is not as serious as they thought. It is preferable to use the following description: AIDS is a fatal disease caused by HIV, the human immunodeficiency virus. HIV destroys the body's ability to fight off infection and disease, which can ultimately lead to death.

Driver: The term relates to the structural and social factors, such as poverty, gender, and human rights, that are not easily measured and that can increase people's vulnerability to exposure to HIV. It is often reserved for underlying determinants.

Epidemic: In epidemiology, an epidemic is a disease that appears as new cases in a given human population (e.g., everyone in a given geographic area; a university, or similar population unit; or everyone of a certain age or sex, such as the children or women of a region) during a given period, at a rate that greatly exceeds what is expected based on recent experience. Defining an epidemic is subjective, depending in part on what is expected. An epidemic may be restricted to one locale (an outbreak), more 
general (an epidemic) or global (a pandemic). Common diseases that occur at a constant but relatively high rate in the population are said to be endemic. Widely-known examples of epidemics include the plague of mediaeval Europe known as the Black Death, the Influenza Pandemic of 1918-1919, and the current HIV epidemic which is increasingly described as pandemic.

Epidemiology: The branch of medical science that deals with the study of incidence, distribution, determinants of patterns of a disease and its prevention in a population.

Evidence-Informed: This term is preferred to evidence-based in recognition of the fact that several elements may play a role in decision making, only one of which may be evidence; others may include cultural appropriateness, cost, feasibility, and concerns about equity, and so on.

Faith-Based Organizations: Faith-based organization (FBO) is the term preferred instead of Church, Religious Organization, etc. as it is inclusive (non-judgmental about the validity of any expression of faith) and moves away from historical (and typically European) patterns of thought.

Feminization: Referring to the pandemic, feminization is now often used by UNAIDS and others to indicate the increasing impact that the HIV epidemic has on women. It is often linked to the idea that the number of women infected has equaled, or surpassed, the figure for men. Therefore, in this study feminization is not used in its primary sense in English, becoming more feminine, in a characteristic sense to mean affecting more females than men. 
Fight: In this study, fight and other combatant language, e.g., struggle, battle, campaign, war, is used in connection with HIV and AIDS to refer to all the activities done to lessen the incidence and impact of the pandemic. However, it is best to avoid using such words, unless in a direct quotation or the context of the text (possibly a poster or very short publication designed to have high impact) makes it appropriate. Alternatives include: response, measures against, initiative, action, efforts, and programme.

Gay Men: It is best to use the phrase men who have sex with men (MSM) unless individuals or groups specifically self-identify as gay. The broader community of men and women and transsexuals should be described as lesbian, gay, bisexual, and transgendered-the abbreviation LGBT is often used of groups, but UNAIDS' general preference is to spell out all terms in full.

Gender and Sex: The term sex refers to biologically determined differences, whereas the term gender refers to differences in social roles and relations between men and women. Gender roles are learned through socialization and vary widely within and between cultures. Gender roles are also affected by age, class, race, ethnicity; and religion, as well as by geographical, economic, and political environments. Hence, people talk of gender-based violence, for example.

Global Fund: This is the shorter form for The Global Fund to Fight AIDS, Tuberculosis and Malaria (GFATM). Established in 2001, the Global Fund is an independent public-private partnership. It is the largest global fund in the health domain, which by 2005 had already committed over three billion dollars (US) in 128 countries. The purpose of the Global Fund is to attract, manage and disburse additional resources to make a sustainable and significant contribution to mitigate the impact caused by HIV, 
tuberculosis and malaria in countries in need, while contributing to poverty reduction as part of the MDGs.

GIPA: Acronym for the greater involvement of people living with or affected by HIV/AIDS. In 1994, 42 countries prevailed upon the Paris AIDS Summit to include the Greater Involvement of People Living with HIV/AIDS Principle (GIPA) in its final declaration.

High-Risk Groups/Populations with Higher-Risk of Exposure to HIV: These terms should be used with caution as they can increase stigma and discrimination. They may also lull people who don't identify with such groups into a false sense of security. Highrisk group also implies that the risk is contained within the group whereas, in fact, all social groups are interrelated.

It is often more accurate to refer directly to higher risk of HIV exposure, sex without a condom, unprotected sex, or using non-sterile injection equipment rather than to generalize by saying high-risk group. Membership of groups does not place individuals at risk, but behaviors may.

In the case of married and cohabiting people, particularly women, it may be the risk behavior of the sexual partner that places them in a situation of risk. There is a strong link between various kinds of mobility and heightened risk of HIV exposure, depending on the reason for mobility and the extent to which people are removed from their social context and norms.

Highly Active Antiretroviral Therapy (HAART): This is the name given to treatment regimens recommended by leading HIV experts to aggressively suppress viral replication and slow the progress of HIV disease. The usual HAART regimen combines 
three or more different drugs such as two nucleoside reverse transcriptase inhibitors and a protease inhibitor, two NRTIs (nucleoside reverse transcriptase inhibitors), and a nonnucleoside reverse transcriptase inhibitor or other combinations.

More recently, a new drug has been developed to prevent the virus from entering the cell. These treatment regimens have been shown to reduce the amount of virus so that it becomes undetectable in a patient's blood. The term ART can be used if it clearly refers to a triple antiretroviral drug combination.

HIV-Related Disease: Symptoms of HIV-infection may occur both at the beginning of HIV infection and after immune compromise sets in, leading to AIDS. During the initial infection with HIV, when the virus comes into contact with the mucosal surface, it finds susceptible target cells and moves to lymphoid tissue where massive production of the virus ensues. This leads to high-level virus presence in the bloodstream with wide dissemination of the virus. Some people may have flu-like symptoms at this stage but these are generally referred to as symptoms of primary infection rather than HIV-related disease. The resulting immune response to suppress the virus is only partially successful and some virus escapes and may remain undetectable for months to years. Eventually high viral turnover leads to destruction of the immune system, sometimes referred to as advanced HIV infection.

HIV disease is, therefore, characterized by a gradual deterioration of immune function. During the course of infection, crucial immune cells, called CD4+ T cells, are disabled and killed, and their numbers progressively decline.

HIV-Infected: As distinct from HIV-positive (which can sometimes be a false positive test result, especially in infants of up to 18 months of age), the term HIV- 
infected is usually used to indicate that evidence of HIV has been found via a blood or tissue test.

HIV-Negative: Showing no evidence of infection with HIV (e.g., absence of antibodies against HIV) in a blood or tissue test. This term is synonymous with seronegative. An HIV-negative person can be infected if he or she is in the window period between HIV exposure and detection of antibodies.

HIV-Positive: Showing indications of infection with HIV (e.g., presence of antibodies against HIV) on a test of blood or tissue. This term is synonymous with seropositive. However, it is important to caution that a test may occasionally show false positive results.

Human Immunodeficiency Virus (HIV): The virus that weakens the immune system, ultimately leading to AIDS. Since HIV means human immuno-deficiency virus, it is redundant to refer to the HIV virus. But, is HIV the same as AIDS? Many people are confused about these two terms. However, as Berkow, Beers, Bogin, and Fletcher (1997) rightly point out, though related and often used interchangeably, the two are not the same. HIV is an acronym for human immunodeficiency virus, the virus which causes AIDS while AIDS is condition in which the natural body immunity to disease is compromised, leading to the onset of numerous opportunistic ailments (p. 92).

It may be proper at this juncture to point out that there is usually some confusion on the use of the terms HIV and AIDS; should we combine the terms as HIV/AIDS, or should they be separated as simply HIV and AIDS? Uncertainty prevails over this issue in the literature. However, according to UNAIDS, it is best to Use HIV unless specifically referring to AIDS. Examples include people living with HIV (PLHIV), the 
HIV epidemic, HIV prevalence, HIV prevention, HIV testing, HIV-related disease; AIDS diagnosis, children made vulnerable by AIDS, children orphaned by AIDS, the AIDS response. Both HIV epidemic and AIDS epidemic are acceptable.

Human Immunodeficiency Virus HIV/AIDS TYPE 1 (HIV-1): The retrovirus isolated and recognized as the etiologic (i.e., causing or contributing to the cause of a disease) agent of AIDS. HIV-1 is classified as a lentivirus in a subgroup of retroviruses. Most viruses and all bacteria, plants, and animals have genetic codes made up of DNA, which uses RNA to build specific proteins. The genetic material of a retrovirus such as HIV is the RNA itself. HIV inserts its own RNA into the host cell's DNA, preventing the host cell from carrying out its natural functions and turning it into an HIV factory.

Human Immunodeficiency Virus Type $2(H I V-2)$ : This is a virus closely related to HIV-1 that has also been found to cause AIDS. It was first isolated in West Africa. Although HIV-1 and HIV-2 are similar in their viral structure, modes of transmission, and resulting opportunistic infections, they have differed in their geographical patterns of infection and in their propensity to progress to illness and death. Compared to HIV-1, HIV-2 is found primarily in West Africa and has a slower, less severe clinical course.

ILO: The International Labor Organization is one of UNAIDS' ten Cosponsors Incidence: $H I V$ incidence (sometimes referred to as cumulative incidence) is the proportion of people who have become infected with HIV during a specified period of time. UNAIDS normally refers to the number of people (of all ages) or children (0-14) who have become infected during the past year.

The word incidence is often confused with prevalence. However, while HIV prevalence refers to the number of infections at a particular point in time (like a camera 
snapshot), the term incidence rate is used to describe incidence per hundred person years of observation. This especially applies to specific observational studies and prevention trials.

Injecting Drug Users (IDUs): This term is preferable to drug addicts or drug abusers, which are seen as derogatory and which often result in alienation rather than creating the trust and respect required when dealing with those who inject drugs. UNAIDS does not use the term intravenous drug users because subcutaneous and intramuscular routes may be involved. It is preferable to spell out in full and not use the abbreviation.

Intervention: This term conveys doing something to someone or something, and as such undermines the concept of participatory responses. Preferred terms include programming, programme, activities, initiatives, etc.

Millennium Development Goals (MDGs): Eight goals developed at the Millennium Summit in September 2000. Goal six refers specifically to AIDS but attainment of several goals is being hampered by the HIV epidemic.

Monitoring and Evaluation: Monitoring and evaluation of the response to the epidemic.

MSM: Abbreviation for men who have sex with men or males who have sex with males. This term is useful as it includes not only men who self identify as gay or homosexual and have sex only with other men but also bisexual men, and heterosexual men who may, nonetheless at times have sex with other men.

MTCT: Abbreviation for mother-to-child transmission (pMTCT is the abbreviation for prevention of mother-to-child transmission). Some countries prefer the 
term parent-to-child transmission (PTCT) to avoid stigmatizing pregnant women and to encourage male involvement in HIV prevention.

$N A C$ : National AIDS Coordinating Authority (formerly National AIDS Council): the acronym should generally be avoided. This is the body in each country that coordinates all HIV and AIDS activities.

Opportunistic Infections: Otherwise referred to as HIV disease, the phrase refers to illnesses caused by various organisms, some of which usually do not cause disease in persons with healthy immune systems. Persons living with advanced HIV infection may suffer opportunistic infections of the lungs, brain, eyes and other organs. Opportunistic illnesses common in persons diagnosed with AIDS include pneumonia, cryptosporidiosis, and other parasitic, viral and fungal infections, and some types of cancers. Others include malaria, TB, and diarrhea.

Orphans: In the context of AIDS, it is preferable to say children orphaned by AIDS or orphans and other children made vulnerable by AIDS. However, it is necessary to point out here that referring to these children as AIDS orphans not only stigmatizes them, but also labels them as HIV-positive, which they may not necessarily be. Identifying a human being by his/her medical condition alone also shows a lack of respect for the individual.

OVC: Orphaned and vulnerable children. While children are generally very vulnerable, being orphaned makes them more vulnerable. However, contrary to traditional usage UNAIDS uses orphan to describe a child that has lost either one or both parents. 
Pandemic: A disease prevalent throughout an entire country, continent, or the whole world. Preferred usage is to write pandemic when referring to global disease and to use epidemic when referring to country or regional level. For simplicity, UNAIDS often uses epidemic, see epidemic.

Pathogen: An agent causing disease.

People Living with HIV (PLWH): It is better to avoid the expressions people living with HIV and people living with HIV and AIDS (PLWHA). Also, with reference to those living with HIV, it is more preferable to avoid certain terms: AIDS patient should only be used in a medical context (most of the time, a person with AIDS is not in the role of patient); the term AIDS victim or AIDS sufferer implies that the individual in question is powerless, with no control over his or her life. It is preferable to use PLHIV for people living with HIV, since this reflects the fact that an infected person may continue to live well and productively for many years. This document also uses PLWA for people living with AIDS.

Referring to PLHIV as innocent victims (which is often used to describe HIVpositive children or people who have acquired HIV medically) wrongly implies that people infected in other ways are somehow deserving of punishment. Therefore, it is preferable to use PLHIV, or children with HIV.

PEPFAR: The U.S. President's Emergency Plan for AIDS Relief announced by President George W. Bush in his State of the Union Address 28 January 2003. The plan was to develop a five-year 15 billion dollar (US) initiative aimed at turning the tide in combating the global HIV/AIDS pandemic. 
Prevalence: Usually given as a percentage, HIV prevalence quantifies the proportion of individuals in a population who have HIV at a specific point in time. HIV prevalence is usually measured among adults aged between 15 to 49 years. The practice is not say prevalence rates because a time period of observation is not involved.

Prostitution: This term is used in respect to juvenile prostitution. Otherwise, for people of older ages it is more preferable to use the terms commercial sex or the sale of sexual services.

Provider-Initiated Testing: Under certain circumstances, when an individual is seeking medical care, HIV testing may be offered. It may be diagnostic - patient presents with symptoms that may be attributable to HIV or has an illness associated with HIV such as tuberculosis - or it may be a routine offer to an asymptomatic person. For example, HIV testing may be offered as part of the clinical evaluation of patients with sexually transmitted infections and pregnant women. HIV testing may be offered to all patients where HIV is prevalent. Regardless of the type of testing and the location of the offer, all HIV testing should always be carried out under conditions respecting $3 \mathrm{Cs}-$ confidentiality, informed consent and counseling. Testing without counseling has little impact on behavior and is a significant lost opportunity for assisting people to avoid acquiring or transmitting infection.

PTCT: Parent-to-child transmission, a term preferred in some countries as it is perceived to be less stigmatizing to mothers (see MTCT).

Risk: It is better to avoid using the expressions groups at risk or risk groups. People with behaviors which may place them at higher risk of exposure to HIV do not necessarily identify themselves with any particular group. Risk refers to risk of exposure 
to HIV which may be high as a result of specific behaviors or situations. Examples of the latter include risk in discordant couples unaware of their serostatus and recipients of unscreened blood or blood products. Behaviors, not memberships, place individuals in situations in which they may be exposed to HIV. Some populations may be at increased risk of exposure to HIV.

Risk Compensation or Risk Enhancement: A compensatory increase in behaviors which can result in exposure to HIV brought on by reduced perception of personal risk, e.g., uptake of a $50 \%$ effective preventive HIV vaccine might tend to encourage abandoning condom use.

Safe Sex: The term safer sex more accurately reflects the idea that choices can be made and behaviors adopted to reduce or minimise risk. It is more preferable to use the term safer sex because safe sex may imply complete safety. Sex is $100 \%$ safe from HIV transmission when both partners know their HIV-negative serostatus and neither partner is in the window period between HIV exposure and appearance of HIV antibodies detectable by the HIV test. In other circumstances, reduction in the numbers of sexual partners and correct and consistent use of male or female condoms can reduce the risk of HIV transmission.

Scale Up: When used as a verb, scale-up, or scaling-up when used as a noun is the term used when referring to efforts made to expand the fight against HIV/AIDS.

$S D A$ : This acronym stands for Seventh-day Adventist Church. Sometimes the shorter form Adventists is used.

Seroprevalence: As related to HIV infection, the proportion of persons who have serologic evidence of HIV infection, i.e., antibodies to HIV at any given time. 
Serostatus: A generic term that refers to the presence/absence of antibodies in the blood. Often, the term refers to HIV antibody status.

SESDA_AIDS: An acronym for Strategy to engage Seventh-day Adventists in the fight against HIV/AIDS, the strategy proposed as a result of this study.

Sexually Transmitted Infection (STI): Also called venereal disease (VD), an older public health term, or sexually transmitted diseases (STDs), a term that does not convey the concept of asymptomatic sexually transmitted infections.

Sexually transmitted infections are spread by the transfer of organisms from person to person during sexual contact. In addition to the traditional STIs (syphilis and gonorrhoea), the spectrum of STIs now includes HIV, which causes AIDS; Chlamydia trachomatis; human papilloma virus (HPV) which can cause cervical or anal cancer; genital herpes; chancroid; genital mycoplasmas; hepatitis B; trichomoniasis; enteric infections; and ectoparasitic diseases (i.e., diseases caused by organisms that live on the outside of the host's body). The complexity and scope of sexually transmitted infections have increased dramatically since the 1980 s to the extent that more than 20 organisms and syndromes are now recognized as belonging in this category.

Sex Work: Commercial sex work is considered a tautology, which is saying the same thing twice over in different words. Preferred terms are sex work, commercial sex, and the sale of sexual services.

Sex Worker: The term sex worker is intended to be non-judgmental, focusing on the conditions under which sexual services are sold. Alternate formulations are women/men/people who sell sex. Clients of sex workers may then also be called $\mathrm{men} /$ women/people who buy sex. The term commercial sex worker is no longer used, 
primarily because it is considered to be saying something twice over in different words (i.e., a tautology).

Sharing: When referring to injecting equipment it is now more preferable not to use the word sharing. Instead, it is better to refer to use of contaminated injecting equipment if you are considering HIV transmission and use of non-sterile injecting equipment when considering risk of HIV exposure. This is because injecting drug users uncommonly share their needles in the usually understood sense of the word-with the exception of sexual partners who inject together. In the absence of needle exchanges, people may use discarded needles (which are anonymous), or bargain away drugs for a needle or are injected by professional injectors. They do not regard this as sharing. Neither does sharing distinguish between needle borrowing and needle lending; this is important because (usually) different dynamics are at work. A person aware of his or her HIV-positive status may try to avoid lending, but may continue to borrow or vice versa. Also sharing has positive connotations, e.g., sharing a meal in injecting drug use communities (and wider communities also) which are not appropriate in writing about HIV risk.

Stigma and Discrimination: As the traditional meaning of stigma is a mark or sign of disgrace or discredit, the correct term would be stigmatization and discrimination; however, stigma and discrimination has been accepted in everyday speech and writing, and may be treated as plural.

Surveillance: Continuous analysis, interpretation, and feedback of systematically collected data, generally using methods distinguished by their practicality, uniformity, and rapidity rather than by accuracy or completeness. 
Target: This term is acceptable as a noun referring to an objective or goal. Avoid using as a verb for example targeting $M S M$ as this conveys non-participatory, top-down approaches. Preferred alternative terms include: programs for and by MSM; faengaging MSM in programming; and programs involving MSM in the response to the epidemic, etc.

Testing: HIV testing is pivotal to both prevention and treatment interventions. The 3Cs continue to be underpinning principles for the conduct of all HIV testing of individuals; testing must be confidential, accompanied by counseling, and only be conducted with informed consent, meaning that it is both informed and voluntary.

3 by 5 Initiative: Always cite in this form, with double quotation marks. 3 by 5 was a UNAIDS and WHO global initiative to provide antiretroviral therapy to three million PLHIV in low- and middle-income countries by the end of the year 2005

Three Ones principles: Always use in this form Three Ones principles, with double quotation marks. The principles are one agreed HIV/AIDS Action Framework that provides the basis for coordinating the work of all partners; one National AIDS Coordinating Authority, with a broad-based multisectoral mandate; and one agreed country-level Monitoring and Evaluation System.

Universal Access: This phrase is commonly used to refer to the goal to provide universal access (not capitalized) to HIV prevention, treatment, care and support. This initiative is outlined in the 2006 Political Declaration on HIV/AIDS.

VCT: Abbreviation for voluntary counseling and testing. It is also known as client-initiated testing and is used in contrast to provider-initiated testing. But all testing should be conducted in an environment which adheres to and implements the 3Cs. 
Vertical Transmission: Sometimes used to indicate transmission of a pathogen such as HIV from mother to fetus or baby during pregnancy or birth but may be used to refer to the genetic transmission of traits.

\section{Methodology}

The methodology adopted for this study included an examination of five passages from the Gospels that depict Jesus' interaction with people who were suffering. Such an investigation could lay the theological foundation for the involvement of Christians in fighting the HIV and AIDS pandemic. Then, a survey of literature on the AIDS pandemic was done in order to establish the major issues in HIV mitigation. Following that a survey designed around a descriptive and exploratory social research model utilizing quantitative and quantitative research techniques for data collection and analysis was carried out. By means of self-structured questionnaires, members of two SDA churches in Lusaka were surveyed regarding the involvement of the SDA Church in the fight against HIV/AIDS. Finally, based on the results of Chapter 4 , Chapter 5 proposes a strategy by which to engage SDA members in the fight against the pandemic.

\section{Conclusion}

In summary, this chapter has drawn attention to the HIV/AIDS situation in Lusaka, the Capital city of Zambia, which has reached crisis proportions. In the city are more than 85,000 SDA churches members who are practically uninvolved in the fight against the pandemic. For a church that is well known for its involvement in issues affecting society exemplified by the hospitals and schools that it operates around the globe, this situation is both puzzling and regrettable. The methodology of the project has been presented. 
The next chapter examines the life and ministry of Jesus, the prime example for all believers, for any clues as to how best to relate to the untold suffering in which we find ourselves today. 


\section{CHAPTER 2}

\section{THE THEOLOGICAL FOUNDATION FOR CHRISTIAN \\ INVOLVEMENT IN THE FIGHT AGAINST HIV/AIDS}

\section{Introduction}

As the world continues to grapple with the sad and frightening reality of the HIV pandemic with its burden of suffering and misery, those involved in the fight against the scourge are already lamenting a shortage of leadership and human compassion which they feel is needed before any sustainable results in the fight against the pandemic can be achieved (UNAIDS, 2006a, p. 6). The implication is clearly that there is an urgent and critical need for leadership and compassion to be brought in if we are to win the fight against HIV/AIDS against the pandemic.

The place of the compassion factor in the fight against HIV/AIDS which UNAIDS (UNAIDS, 2006a, p. 3) is was calling for cannot be overemphasized considering that the financial resources available for the fight against HIV/AIDS are limited and some of the major sponsors of the HIV pandemic fight are beginning to reduce funding. However, whether there is enough money or not, removing compassion from the fight against the pandemic leaves the effort under the control of very destructive factors such as the love of money and the search for political power. Those involved in the fight against so critical a humanitarian issue as AIDS should be propelled by a motive higher than fiduciary gain. 
Faced with the uncertainty caused by HIV/AIDS, many people are looking for answers in very unseemly sources such as witchcraft. Unfortunately, some are even turning to witch finders for answers. Colson observed this phenomenon among the Tonga of the Gwembe valley in Southern Zambia $(2005$, p. 6). She concluded: "Undoubtedly patronage of witch finders and conversion to Christianity are responses to the increased insecurity of Zambian life in which AIDS plays a part" (p. 7). But, as Colson readily admits and points out, it would be difficult to demonstrate that either the rise of witchcraft or the rise in conversions to Christianity is a direct response to the AIDS epidemic.

At the same time, many others are turning to religion for answers. Many people today are asking questions, such as, What does the Bible say about HIV/AIDS? How does God regard people suffering from this disease, or other diseases? Often, the questioning goes further to include the duty of Christians in such a crisis. Indeed, in the face of so much human suffering should Christians just engage in preaching the Word of God, in order to hasten the day when the Son of Man will come again to put an end to all suffering? Or, should they also work to mitigate or end the suffering going on around them? In short, how should Christians relate to human suffering today? These are critical questions which deserve honest answers.

This chapter attempts to lay a theological basis for Christian involvement in the fight against the HIV/AIDS crisis presently ravaging the world. Needless to say, how Christians are going to respond to the HIV pandemic and the unprecedented suffering the disease has brought depends on how the Church will answer theological questions relating to its meaning and existence. And, whether Christianity will remain credible and 
relevant to humanity at this critical moment in history may well depend on how the Church responds to the human suffering the HIV/SAIDS caused by the pandemic.

But, what is compassion? Why was it so important to Jesus? Perhaps, the reasons why all believers should be total involvement in alleviating human suffering if given a clearer understanding of compassion itself. To this subject, we turn next.

\section{Compassion: The Springboard of Jesus' Ministry}

The survey of texts done earlier in the chapter identified compassion as a common thread that runs through the ministry of Jesus. Compassion moved Jesus to heal and alleviate human suffering. What is compassion? Why is it important in life? What does it mean, especially for the believer? Why was compassion the driving force behind everything Jesus did or taught?

\section{Compassion in the Old Testament}

Several words in both the Old Testament and the New Testament are translated as compassion. In the Old Testament, compassion is the translation of racham, which is also rendered as 'to love,' 'pity,' 'be merciful.' Racham, (to have compassion, be merciful, pity) is the verb form of the root, and the words from this root are found 125 times in all parts of the Old Testament (Vine, Unger, \& White, 1985). The verb is translated 'love' once: "I will love thee, O Lord" (Ps 18:1). Racham is also used in God's promise to declare His name to Moses: "I will make all my goodness pass before thee, and I will proclaim the name of the Lord before thee; and will be gracious to whom I will be gracious, and will show mercy on whom I will show mercy" (Exod 33:19). Therefore, men were taught to pray: "Remember, O Lord, thy tender mercies and thy lovingkindnesses" (Ps 25:6). Isaiah prophesies messianic restoration: "with great mercies will I 
gather thee. . . But with everlasting kindness will I have mercy on thee, saith the Lord thy Redeemer" (Isa 54:7-8).

According to W. E. Vine, M. F. Unger, and W. White Jr. (1985), the noun form rechem may be rendered as 'bowels, womb, mercy.' The first use of rechem is in its primary meaning of 'womb': "The Lord had fast closed up all the wombs of the house of Abimelech" (Gen 20:18). In a figurative sense, the KJV reads in $1 \mathrm{Kgs} \mathrm{3:26:} \mathrm{"Her} \mathrm{bowels}$ yearned upon her son," which the NIV translates more idiomatically: "[She] was filled with compassion for her son." The greatest frequency is in this figurative sense of "tender love,' such as a mother has for the child she has borne.

As Vine, Unger, and White (1985) correctly point out, the other noun form of the word, rachamim, is also rendered 'bowels, mercies, compassion.' This noun, always used in the plural intensive, occurs in Gen 43:14: "And God Almighty give you mercy"; where the NASB renders it as “compassion." In Gen 43:30, it is used of Joseph's feelings toward Benjamin: "His bowels did yearn upon his brother" (NIV). "He was deeply moved at the sight of his brother." Rachamim is most often used of God, as by David in 2 Sam 24:14: "Let us fall now into the hand of the Lord; for his mercies are great." We have the equivalent Aramaic word in Daniel's request to his friends: "That they would desire mercies of the God of heaven concerning this secret" (Dan 2:18).

\section{Compassion in the New Testament}

A number of other Greek words in the New Testament are translated 'compassion' or any of its near equivalents like 'pity,' 'mercy,' etc. Splanchnizonai is translated 'compassion' in Matt 9:36. Then there is sumpatheo (Heb 10:34), "to suffer with (another)"; sumpathes (1 Pet 3:8, the Revised Version [British and American] 
'compassionate,' margin, Greek, 'sympathetic'); metriopatheo (Heb 5:2, the Revised Version [British and American] "who can bear gently with"); eleeo, 'to show mildness,' 'kindness' (Matt 18:33; Mark 5:19; Jude v. 22, the Revised Version [British and American] 'mercy'); oikteiro, 'to have pity' or 'mercy' (Rom 9:15 twice).

Another, oikteiro, or, 'to have pity, a feeling of distress through the ills of others,' is used of God's compassion, (Rom 9:15). Sumpatheo "to suffer with another (sun, 'with,' pascho, 'to suffer'), to be affected similarly" (Eng., 'sympathy'), to have 'compassion' upon, Heb 10:34, of 'compassionating' those in prison, is translated 'be touched with' in Heb 4:15, of Christ as the High Priest. On the other hand, eleeo, "to have mercy (eleos, 'mercy'), to show kindness, by beneficence, or assistance," is translated "have compassion" in Matt 18:33 (KJV); Mark 5:19 and Jude 22. Finally, metriopatheo is rendered 'have compassion,' in Heb 5:2, KJV (Vine, Unger, \& White, 1985).

However, of all the Greek words for compassion used in the New Testament, splanchnizonai, (which literary means, "to have the bowel yearning;" "to be moved as to one's inwards parts [solanchna];" or "to be moved with compassion; to yearn with compassion"), is the most prevalent. Splanchnizonai is used 12 times in the Gospels: 5 times by Matthew, 4 times by Mark and 3 more times by Luke, in each case referring to compassion (Young, 1977).

Splangchnizomai, 'to be moved as to one's inwards (splanchna), to be moved with compassion, to yearn with compassion,' is frequently recorded of Christ towards the multitude and towards individual sufferers, Matt 9:36; 14:14; 15:32; 18:27; 20:34; Mark $1: 41 ; 6: 34 ; 8: 2 ; 9: 22$ (of the appeal of a father for a demon-possessed son); Luke 7:13; 
10:33; of the father in the parable of the Prodigal Son, 15:20. And Esplangchnisthee ('moved with compassion') is derived from splangchnon, which means 'a bowel.'

According to W. L. Walker (1996), racham and splagchnizomai are examples of the physical origin of spiritual terms, the bowels being regarded as the seat of the warm, tender emotions or feelings. But, while racham applied to the lower viscera as well as the higher, splagchnon denoted chiefly the higher viscera, the heart, lungs, liver. The Jews esteemed the bowels to be the seat of sympathy and the tender passions, and so applied the organ to the sense. This verb is believed to have been coined during the Jewish dispersion - a time when the Jews experienced a lot of mental anguish and physical suffering (n.p.).

Splangchnizomai signifies 'to be moved with pity from the very inmost bowels.' It is an emphatic word, signifying a vehement affection of commiseration, by which the bowels and especially the heart is moved. Both this verb and the noun seem to be derived from spaoo, 'to draw'; the whole intestinal canal, in the peristaltic motion of the bowels, being drawn, affected, and agitated with the sight of a distressed or miserable object. Pity increases this motion of the bowels, and produces considerable pain; hence, splangchnizomai, to have the bowels moved, signifies to feel pity or compassion at seeing the miseries of others.

Thus, commenting on the use of eusplagchnos in Eph 4:32, where it is rendered "compassionate," "tenderhearted," the Seventh-day Adventist Bible Commentary fittingly concludes that "a callous indifference to the suffering is wholly incompatible with the Christian spirit" ("Ephesians: Chapter 4," 1980, p. 1029). And, based on Col 3:12, where the same word is rendered "tender mercies," the same authority notes that the word there 
means "a tender regard for the weaknesses and needs of others;" and concludes that, therefore, "a heart of compassion is a distinguishing feature of true Christianity" (“Colossians: Chapter 3," 1980, p.212).

The Significance of Compassion to Hebrew Faith

As may be evident from the foregoing, compassion was a common aspect of Jewish faith both during the old and new dispensations. Literally meaning 'a feeling with and for others,' compassion is a fundamental and distinctive quality of the biblical conception of God, and lay at the very centre of Hebrew life and faith. First, it lay at the foundation of Israel's faith in Yahweh. For it was out of His compassion that He, by a marvelous act of power, delivered them from Egyptian bondage and called them to be His own people. Nothing, therefore, is more prominent in the Old Testament than the ascription of compassion, pity, or mercy to God; and children of Israel are said to have gloried the fact that their God was a God of mercy. This is evident from such sayings as the great declaration in Exod 34:6: "Yahweh-a God full of compassion (the American Standard Revised Version merciful) and gracious" (compare Pss 78:38; 86:15; 111:4; 112:4; 145:8; Lam 3:22, "His compassions fail not"). And, because this was the character of their God, the prophets declared that compassion was an essential requirement on the part of members of the community (Hos 6:6; Mic 6:8; compare Prov 19:17).

As Bible Soft (2000) aptly suggests, compassion, or mercy, is the aspect of God's love that causes Him to help the miserable, just as grace is the aspect of His love that moves Him to forgive the guilty. And, it is important to add that God shows mercy without regard to whether those in misery may be suffering as a result of breaking God's law or because of circumstances beyond their control, because as Daniel shows God 
shows mercy upon those who have broken His law (Dan 9:9; 1 Tim 1:13,16). However, such mercy was selective, demonstrating that it is not deserved (Rom 9:14-18). Even in the New Testament, God shows mercy by actively helping those who are miserable due to circumstances beyond their control. We see this aspect of mercy especially in the life of our Lord Jesus. He healed blind men (Matt 9:27-31; 20:29-34) and lepers (Luke 17:1119). These acts of healing grew out of his attitude of compassion and mercy.

Finally, because God is merciful, He expects His children to be merciful (Matt $5: 7 ; 25: 39,45 ;$ Jas $1: 27)$.

Compassion was, in Jesus Christ, the one in whom God was "manifest in the flesh," an outstanding feature (e.g., Matt 9:36; 14:14) and He taught that it ought to be extended, not to friends and neighbors only, but to all without exception, even to enemies (Matt 5:43-48; Luke 10:30-37).

The God of the New Testament, the Father of men, is most clearly revealed as "a God full of compassion." This compassion is extended to the whole human race, for which He effected not merely a temporal but a spiritual and eternal deliverance, giving up His own Son to the death of the cross in order to save the human race from the worst bondage of sin, with its consequences; seeking thereby to gain a new, wider people for Himself, still more devoted, more filled with and expressive of His own Spirit. Therefore, all who know the God and Father of Christ, and who call themselves His children, must necessarily cultivate compassion and show mercy, "even as he is merciful." That is why the New Testament contains many apostolic injunctions to that effect (Eph 4:32; Col $3: 12$; Jas $1: 27 ; 1$ John $3: 17$, etc.). For this reason, we concur with Walker (as cited in 
Booth, 2009) that ultimately, "Christianity may be said to be distinctively the religion of Compassion" (p. 8).

Thus, a close investigation of compassion in the Bible not only leads to the firm view that it was the driving force behind all that Jesus did or taught, but also establishes that it was at the very centre of Hebrew life and faith. Compassion was not just the basis of Israel's relationship with their God, upon whose mercy or compassion alone they could bank for forgiveness and acceptance. They also needed to cultivate this grace, by God's help, and reflect it towards one another.

\section{Jesus' Attitude Toward Suffering}

During His three and a half years of ministry Jesus healed many people suffering from different diseases and taught many lessons regarding suffering. These encounters and lessons are instructive for Christians on how to relate to those suffering around them in their time. According to one Bible commentator, Jesus spent more time healing the sick than preaching or teaching:

The Lord Jesus is our example. He came to the world as a servant of mankind. He went from city to city, from village to village, teaching the gospel of the kingdom, and healing the sick. Christ spent more time in healing than in teaching. (White, 1908, p. 10)

Therefore, in order for Christians to know how to relate to people who are suffering today (HIV/AIDS included), they need to study the life and teachings of Jesus.

The theological reflection in this chapter looks at the teachings and example of Jesus as set forth in Scripture. Five selected passages are briefly reviewed, following which the study focuses on compassion, which seems to be the common element in all Jesus' teachings and miracles of healing. Thereafter follows a summary of the principles 
that emerge from Jesus' ministry. These principles are to be used as a guide to Christians on whether or not and how to relate to the current HIV/AIDS crisis.

While the Scriptures contain many passages where Jesus came into contact with people experiencing suffering, this chapter focuses on only five: namely, the healing of the leper (Mark 1:40-45), the healing of the invalid man by the pool of Bethesda (John 5:1-16), the paralytic at Capernaum (Luke 5:17-26), the parable of the Good Samaritan (Luke 10:30-37), and the parable of the Final Judgment (Matt 25:31-37).

The Healing of a Man Suffering From Leprosy

The Gospel of Mark records the story of a leper who came to Jesus with the plea, "If you want to, you can make me clean" (Mark 1:40-45). It is significant that the apostle Mark records that Jesus healed the man having been "moved with compassion" (v. 41). And, indeed, it is actually hard for one to read the account without feeling the compassionate touch in the story. MacDonald (2005) suggests that Jesus' answer to the leper: "I am willing," shows that Jesus "is more willing to heal than we are to be healed" (p. 1323), perhaps on the basis that the leper was not sure that Jesus was willing to heal him.

It is also noteworthy that commentators do not suggest the leper brought the disease upon himself. This is important because in scripture leprosy is used to represent sin. By implication, all human beings are born sinners, and the solution to the sin problem can only be found in God. Thus, Ellen White (1940) speaks of "the leprosy of sin-deeprooted, deadly, and impossible to be cleansed by human power" (p. 266). 
What we see here is that for diseases such as leprosy, whose cause was outside an individual's actions, Jesus was present to heal. In other words, Jesus showed compassion for illnesses which were not self-inflicted, as in the leper's case.

The Healing of the Paralytic Man

The healing of the paralytic, who was brought before Jesus through the roof in Capernaum, is recorded by Matthew (9:1-8) Mark (2:1-12) and Luke (5:17-26). A great crowd had gathered at a certain house in Capernaum to listen to Jesus. So crowded was it that it was virtually impossible for a group of people who wanted to bring a paralytic colleague of theirs to Jesus to be healed to do so. Undaunted, however, they decided to make an opening through the roof and let the sick man down right, in front of Jesus. The Gospel writers record that when Jesus saw their faith, He said to the paralytic: "Son, your sins are forgiven you" (Mark 2:5). Of course that led the Pharisees to accuse Jesus of blasphemy.

What does this miracle teach us about Jesus' compassion? Ellen White suggests that, this man, unlike the leper in the story referred to example above, had brought the illness upon himself. According to Ellen White (1940) the man's disease was "the result of a life of sin, and his sufferings were embittered by remorse" (p. 267). But, if the man had brought the disease upon himself why did Jesus show deep compassion for him? Should Jesus not have reserved His compassion for a more deserving case? Or, does Jesus' behavior here suggest that compassion has nothing to do with how one acquires an illness? Despite such concerns which are very normal for us today, the fact is that Jesus healed a man who had brought disease upon himself. 
There is no doubt that this story illustrates our loving Savior's compassion towards sickness and suffering without regard to a person's behaviors that may have resulted in the disease.

The Healing of the Man by the Pool of Bethesda

Only the Apostle John records the story of the cripple by the pool of Bethesda (John 5:1-16). It was believed in those days that at a certain time of the year an angel of God would pass by the pool and stir up the waters. Then, whoever among the sick people would manage to get into the water ahead of the others would get well.

It was with this hope that a certain man whom Jesus came across one Sabbath cherished. The Bible tells us that the man had been sick 38 years and had come to try his luck, but in vain; because, apparently the men that brought him there either got tired of waiting or simply left.

To this man, who was helplessly lying on his couch with no one to help him get into the water, Jesus put forward the question: "Do you want to be made well?" (John 5:6). But, instead of responding as expected, the man told Jesus that he did not have anyone to put him into the water. Jesus' response was an unequivocal command: "Rise, take up your bed and walk" (v. 8).

Although the word compassion is not used anywhere in this story, there is no doubt that it was compassion that led Jesus to heal the man. And MacDonald (1990) perceptively observes that since the man had been in that condition for over 38 years, he had been in that condition even before Jesus was born (p. 1490). Surely, our compassionate Savior must have been touched by that man's helpless condition and 
desperate situation. Thus, MacDonald (1990) is correct when he concludes that it was "in loving compassion" that Jesus said to him, 'Do you want to be made well?' (p. 1490).

But what was the cause of the man's condition? Before we turn to secondary sources for an answer, the Scriptures themselves give us the answer. In the story, we are told that later in the day, the now healed man met Jesus in the Temple. John describes the encounter thus: "Afterward Jesus findeth him in the temple, and said unto him, Behold, thou art made whole: sin no more, lest a worse thing come unto thee. The man departed, and told the Jews that it was Jesus, which had made him whole" (5:14-15 KJV).

Two facts emerge from the account. First, that Jesus healed a man who did not even know Him and, second, that the man's sickness was caused by his own life of sin. Again, we find Jesus healing a man even though He knew deep down in His heart that the man had brought the sickness and suffering upon himself.

Secondary sources also support this view. According to Ellen White (1940), this man's case was similar to that of the paralytic brought before Jesus through the roof in Capernaum (Luke 5:17-26) in that it as a case of "supreme wretchedness" and "the result of his [the man's] own sin." For that reason, the Jews regarded the illness as "a judgment from God" (p. 202). Nonetheless, though uninvited, Jesus went out to heal the man-and on Sabbath for that matter! That was how Jesus showed compassion-without exceptions. Therefore, in this case, as in the case of the paralytic, we see again that how one contracted a disease did not place them outside Jesus' compassion.

The Parable of the Last Judgment

This parable is recorded in Matt 25:31-46; it is also called The Parable of the Sheep and the Goats. In this parable, Jesus states that at the judgment those who will be 
pronounced righteous (symbolized by the sheep) will be those who have shown kindness to Him by showing kindness to fellow human beings. Similarly, those who will be condemned (represented by the goats) will be those who have declined to show kindness to Christ by not showing kindness to other needy human beings. Thus, as MacDonald (1990) correctly concludes, Jesus' point in the parable of the last judgment is that $\mathrm{He}$ regards whatever is done for anyone of His creation as done to Him, and neglect of any of His followers constitutes neglect of Himself (p. 1299). In other words, in this parable Jesus completely identifies Himself with His creation.

This point is a very significant one for the purpose of our study, considering that some of the people who were shown kindness and with whom Jesus completely identifies Himself were "the sick" (vv. 39, 43). In other words, The Parable of the Last Judgment reminds us that Jesus is concerned by the suffering of His people. For this reason, He identifies Himself with them completely. Therefore, Jesus expects all who follow Him to care for the sick as they would if He was there in person. And which believer would not wish to do the best for Jesus were He to appear as a sufferer?

The last passage is The Parable of the Good Samaritan, to which we turn next.

The Parable of the Good Samaritan

Only Luke, a physician, narrates The Parable of the Good Samaritan (Luke 10:3037). The context shows that Jesus told the parable in response to a question raised by a teacher of the law who came to ask Him what he needed to do in order to inherit eternal life. Jesus told him to keep the law. However, this young lawyer countered saying he had kept the law from his childhood. It was then that Jesus reminded him of his duty to love his neighbor as himself. It may have been out of a desire to silence Jesus that the lawyer 
asked Jesus: "Who is my neighbor?" (v. 29). It was to answer this second question that Jesus told The Parable of the Good Samaritan (vv. 30-37).

In the parable, Jesus depicted a man who was traveling from Jerusalem to Jericho when he was attacked by thieves who wounded him, stripped him of his raiment, and departed, leaving him half dead (v. 30). It so happened that a priest passed by, but he ignored him, passing on the other side. So did a Levite who passed that way also. After these two had passed by, hurrying off to the Temple to worship the Lord (vv. 31-32), a Samaritan also passed that way. According to the parable, though the Samaritans were not on good terms with the Jews (and without consider for his own safety) this despised Samaritan not only aided the unfortunate victim, but also committed himself to pay whatever bills would accumulate in the course of his treatment. Thus, the Samaritan's attitude stood in stark contrast to that of fellow Jews, a priest and a Levite.

When Jesus asked the young Pharisee which one of the three people who met that unfortunate man behaved like a neighbor, the teacher of the law without any hesitation replied "The one who showed him mercy." To that Jesus responded: "Go and do likewise" (v. 37).

The point of the story of the Good Samaritan, according to MacDonald (2005) is that "if a Samaritan could prove himself a true neighbor to a Jew by showing mercy to him, then all men are neighbors" (p. 1411). And, according to Ellen White (1940), the answer to the question Who is my neighbor? is "everyone:"

Our neighbor does not mean merely one of the church or faith to which we belong. It has no reference to race, color, or class distinction. Our neighbor is every person who needs our help. Our neighbor is every soul who is wounded and bruised by the adversary. Our neighbor is everyone who is the property of God. (p. 503) 
Therefore, this parable clearly shows that Christ's compassion goes beyond any ties, whether religious or filial, to encompass every human being. Hence, The Parable of the Good Samaritan teaches that our neighbor is everyone in need of help, irrespective of religion, race, color, or class. In other words, neighborliness is determined more by need than location or relationship. While all are neighbors, the one in need stands in more need of a neighbor to show them kindness than one who is in no immediate need. Could it be for the same reason that the saying goes "A brother in need is a brother indeed?"

Of Jesus, the great example for Christians, Ellen White (1940) tells us:

From the homes, the shops, the market places, the inhabitants of the city pressed toward the humble dwelling that sheltered Jesus. The sick were brought upon couches, they came leaning upon staffs, or, supported by friends, they tottered feebly into the savior's presence.... All day He toiled, teaching, healing the sick, giving sight to the blind, feeding the multitude; and at the evening or in the early morning, He went away to the sanctuary of the mountains for communion with His Father. (pp. 259-260)

Contrast the above description of Jesus with another Ellen White (1940) depiction of His followers and the warning embedded in it-that failure to show kindness to others amounts to a denial of Christianity however exalted one's profession may be:

Selfishness and cold formality have well-nigh extinguished the fire of love, and dispelled the graces that should make fragrant the character. Many who profess His name have lost sight of the fact that Christians are to represent Christ. Unless there is practical self-sacrifice for the good of others, in the family circle, in the neighborhood, in the church, and wherever we may be, then whatever our profession, we are not Christians. (p. 504)

The above review of Jesus' words and actions, therefore, has established that compassion was the main springboard of Jesus' miracles of healing. This was the case because he was always touched by human suffering. Further, the survey has shown that Jesus' compassion was not affected by how a person contracted their illness in the first place. Those who brought disease upon themselves and those who never contributed in 
any way to their suffering were graciously healed by Jesus. To Jesus what mattered most was whether a person was in need of relief. This survey has also shown that Jesus' compassion encompassed both Jews and non Jews. The instances of healing discussed above, though few due to the scope of this study, illustrate our loving Savior's attitude towards sickness and suffering, and suggest how Christians should relate to those who are afflicted. The parables of the Last Judgment and the Good Samaritan give no room for lack of involvement whenever there are fellow human beings suffering around us. To do so would not only be a betrayal of humanity, but a denial of Christ who suffers in the stead of all His created children.

Hence, we can surmise from the above that compassion would make today's believers different from those who can afford to idly watch as people around them suffer just as it made Jesus different in His day. Compassion made Jesus different from the Jewish leaders of His time in the sense that, as Ellen White (1940) points out, while the latter "regarded affliction as evidence of divine displeasure, and thus held themselves aloof from the sick and the needy" (p. 267). Jesus took pleasure in healing them and watching them go home rejoicing (p. 259). Thus, if Christians today had compassion like their Master, they would gladly minister to the suffering and needy in society, as He did. In addition to showing compassion in each of these episodes, Jesus also demonstrates leadership. He took the initiative by actively providing a practical solution to change the situation of the sufferer. And because of this active leadership the multitudes followed Him (Matt 4:23-25).

In short, society needs the expression of compassion and clear leadership by all those who profess to believe in God, just like Jesus demonstrated in His ministry. At the 
same time, Christianity without compassion is not Christian at all. In other words, Christianity itself cannot exist apart from compassion, anymore than society can last without compassion.

\section{Summary}

The chapter has examined Jesus' healing of the leper, the paralytic dropped through the roof, and the invalid by the pool in Bethesda. It also reviewed two parables Jesus narrated, namely, the parables of the Last Judgment and the Good Samaritan.

Doing so has revealed our Savior's attitude towards the sick and human suffering: He was always moved by compassion to help relieve those who were suffering. How Jesus related to human suffering informs us of how Jesus would relate to human suffering today in the face of the deadly HIV/AIDS epidemic. Adulterous or homosexual activity would not inhibit His compassion.

Jesus' teaching and example show that it is not necessary to separate preaching the Word of God and doing works of mercy. Doing so is not only contrary to Christ's example during His earthly ministry, but also contrary to His teaching. Thus, combining preaching with works of charity is not an option, but a divine imperative. This chapter, therefore, has established that it is not only proper for Christians to be involved in alleviating and mitigating suffering, such as that caused by HIV/AIDS, but a divine duty. To do otherwise is to deny Christ in the person of the suffering ones; it is refusing to be Good Samaritans.

Therefore, if the Church would follow the ministry and example of Jesus, as the Body of Christ on earth, she would help resolve the "shortage of compassion and human leadership" (UNAIDS, 2006a, p. 3) that is lacking, and thus help accelerate the fight 
against the HIV/AIDS pandemic. Further, by being so engaged, the Church would identify with its master, Jesus, who during His earthly ministry was always "moved by compassion" whenever He saw those who were afflicted. In other words, if Christians are following the example of Jesus, there is no way they could idly watch the suffering that is all around without being propelled by compassion to do something to help those who are affected. And, as Paul Shongwe (1998) warns, the Church will forfeit her credibility if she ignores the plight of the needy and condones social injustices (p. 202). Therefore, the Church cannot afford to "pass by on the other side" like the priest and Levite in Jesus' parable of the Good Samaritan (Luke 10:35). To do so, in the light of Jesus' teaching and example in Scripture, would be a denial of the Master Teacher and a betrayal of humanity at its highest point of need.

Hence, this chapter lays the theological foundation for Christian involvement in the contemporary fight against HIV/AIDS propelled by the same compassion Jesus manifested in His life and ministry. The previous chapter highlighted the need to investigate the reasons for the aloofness of the SDA Church in the contemporary fight against HIV/AIDS. The present has shown that such aloofness is actually contrary to Jesus' teaching and example. But, it is still necessary to establish the reasons why believers would shy away from engaging in the fight against the AIDS pandemic contrary to scriptural teaching. Chapter 3, therefore, examines the literature on HIV and AIDS with a view to understand the challenges facing the fight against HIV/AIDS. 


\section{CHAPTER 3}

\section{HIV/AIDS PANDEMIC: LITERATURE SURVEY}

\section{Introduction}

Chapter 2 of this study put forward the case for the introduction of what was there referred to as the compassionate factor in the fight against HIV/AIDS-involvement of more and more Christians in the fight, who volunteer their services motivated by the love of Christ. Compassion was shown to be the missing ingredient needed to spur the fight against HIV/AIDS to sustainable success. This chapter builds on that. It surveys the available literature on the HIV/AIDS pandemic in order to establish the place for compassionate Christian involvement in the anti-AIDS fight. The strategies in use to fight the epidemic are closely examined, with special attention given to the challenges encountered in the fight.

As Zambia AIDSLAW Research \& Advocacy Network, ZARAN (2006) has rightly pointed out, the issues surrounding HIV/AIDS are "vast and complicated" (p. 10). Admittedly, a pandemic as widespread and devastating as HIV/AIDS has many aspects. In other words, the scope of the disease alone calls for extensive coverage of the many aspects of the epidemic. However, due to the limited scope of this study, this literature review is divided into the following categories: (a) the theories of origin of HIV/AIDS, (b) the impact of HIV/AIDS, (d) strategies to combat HIV/AIDS, (e) challenges to HIV and AIDS combatancy, (f) the fight against HIV and AIDS-success or failure, (g) 
towards a more sustainable and successful fight against the HIV/AIDS pandemic, and (h) a summary of the findings and the implications of the literature review.

\section{The Development and Origin of HIV and AIDS}

In the introductory chapter, HIV and AIDS, as well as other terminology related to the AIDS pandemic were defined and explained. Here we will just briefly explain the course of HIV and AIDS, as well as look at theories of its origin.

\section{Development of HIV}

The mysterious manner by which the virus ingenuously enters the cells of the body's defense mechanism is what has made HIV/AIDS the deadly disease it is today. The available literature reveals that in order for the virus to establish infection in a person, the virus must enter cells such as lymphocytes, the defense cells of the body. In this way, the genetic material of the virus is incorporated into the DNA of an infected cell. The virus then reproduces itself inside the cell, eventually destroying the cell and releasing new virus particles. The new virus particles then infect other lymphocytes and can destroy them as well. The virus attaches itself to lymphocytes that have a receptor protein called CD4, also called CD4-positive (CD4+) cells or helper T lymphocytes. CD4 (T4) is a protein receptor embedded in the cell surface of T lymphocytes, monocytes/macrophages, Langerhans cells, astrocytes, keratinocytes, and glial cells. HIV invades cells by first attaching to the CD4 receptor molecules. T4 Cell refers to a type of T-lymphocyte. The T4 cell enhances the immune response to an infection through a complex series of interactions with other types of lymphocytes (B cells, T8 cells), macrophages, antibody-producing cells, and infectious organisms. These helper T cells serve to activate and coordinate other cells of the immune system which help to destroy 
cancerous cells and invading organisms. In this way, HIV infection weakens the body's immune system because it destroys helper T lymphocytes. AIDS begins with a low CD4 +lymphocyte count (less than 200 cells per micro liter of blood) or the development of opportunistic infections. Both the HIV infection itself and the opportunistic infections and cancers produce the symptoms of AIDS (Berkow, Beers, Bogin, \& Fletcher, 1997, pp. $927,929-930)$.

\section{The Origins of HIV/AIDS}

The literature reviewed for this study reveals that HIV/AIDS first came to light in the early 1980 s when epidemiologists recognized a sudden increase in Kaposi sarcoma, a rare type of cancer, and pneumocystis pneumonia, especially among homosexual men in the US (Berkow et al., 1997, p. 926). Other places where the disease was first sighted include the Democratic Republic of the Congo (DRC) and Uganda, on the shores of Lake Victoria. By 1985, however, there were reports of the disease in every region of the world, so much that a group of scientists and health professionals from around the world gathered to recommend a strategy for AIDS prevention and control for endorsement by the UN. The UN reports that since the 1980s the AIDS pandemic has spread relentlessly from the widely scattered "hot spots" to virtually every country in the world. (UNAIDS, 2005 , p. 2) However, there is no agreement as yet as to the origin of HIV/AIDS. The theories of origin vary from comets, curses, to conspiracy, accidental emergence, to transmission from animals (Willis, 2002, p. 64). Willis briefly reviews these theories, but like others, does not suggest which one would be the correct one. 


\section{The Impact of HIV/AIDS}

The United Nations and WHO now recognize AIDS as the world's most prevalent fatal disease and the largest cause of death in Africa (Willis, 2002, p. 3). According to the UN, the number of PLWA continues to grow-as does the number of deaths due to HIV/AIDS. As of Dec 2006, there were approximately 39.5 million PLWAs worldwide. In that year alone, 4.3 million new cases of HIV/AIDS were reported and 2.9 million PLWA died. During the two years from 2004 to 2006, the number of people living with HIV/AIDS increased by a staggering 2.6 million. With 6,000 people infected daily, the prospect that one may be infected accidentally, as the accidental theory proposes, is truly frightening (Willis, 2002, p. 65). But the sad reality is that $2 / 3$ of all the people living with the disease live in sub-Sub-Saharan Africa (UNAIDS, 2006a., pp. 1-2).

Until there is a Cure, a nonprofit international organization dedicated to eradicating HIV/AIDS by raising awareness and funds to combat this pandemic gives us an idea about the impact HIV has had on youth and children. Referring to HIV/AIDS as a "disease of young people" with $45 \%$ of the new infections each year occurring among people ages 15 to 24 , Until There is a Cure informs us that annually, there are 70,000 new infections of children under age 15. Many of these children are or will become orphans. Without treatment, approximately half of the children with perinatal infection will die by the age of two.

It is now an established fact that while HIV/AIDS has affected the entire world, Africa, in particular Sub-Sahara Africa, is the worst affected. According to Malungo (2005), of the estimated 40 million PLWA worldwide, some $95 \%$ live in the developing world; with two thirds in Sub-Saharan Africa-a place home to only $10 \%$ of the world's population of 6 billion. The situation is so bad that the lifetime chances of dying of AIDS 
in Sub-Sahara Africa is around 30\% in some countries and between $60-70 \%$ for the region (p. 41). Overall, this region is home to 24.7 million PLWA-an increase of 1.1 million cases in only 2 years.

These statistics are similar to those reported by UNAIDS in 2004. According to UNAIDS, by 2004, between 23.4 and 28.4 million people were infected by HIV/AIDS in Sub-Saharan Africa (representing around $65 \%$ of the worldwide total), between 2.1 and 2.6 million died from the virus and between 2.7 and 3.8 million became newly infected (UNAIDS, 2004a p. 2). It is now estimated that around the world, 16,000 new cases of HIV occur daily, $10 \%$ of which are children, $50 \%$ are young between $15-24$ years old, and $40 \%$ are women (UNAIDS, 2003 , p. 1).

Unfortunately, the overall picture is not improving elsewhere. While Sub-Sahara continues to be the world leader in HIV/AIDS cases, it is noteworthy that during the same period the number of PLHIV increased in every region of the world. The most striking increases occurred in East Asia and Central Asia, where the number increased by $21 \%$ (UNAIDS, 2003, p. 1). The UNAIDS office reports that the AIDS pandemic has matured in Africa but the Eastern Europe and South-East Asian pandemics have begun to rival that of Sub-Saharan Africa in scope (UNAIDS, 2006b, p. 3). The situation in several Asian countries like Cambodia, India, Myanmar and Thailand is also becoming increasingly worrisome.

The UNAIDS 2007 Report reduces the number of PLHIV and PLWA to no more than 36 million from the over 38 million reported in the previous year's report. Is that an indication that the number of people dying from the disease may be reducing from henceforth? The literature reviewed suggests that unfortunately, such a conclusion would 
be inaccurate. The given reason for the reduction is due to improvement in the methodology used to estimate HIV epidemics applied to an expanded range of country data, particularly persons living with HIV worldwide, and not due to an actual reduction in the number of people infected or living with AIDS (UNAIDS, 2007, p. 1).

In view of the foregoing, it is not surprising that HIV/AIDS is regarded as the most devastating pandemic ever seen. Not only is it a major health problem, but also a development issue seriously threatening the economic and social fabric of many developing countries. To that effect, former United Nations Secretary General Kofi Annan, in his preface statement to the UN 2006 Report on HIV/AIDS (a report specifically written to mark 25 years of AIDS activism), considers the disease "the greatest threat to global progress in the 21st century":

This year marks a quarter of a century since the first cases of AIDS were reported. AIDS has fundamentally changed our world-killing more than 25 million men and women, orphaning millions of children, exacerbating poverty and hunger, and, in some countries, even reversing human development altogether. Nearly 40 million people are living with AIDS today-half of them women. What was first reported as a few cases of a mystery illness is now a pandemic that poses among the greatest threats to global progress in the $21^{\text {st }}$ century. (UNAIDS, 2005, (Annan, 2006, n.p.)

According to D. de Walgue (2006a), AIDS is "the greatest challenge facing Africa" (p. 2). However, the point is that whether in Africa or beyond, HIV/AIDS has caused the death of many millions, especially those in the productive category, thereby increasing the number of orphans, and exacerbating poverty and hunger.

But what has been the impact of the pandemic on the Zambian population? Like elsewhere in Sub-Sahara Africa, the status of the HIV and AIDS epidemic in Zambia is devastating. In 2000 when the population was about 10.3 million and the annual population growth rate at $2.9 \%(\mathrm{GRZ}, 2003, \mathrm{p} .55)$, Zambia was rated as one of the Sub 
Saharan African countries worst affected by the HIV and AIDS pandemic. Estimates then put the prevalence rate at about $16 \%$ among the 15-49 years old age group and about 1 million Zambians infected with HIV, of which over 200,000 are in desperate need of antiretroviral therapy. Of those infected by HIV, 7.7\% of young people aged 15-24 years old and $40 \%$ of infants born to HIV infected parents are infected. More than $50 \%$ of the population is less than 20 years of age and constitutes the most vulnerable group to new HIV infection (NAC National HIV AIDS Strategic Framework, p. 7).

Similarly, HIV/AIDS has reduced the population of Zambia by 2 million in the last 10 years (GRZ, 2003, p. 55). It is estimated that about 1 million Zambians are infected with HIV, of which over 200,000 are in need of antiretroviral therapy (National HIV and AIDS Strategic Framework, p. 7). However, as World Bank (2005b), rightly observes, the numbers reported are not mere statistics; they represent, "fathers and mothers, brothers and sisters, doctors and nurses, primary school teachers, electrical engineers, community leaders, finance managers, entrepreneurs, students, researchers, and farmers trying to lift their families out of poverty whose 'spouses and children are now condemned to new hardship" " (p. 9).

The situation therefore is desperate and urgent. Therefore, "Now is the time for Africa—and the world—to fight back" (World Bank, 2005b, p. 10). Especially for Africa where the pandemic has had its worst toll, the time has come to get rid of the fatalistic attitude and acceptance of the disease and even death from it; something that is so surprising, especially to foreigners (Health Transition Centre, 1999, p. 1). Concerted effort must be put to slow down or stop the massive infection rates that have characterized the pandemic on the continent. Yes, now is the time to give fresh hope and 
new resources. Indeed, "Now is the time to act-and to act decisively" (World Bank, 2005b, p. 9).

Considering that a lot has been done until now and yet the pandemic continues to grow, it makes sense to learn to act in ways we may not have considered useful until now. For, indeed, if we must raise the fight against the pandemic to higher heights than we have attained, we must act differently, for as Paul Ratsara (2009) put it, to continue doing what we have always done, but expecting to get different results is equal to madness. What is it that has been missing from our activities in the past? Let's look at the different strategies that have been employed so far.

\section{Strategies to Combat HIV and AIDS}

The WHO and World Bank have been very instrumental in developing and funding most of the strategies that have been used in the fight against HIV/AIDS. Since the early 1980s, the WHO whose core functions are defining knowledge and knowledge gaps relevant to health, helping to establish health policy, issuing technical guidance and recommendations, and monitoring health trends, and has been active in translating the evolving science of HIV/AIDS into practical advice for countries as they respond to this severe, heterogeneous, and complex epidemic. WHO coordinated the early global response to HIV/AIDS through its Special (later Global) Program on AIDS. Working closely with ministries of health in low-and middle-income countries, WHO provided evidence-based programs to combat the new disease. Following the establishment of the Joint United Nations Program on HIV/AIDS (UNAIDS) in 1996, and the agreed division of labor between its cosponsoring organizations, WHO remained the lead agency for the health-sector response to HIV/AIDS (WHO, 2009, p. viii). 
In 2003, three key initiatives in the global AIDS response were launched: (a) the Global Fund to Fight AIDS, Tuberculosis and Malaria, (b) the United States President's Emergency Plan for AIDS Relief, and (c) the WHO/UNAIDS 3 by 5 initiative. The resulting programmatic scale-up highlighted a need for sound, evidence-based, impartial guidance for public health action.

Building on the achievements of the 3 by 5 and other initiatives, leaders of G8 countries (Canada, France, Germany, Italy, Japan, Russian Federation, United Kingdom, and United States) meeting in 2005 in Gleneagles, Scotland, committed to working with international organizations to develop and implement a package of interventions, with a view to achieving universal access to HIV prevention, treatment, care, and support-a goal later endorsed by Member States at the United Nations General Assembly. However, the nature of this essential package had yet to be defined.

In the aftermath of the 3 by 5 Initiative, WHO has been acutely aware of the increasing importance of the health sector in the quest for universal access, and in tracking the epidemic and monitoring the response. The original call by G8 leaders for a package of interventions - coupled with the need for ongoing and updated user-friendly technical guidance-led WHO to develop an umbrella report that brings together in one place key WHO guidance and references for the health sector response to HIV/AIDS. This report was released in May 2009 under the title "Priority Interventions: HIV/AIDS Prevention, Treatment and Care in the Health Sector." This document, an initial version of which was launched in August 2008, at the global AIDS conference in Mexico City, defines the essential interventions the health sector should deliver, and provides key references and links to web-based resources. The report offers WHO's best attempt to 
assemble and package normative advice for the health sector on the essential response to HIV/AIDS. True to its name, the report discusses the most commonly used interventions to fight the pandemic (WHO, 2009, p. viii).

Among these is the multi-sectoral approach. This strategy is founded on the need for broader-based consultation (GRZ, 2008, p. 16). The Zambian Government, through an Act of Parliament, established the NAC to spearhead the fight against HIV/AIDS in the country.

The council draws its membership from a wide range of stakeholders, including the following: Permanent Secretaries in the Ministries of Community Development and Social Welfare; Sport, Youth and Child Development; and Education and Health. Other members of NAC include: The Attorney-General's Office; Network of People Living with HIV and AIDS (NZP); Zambia National AIDS Network (ZNAN); Forum of Youth Organizations FYO); Traditional Healers Association of Zambia (THAZ); Medical Council of Zambia (MCZ); General Nursing Council of Zambia; and the Media (GRZ, 2008, p. 10).

The mission of the NAC Board and Secretariat is to oversee, drive, and convene a multi-sectoral national response is at the heart of Zambia. Principally, NAC is responsible for supporting the development and coordination of policies, plans, and strategies for the prevention and combating of HIV, AIDS, STI, and TB. In this regard, NAC advises the government on all matters relating to prevention, care, and treatment of HIV, AIDS, STI and $\mathrm{TB}$, including research in areas targeted at mitigating the socio-economic impact of these diseases. The execution of this mandate is led by the NAC Secretariat that coordinates HIV and AIDS activities throughout the country and closely works with 
public, private, and civil society institutions engaged in the fight against the pandemic (GRZ, 2008, p. 11).

To promote proper coordination and efficiency in the fight against the pandemic, in April 2004, the UNAIDS co-sponsors, the Global Fund, the World Bank, and key bilaterals, (including the U.K. and the U.S.), agreed to support the Three Ones at country level, in order to improve the efficiency and effectiveness of HIV/AIDS funding. The Government of the Republic of Zambia (GRZ) accepted the Three Ones protocol and became a signatory to it. The Three Ones principles provides a useful framework for development of the Zambian AIDS response by ensuring that there is (a) one agreed HIV and AIDS Strategic Framework that provides the basis for coordinating the work of all partners; (b) one National AIDS Coordinating Authority, with a broad-based multisectoral mandate; and (c) one agreed country-level Monitoring and Evaluation System. Based on these, the Zambian Government developed a National HIV and AIDS Strategic Framework (NASF) for the period 2006-2010 — the successor of the Strategic Intervention Plan of 2002-2005. The Zambia NASF is basically a multi-sectoral plan with six themes: namely, intensifying prevention of HIV and AIDS; expanding treatment, care and support for people living with HIV and AIDS; mitigating the socio-economic impact of HIV and AIDS; strengthening the decentralized response and mainstreaming HIV and AIDS; improving the monitoring of the multi-sectoral response; and integrating advocacy and coordination of the multi-sectoral response (GRZ, 2008, p. 20).

Thus, the Zambia NASF combines both mainstreaming and the multi-sectoral strategies and harnesses them. Mainstreaming action is an essential approach for 
expanding, scaling up, and implementing multi-sectoral responses to HIV and AIDS UNAIDS, ILO, UNDP, (Joseph \& Kouassi, 2005, p. 16)

The other strategies mentioned in the literature belong to the prevention category, because, contrary to popular opinion, behavior change is still a critical intervention in the fight against the pandemic. Speaking to journalists in Lusaka, the capital city of Zambia, Donald Booth, the new U.S. Ambassador to Zambia, Booth, underscored this point recently. Thanking the Zambian Government for having made a lot of progress in reducing stigma on HIV and AIDS, Booth said because until now, no cure for AIDS has been found, "prevention is very important" (The Post, 2009, p. 8).

Ambassador Booth was right. The successes of the modern strategies being used today should never lead us to undermine the place of the age-tested strategy of prevention. This is especially the case with AIDS because, unlike many other diseases, AIDS is completely preventable (World Bank, 2005b, p. 7). If ever there was a case where the old adage "prevention is better than cure" applies, it is with AIDS!

Recognizing the critical role of prevention to the fight against HIV/AIDS, the Churches Health Association of Zambia (CHAZ), the umbrella body coordinating the activities of FBOs in the country, has developed a document it calls a "Toolkit for the Prevention of HIV and AIDS." The uniqueness of this document lies in the fact that it aims at building the competency of the local community in order to make prevention attainable (Churches Health Association of Zambia, 2006, p. 98). This community involvement, as we saw earlier, is inevitable if strategies are to be both effective and sustainable. There is need for all to be involved, for as UNAIDS (2006a) cogently 
pointed out, "in the 21 st century, we are all living with HIV, and we must all be part of the response" (UNAIDS, 2006, p. 6).

The literature surveyed for this study discusses many different prevention strategies in use today in the fight against HIV/AIDS, too numerous to discuss here given the scope of this paper. The prevention strategies include the use of condoms, male circumcision, Modeling and Reinforcement Change HIV (MARCH), and Appropriate information, education, and communication (IEC) (World Bank, 2005, p. 14)], to name only a few. All these strategies emphasize behavior change. There is also Prevention of HIV transmission to pregnant women, mothers and their children (PMTCT) or simply PMTC (Garbus, 2003, p. 92).

At the time of writing, (end of February 2010), the Minister of Health of the Republic of Zambia, just announced on national television that Government was very disappointed by microbicides tests which had been carried out in a town some $125 \mathrm{~km}$ south of Lusaka, the national capital. The reason for the disappointment is the fact that the tests had proven to be only $30 \%$ effective. On the other hand, male circumcision has been established to be $60 \%$ effective. Even just common sense dictates that circumcision as an HIV/AIDS combatancy strategy should be given a high premium.

The use of ARVs is one of the treatment strategies which has not only elongated the lives of many thousands of people globally, but also brought back hope to many. However, the benefits from these strategies are curtailed by many serious challenges.

\section{Challenges Hampering the HIV and AIDS Fight}

The fact that the fight against HIV/AIDS has not been successful can longer be denied. Otherwise, as one author rightly asked "if we really have learned so much about 
HIV over the last two decades, then why is the epidemic still growing? Why will more people be infected with HIV and die of AIDS in 2005 than in any previous year? In short, why aren't we applying what we know?" (World Bank, 2005b, p. 15)

Similarly, UNAIDS (2006a), in its $10^{\text {th }}$ anniversary special report reflecting on 25 years of AIDS activism, complained of some "enormous and often frightening divides" between the number of people in need of help and the number being helped and between what could be done to stop AIDS, and what was actually being done (UNAIDS, 2006, p. 3). The report also regretted the fact that there were many new infections of the disease that could have been averted by the implementation of a comprehensive range of evidence-based prevention measures. Thus, even though in 2005 Peter Piot, the Executive Director of the UNAIDS, claimed that the "most concrete proof that AIDS is a problem with a solution" is the decline of AIDS epidemics in more and more countries in every continent (UNAIDS, 2006, foreword), it is evident from the foregoing that the fight against HIV/AIDS is facing serious challenges. To the contrary, the literature surveyed for this study highlights some serious challenges that are negatively affecting the fight against the HIV/AIDS pandemic. A brief discussion of three such challenges follows below.

The first is the failure to address the social context of those affected by HIV/ AIDS. Social psychologist Catherine Campbell (2003), writing about HIV uses two key and highly suggestive questions: (a) why do people in HIV/AIDS ravaged countries continue to engage in unsafe sex, which they know could kill them? and (b) why do programs designed to prevent the progression of the HIV/AIDS pandemic fail to make this point? (pp. 1-2). Moving away from what has been hitherto the central focus of 
HIV/AIDS projects: changing individual sexual behaviors, Campbell's thesis is that, in the final analysis, people's understanding about HIV/AIDS, their belief about themselves, and what they do in their sexual lives is not entirely based on their own choice. Instead, their choice is significantly shaped by a complex interplay of social norms, opportunities, expectations, and constraints. In other words, Campbell argues that the main reason why HIV and AIDS interventions have failed is due to failure on the part of those involved in the fight against the pandemic to take into account the socio-economic factors at play in the lives of the people they wish to help.

Campbell is not the only one who sees the role socio-economic issues play in determining people's sexual behaviors. D. de Walque (2006) using demographic and health surveys from five Sub-Saharan countries came to three conclusions all of which point to the significant contribution social-economic factors play in precipitating the pandemic. The first was that married women who engage in extra-marital sex are less likely to use condoms than single women. Second, that having been in successive marriages is a significant risk factor. And third, that while education predicts protective behaviors like condom use (use of counseling and testing, discussion among spouses, and knowledge), it, however, and unfortunately, also predicts higher levels of infidelity and a lower level of abstinence (pp. 10, 12).

Similarly, F. Williams (2009) argue that Socioeconomic Status (SES), usually measured by a person's income, education, or occupation, influences health in virtually every society, and is one of the most powerful predictors of health, even more powerful than genetics, exposure to carcinogens, and even smoking. Thus, SES is a key determinant of health. 
The study revealed that Americans who have not graduated from high school have a death rate two to three times higher than those who have graduated from college, low SES adults have levels of illness in their 30s and 40s that are not seen in the highest SES group until after the ages of 65-75.

Based on the findings mentioned above, Williams (2009), among other things, recommend that (a) effective health care delivery must take the socio-economic context of the patient's life seriously, (b) the health problems of vulnerable groups must be understood within the larger context of their lives, (c) the delivery of health services must address the many challenges that they face and take the characteristics and needs of vulnerable populations into account, and (d) this will involve consideration of the strengths of the client, the support and barriers in the client's environment, and the nonmedical resources that may be mobilized to assist the client.

The GRZ (2008) also, after noting that the major mode of HIV transmission in Zambia is heterosexual, through which $78 \%$ of the country's HIV infection is transmitted, significantly adds that this mode of transmission is exacerbated by three factors, namely, high-risk sexual practices, poor socio-economic status of women, and high prevalence of STIs (p. 4). All three are socio-economic.

Renown Zambian HIV/AIDS researcher, Jacob Malungo, also recognizes the role that socio-economic factors play in advancing the HIV/AIDS pandemic. Using a research method he calls the congregational technique, which involves organizing large groups of people, or congregations, of up to 100 people for discussions, Malungo studied the premarital sexual behaviors of people living in the southern part of the country of Zambia. He came to the conclusion that premarital sexual relations were very rampant in 
the area and a high risk factor in the spread of the pandemic. Malungo made two recommendations that could help address the problem, namely, (a) that girls be economically empowerment, and (b) that various organizations and traditional leaders be involved in programs designed to fight HIV and AIDS (Malungo, 2005, p. 47). Undoubtedly, the implication of the first recommendation is that girls find themselves under pressure to give in to premarital sexual demands due to their lower socio-economic status. And the implication of the second is that because of its social nature, many stakeholders need to be involved in fighting HIV. The need for the formation of social networks and partnerships in the fight against AIDS is doubtless thus implied, but we will come back to that later in this chapter.

However, while the role socio-economic factors play in exacerbating the HIV and AIDS pandemic is undeniable, as David Harrison (2005) correctly cautions, we must avoid the "reductive trap of equating HIV prevention with poverty alleviation, where HIV is viewed as yet another social blight that will dissipate once poverty does" (p. 257).

But, the failure to see and understand the role socio-economic factors play in exacerbating the HIV and AIDS pandemic is related to another challenge-the failure to identify new challenges and to devise appropriate responses to them. The World Bank (2005b), projects that as the epidemic and the worldwide response to it continue to evolve, new challenges and new obstacles will continue to emerge, most of them caused by "tremendous diversity across and within regions and countries" (p. 14). Thus, identifying new challenges and devising appropriate responses to them must be part of any effort to advance the fight against the pandemic. 
According to the World Bank (2005b) the challenges include:

The need for good surveillance, to understand the specific transmission dynamics in each context or country in order to design effective interventions; the need to ensure that interventions reach target groups in concentrated or low-level epidemics; the need for a comprehensive approach in generalized epidemics; the overarching need for strong political commitment and broad social mobilization to end stigma, silence and denial no matter what the epidemic stage, and to change the cultural norms, beliefs, roles, and practices in which sexual behavior is deeply rooted. (p. 14)

Other challenges include information bottlenecks, financial bottlenecks, stigma, lack of capacity by the available medical institutions to cater for those affected by the disease, experimentation of what works and what does not, lack of clarity about best practice, and lack of unified response from various stakeholders (R. Lewin, 2005, p. 152). But, the challenges in countries experiencing highly generalized epidemics are more varied. These include the challenges "to build local capacity to manage a long-term, chronic disease; to ensure long-term maintenance of safer behaviors; to provide longterm support to survivors; and to plan for cohorts of young people who may begin risky behaviors in the future" (World Bank, 2005b, p. 14). Such challenges require the use of both multi-message and multi-medium approaches which have the capacity to trigger the mass social movements required to tip the balance towards successful and sustainable mitigation of the epidemic (Harrison, 2005, p. 258).

Capacity building has been defined as

A process to support, enhance and strengthen organizational and individual ability to realize a core purpose. It is not once-off training which is known to have limited effect and impact. Capacity building goes beyond training and must involve support and mentoring for maximum effect. The organizational component is about strengthening institutional capacities and the individual component is about strengthening individual skills and abilities. Any good capacity-building effort will use active learning as the most appropriate strategy for both organizations and individuals. (E. Atmore, 2005, p. 243) 
Capacity-building in the fight against HIV and AIDS stresses the significance of developing long-term maintenance of safer behaviors and safe-guarding more young people from engaging in risky behaviors. Lanaine Abrahams (2005), of British American Tobacco South Africa-a company which through its Signature Trust is providing hope to South African youth underscored this point when she noted that "successful HIV/Aids education is about changing behavior." This is because, as Abrahams points out, in most societies, "effecting behavioral shifts requires altering cultural belief systems and entrenched prejudices" (p. 192). But then, that can best be done while people are still in their formative years-in their youth. And Abrahams asserts that research has established that "low-risk behavioral patterns are established with greater ease early in life, emphasizing the importance of school-based interventions" (p. 192).

While educating young people to avoid engaging in risky behaviors can be an elusive goal, David Harrison (2005) argues that it is, in fact, this focus on youth that holds promise for success in this global fight. According to Harrison, because the youth are one of the groups highest at risk of HIV, empowering them to deal with the HIV/AIDS pandemic has the potential to "starve" the pandemic and reverse the trend.

The stewed risk profile in a young population leading to infection early in life constantly reinforces the wave front of HIV. Yet, these very same factors hold the key to significantly reducing HIV rates: given the skewed distribution of risk, a relatively modest shift in sexual behavior would move a disproportionate number of young people out of the high-risk pool; sharp declines in incidence would starve the epidemic of its oxygen; and the effect of the youth bubble growing relatively HIV-free would amplify 
the change. These factors explain why a focus on teenagers is likely to yield highest returns (p. 256).

Admittedly, educating young people to avoid engaging in risky behaviors, can be an elusive target. For one thing, as Angela Ho (2005), Community Affairs Manager for Coca Cola (SA) points out, "Changing behavior is difficult." This is partly because to date there are still many questions about what kind of interventions work best to promote abstinence, delay and change behavior among youth (p. 154). But, what could help in our efforts to achieve such a feat, as Sunette Pienaar (2005) has rightly pointed out, is to listen to the wisdom of the African proverb that says "It takes a community to raise a child" (p. 157). The point is that the task of educating the youth as a primary market in the bid to stop the epidemic can only be achieved if organizations involved in the fight do so in partnerships. Hence, the need for "sustained, strong political commitment, effective multi-sectoral efforts and broad community engagement" all necessary for normative and behavioral changes that prevent HIV infection (World Bank, 2005b, p. 21). Put otherwise, the fight against HIV calls for strong leadership-just what UNAIDS (UNAIDS, 2006b) was calling for: "these advances ... while vitally important to mounting an effective response, do nothing to mitigate the shortage of leadership and human compassion that frequently hinder progress"(p. 3).

The foregoing, therefore, underscores the role of social economic factors in the place of education (including prevention), the critical role that FBOs play in the fight against the pandemic, as well as the involvement of local communities in and the formation of networks play in precipitating HIV. 


\section{The Role of FBOs in Combating HIV/AIDS and Stigma}

The issue of stigma against HIV and PLWA, ironically, is a perennial issue as far as FBO involvement in the fight against the disease is concerned. While we note with a measure of appreciation that "people who work in social development projects often do so from a base of passion and the desire to assist their brethren, rather from profit motive" (Radebe, 2005, p. 167), it is regrettable, as Jean Garland and Mike Blyth note, that "sadly, stigmatization and discrimination still abound within the church, and seriously slow down, and sometimes reverse progress toward preventing and controlling HIV/AIDS" (2005, p. 277). A classic example of the former is Rosalie Mashale (2005), Founder and Director of Baphumelele (which means "progress"), a safe haven for children, the sick, and the needy in Khayelitsha, Cape Town, South Africa. She was voted Woman of the Year (2005) for her astonishing work in sustaining her centre for almost 20 years. When asked what had inspired her to work with vulnerable groups in her community, she tersely said: "I am doing this work because I was moved by the way people were rejected if they got something that was not 'normal' [i.e., if they got physically challenge]" (p. 166).

The experience of the Anglican Church of Southern Africa (ACSA), based on that denomination's experience as it struggled with the reality of AIDS, is a good example of the existence of stigma in an FBO. Entitled The Anglican Church in Southern Africa Report on stigma, the 221 page study discusses the issue of stigma on HIV/AIDS not just in the ACSA churches, but in other churches as well. Is the Anglican Church the only FBO struggling with stigma? Obviously not! The poignant remark by Garland and Blyth (2005) that "sadly, stigmatization and discrimination still abound within the church" (p. 277) should dispel such a myth. But there is no doubt that the ACSA study on stigma in 
its constituent member churches will contribute immensely to the fight against HIV and AIDS.

However, apart from pointing out that stigma exists in its member churches, the study also puts advances a good case for the involvement of Christians in the fight against HIV/AIDS. While the study reveals that being Christian does not seem to be a protective factor against HIV infection, it nonetheless argues that religion can play a very crucial role in combating HIV/AIDS: "Churches can help people to deepen their own spiritual relationships with God, which can improve their ability to deal with a range of challenges including bereavement, serious illness and death." (ACSA, 2006, pp. i-ii). This view is supported by Kostanse Raen (2000) who suggests that spiritual care is able to give PLWAs strength and diminish fear and grief as believers visit them, read the Word of God and pray with them, sharing the gift of forgiveness, and hope of everlasting life with them (p. 65).

Additionally, churches create a very conducive platform for the education of their members in matters related to HIV/AIDS, as well as create support networks for PLWAs. How valuable such networks can be is illustrated by the experience of one woman in Nigeria, who after she realized she had contracted the deadly disease, exclaimed in anguish "the stigma killed me before the disease!" The woman lost her job, her family, her home, and her will to live after contracting HIV/AIDS from her husband. Fortunately, she regained her will to live from a remarkable support group for similar victims of the disease and has lived to narrate the ordeal (World Bank, 2005b, p. 1).

Also, religious organizations can be a source of a comparatively very inexpensive but highly committed human resource. As Busi Radebe beautifully put it, "the use of 
volunteers ... has strong potential for impact. ... Such programs offer the 'feel good' factor and are increasingly being utilized by companies" (p. 168). The result is that time and again these volunteers express "how much personal satisfaction they get from being involved as volunteers" (p. 168). Thus, devoted Christians motivated by the love of God, would help greatly reduce the cost of mitigating the impact of the HIV/AIDS pandemic. Religious organizations are also sources of funds for the fight against the pandemic.

\section{Strategies for Sustainable Response}

While it is true that the AIDS pandemic has outstripped the worst predictions made about it, it is also true that today, for the first time ever, we have the will, means and knowledge needed to make the fight against the disease successful (Piot, P., 2006, foreword). Undeniably, as Kofi A. Annan has correctly noted, there has been remarkable progress in rallying political leadership, mobilizing financial and technical resources, bringing lifesaving antiretroviral treatment to people the world over, to the extent of even reversing the spread in some of the world's poorest nations (Annan, 2006).

Yet, there is need for far greater commitment of political will, courage, and resources to maintain the momentum gained thus far. Moreover, united action is needed on an altogether new scale. This is because, as Piot cogently noted that "AIDS is an exceptional issue which requires "an exceptional response from us all-now and in the decades to come." Two years earlier, Piot had already similarly aptly remarked, HIV/AIDS is "an exceptional epidemic" that demands "exceptional actions" (as cited in World Bank, 2005b, p. 14).

However, in planning to effectively mitigate the impact of the pandemic five aspects need to be put into perspective. First, because there are so many people infected 
with HIV/AIDS increasing priority should be given to treatment, while efforts to prevent new infections must be sustained and enhanced (World Bank, 2005b, p. 13). The need for prevention is underscored by the fact that in South Africa, the country with the highest prevalence of HIV/AIDS in the world (Lewin, 2005, p. 152), 94\% of youth interviewed in one survey said they knew how to avoid HIV infection, but there was no corresponding change in sexual behavior (Harrison, 2005, p. 258). Second, "even in countries with the highest [HIV/AIDS] prevalence, the majority of the population is not infected; and adults and new generations of young people need to be able to protect themselves from the risk of infection" (World Bank, 2005b, p. 13). Third, there is need to develop "a range of strategies ... to prevent new infections, ensure care and treatment for all those affected, mitigate the sweeping impact, and support sustained programs" (World Bank, 2005b, p. 13). Finally, a large percentage of the population is youthful, and they must be at the centre of all efforts to stay the pandemic:

Young people are increasingly at the center of the HIV/AIDS epidemic. More than half of those newly infected with HIV are aged 15-24, and there are more than 12 million young people now living with HIV/AIDS. But young people also represent the future and biggest hope in fighting the epidemic. Nearly all school age children are free of HIV infection, even in the worst affected countries, and if they remain uninfected as they grow up, they could change the face of the epidemic within a generation. Promoting positive and safe behaviors must start before young people become sexually active or begin to use drugs. Many adolescents are sexually active and engage in unprotected sex, and adolescence is also the time when drug use often begins. This is a critical age to provide appropriate information, education and communication (IEC) interventions. Yet, many young people do not have the knowledge or means to protect themselves from HIV/AIDS. (p. 14)

It is shocking, for example, that in some countries with generalized epidemics such as Cameroon, Central African Republic, and Lesotho over $80 \%$ of young women have insufficient knowledge of HIV/AIDS. These need to be educated. Thus, in order to reduce the rate of infections, more information needs to be made available to young 
people using more youth-friendly and gender-specific methods. Also, youth need to be helped to know how they can access health services, VCT.

\section{Use of Condoms}

The issue of youth accessing condoms as and whenever they need them as an STI/HIV preventive strategy is a very hot issue, and is relevant to this discussion. While the prevailing norm today is make condoms available to whosoever needs them, including youths, Abrahams (2005) significantly notes that "successful HIV/AIDS education is about changing behavior" (p. 192). But, that is not the same thing as helping youth to have the so-called "safer sex." Clearly then, the problem with the condom approach to prevention, based on the so-called "A.B.C. of abstinence," is that it removes young people's focus on behavior change at the very time they stand the greatest chance of experiencing such change. And, Abrahams asserts that research shows that "low-risk behavioral patterns are established with greater ease early in life" (p. 192).

In this light then, the contemporary condom social marketing strategies that are being promoted only serve to draw attention from the most effective and sustainable method during young people's youth (the best time). Therefore, whatever the short term benefits of condom social marketing, they are a disservice to the youth, and to the human race considering that youth are society's tomorrow. Therefore, the issue of the use of condoms needs to be separated from human rights, as doing so confuses the real issues at stake. Clearly, the issue is not making it easier for youth to have sex accessibility to condoms because they have the right to have sex.

And while providing HIV/AIDS prevention in schools is critical, programs must also reach youth living in the streets, as well as commercial sex workers, and those 
injecting drugs. And young people themselves need to be involved in these initiatives because including young people in the design and implementation of programs is an effective way to reach and relate to their peers (World Bank, 2005b, p. 13).

It must be obvious from the above literature review that there needs to be a change in the way we have fought the HIV/AIDS pandemic. For the fight against HIV/AIDS to rise to the levels it is capable of reaching, there must be a change in the way the fight is being done, a change not so much in the strategies in use or the amount of resources available-as important as these may be.

In short, the way forward for the fight against HIV/AIDS to be more successful and sustainable is for more and more people to be engaged in fighting the pandemic-in short for all to be involved. And, as UNAIDS (2006a) poignantly points out, the reason why all must be involved is that "in the 21 st century, we are all living with HIV, and we must all be part of the response" (p. 6). One of the most cost-effective but efficient ways of doing so is for FBOs to be involved in the fight and for them to portray the example of Jesus as a means of awakening compassion in the hearts of their members. Confronted with the reality of suffering, on the one hand, and the winning example of Jesus, on the other, many Christians will come to understand what the Bible teaches about suffering and that the Lord Jesus loves the sick, and that in going out to minister to them, they are ministering in Jesus' place.

\section{Summary}

The fight against HIV/AIDS is now nearly 30 years old, but it is clearly far from being over. Many challenges have led to that. Among the challenges hampering the fight against HIV/AIDS are failure to take people's social contexts into account, the failure to 
identify new challenges and to devise appropriate responses to them, limited personnel and funding, information bottlenecks, implementation gaps, stigma, ignorance, resistance to behavioral change or prevention, and lack of compassion on the part of those involved in the fight, to name only a few.

The literature review points a critical need for the involvement of more stakeholders in fighting the pandemic. Doing so would not only increase the number of educators and care givers; it would lighten the burden and make it easier for them, as well as increase knowledge and reduce stigma. 


\section{CHAPTER 4}

\section{THE INVOLVEMENT OF THE SEVENTH-DAY ADVENTIST CHURCH IN THE FIGHT AGAINST HIV/AIDS IN ZAMBIA}

\section{Introduction}

Chapter 2 of this study identified compassion as the springboard of all Jesus Christ's acts of benevolence. The suggestion was made there that compassion could be the element needed today to spur the fight against HIV/AIDS to sustainable success. Building on that, Chapter 3 surveyed the available literature on the pandemic to establish the relationship between compassion and success in the fight against HIV/AIDS.

The literature survey, among other findings, established that given the complexity, the ever evolving nature, and the spread and cost of fighting the disease, the HIV/AIDS pandemic requires concerted, united, collaborative, and synergistic action. In other words, the literature on the pandemic suggests that for the fight against HIV/AIDS to be more successful and sustainable, many more people need to be engaged in the fight against the pandemic than are currently involved. In short, success in fighting HIV/AIDS calls for collaboration, which naturally calls for the formation of strategic partnerships.

The involvement of many more people in the fight against HIV/AIDS would make it easier, for example, to deal with such issues as stigma, ignorance, information bottlenecks, and would help in dealing with the complex interplay of social norms, 
opportunities, expectations, and constraints on people's choices because they would be handled in their natural context.

But, the involvement of more people in the fight against HIV/AIDS calls for increased funding, when already those engaged in the fight are complaining about scarcity of money. But, if the majority of those who get recruited are volunteers - coming in mainly on compassionate grounds-money would no longer be an issue. In short, many volunteers could be involved in fighting the pandemic, motivated by compassion, without necessarily increasing the cost of fighting the disease proportionately. This is where FBOs like the SDA Church could help in advancing the fight against the pandemic.

But the question that arises is, given the advantages of having as many people as possible involved in fighting HIV/AIDS, why are there so few people who are engaged in it, FBOs included? It is crucial that a study be carried out to determine the factors preventing many more people, especially from FBOs, who should have compassion like their Master Jesus exhibited during His earthly ministry, from getting involved. That will be the task of this chapter.

The study described in this chapter was carried out using two key social research methods, vis-à-vis, indirect participant observation and survey. The chapter is organized as follows: the section immediately following the introduction describes the indirectparticipant-observer situations, followed by a description of a survey carried out of members of two Adventist churches in Lusaka. The final section gives an overview of findings of the study, followed by a conclusion. 


\section{Indirect-Participant-Observer Cases}

Indirect-participant-observation has been defined as the participation or involvement, voluntary or otherwise, of a researcher in a situation that in some way throws valuable information on a subject of particular interest to the researcher (Malungo, 2010). Johann Mouton (2001) classifies participant observation studies under ethnographic research. Though this method has the limitations of lacking generalizability of its results and the potential bias of the researcher, its strengths include providing indepth insights and having high construct validity (pp. 148,149). Renowned Zambian HIV/AIDS researcher and strategist J. R. S. Malungo (2005) made good use of this method in his study of the sexual behavior of the valley Tonga of Zambia (Malungo, 2005, pp. 41-66).

The present author also found himself in such situations which now throw some very helpful insights into the underlying beliefs and attitudes members of the SDA Church hold regarding HIV/AIDS. Three such cases are described below and will serve as indirect-participant-observer situations for this study. A brief description of each one of the three follows below, and as suggested earlier, the reactions of the people involved in each case reflect some very deeply imbedded attitudes and beliefs about the pandemic. What do these instances reveal about HIV/AIDS stigma in the SDA church?

\section{Why Does Not Our Church Discipline AIDS Patients?}

The first case took place in 1993 while the researcher was serving as district pastor. What happened to him and his wife on their first Sabbath at church in a new district and what would follow exposed the attitude of some members in the Church concerning HIV/AIDS and those who are affected by it. On that Sabbath, the researcher 
and his wife met a very committed middle-aged lady at the church entrance. The Sister stopped them in order to greet them although she was not one of the ushers. After welcoming them to the new district and church, and without any warning, she blurted out, "Pastor, why does our Church treat HIV patients as if they were eggs?" To that the researcher responded, trying hard to conceal his surprise, "What do you mean by that?"

With an air of authority the sister explained: "I feel we are not helping the situation. Church members who get AIDS do so because they broke the law of God. Therefore, instead of petting them as if they were innocent little babies, why don't we first drop them from church membership, to register the church's displeasure on them for breaking the law of God? But instead of doing that, what do we do? We treat them like they were the most special people in the church! Pastor, that's why this disease is growing, even in the church! And that's why as you begin you work here as our new pastor, some of us would like to know what your position on this crucial issue is?" In utter shock, the researcher could only manage to ask her: "And supposing we followed the course you are suggesting, who would we be helping?"

Undaunted, our member came back: "Dropping them from membership would serve to cleanse the name of the church and at the same time teach those who break the law of God just how serious it is to violate God's will."

Wanting not to give in easily, the researcher countered: "But are we not already dropping those for whom doing so is the appropriate thing to do? And yet, even that has not stopped church members from breaking the law of God, has it? Is it not a sobering reality to lament that even before the advent of HIV/AIDS, the most common business 
our church board and business meetings were dealing with was dropping members from membership for violating the law of God?"

What a way to be welcomed to a new parish! But as shocking as that encounter was to the researcher and his family, it was perhaps a fitting welcome because during the 9 months that they served there, they would have several encounters with members suffering from the deadly disease. Unfortunately for them, ARVs were not known of or known at the time in Zambia.

This member's denial of what was so obvious was perhaps as shocking as was her charge that the Church was too lenient to those infected by HIV/AIDS. This came out when the researcher and his wife visited this member to console her after the death of the second of her daughters from AIDS. As we ended our short service and were preparing to leave, our member plainly and openly denied that her children's demise had anything to do with HIV/AIDS.

The grieving Sister put her sentiments in a very striking and unforgettable manner: "Pastor and Mrs., thank you for coming to see us. But, I want you to know that the Lord is very good to me. Each one of my daughters, who has died, died still with their full bodies, not emaciated like others whom I have seen. They have died and we will miss them, but not from AIDS!"

Our member represents an attitude that is so pervasive in the church, but which few have the courage to voice out like our Sister did. Therefore, as repulsive as her attitude may sound to be-and it truly was-she must be commended for voicing out what many others hide. 
Since that incidence in those early days in my ministry, I have over the years witnessed the death of not only four siblings of mine due to HIV/AIDS, but also of fellow church members, and of ministerial colleagues as well. But what has struck me so much is that the amount of denial with my siblings (the majority of whom were not even Adventists) was almost the same as what I witnessed amongst my fellow church members and ministerial counterparts. Of the many who succumbed to the opportunistic diseases characteristic of HIV/AIDS, two are worthy of even brief mention because they also constitute participant observer situations that help to reveal salient attitudes about HIV/AIDS.

\section{Two Sisters, Two Different Stories}

One was an African female church member who was having an illicit relationship with a Caucasian business man in the town where I was serving as a minister. So bad was the situation that the Caucasian man's marriage was on the brink of collapse. Her case was giving the church very negative publicity in the town. And it was a glaring case of HIV/AIDS.

My wife and I went to visit this member in the hospital. As soon as she saw us, she said: "Pastor, I am glad that you have come. But I want you to know that God is with me; I can feel His presence just now. I can see Jesus." She died 2 days later! One hopes she truly was as close to the Lord Jesus as she claimed to be, and that she was so absorbed in Jesus as to have no time to lament about AIDS.

The other, also a lady, had a very different experience. When my wife and I arrived at her bedside in hospital, it was very clear that she did not have long to live. As soon as she saw us, she said: "Pastor, I am dying of this deadly disease, but I do not have 
even a single word of condemnation for or complaint against the Lord. I am the one to blame. It's the consequences of my choices. I wished I had always known what I now know. Perhaps things would be different!"

I had to struggle to hide the tears at the corners of my eyes, as I was moved to my very core. If I had the power to heal or if I were God, I would have healed her right there and then. But she also died a few days later. Touched by her spirit of openness, I preached a sermon at her funeral that led more than five of those who heard it to surrender their lives to Jesus, right there and then.

\section{My Unbelieving Brother Versus My Ministerial Colleagues}

The researcher also observed how some of his ministerial colleagues reacted to the reality of HIV/AIDS. The problems of denial and stigma were clearly at work. Out of four who had symptoms of HIV/AIDS only one is still alive today. This surviving one went for VCT to know his status, accepted the reality of his situation, and adhered to a strict regimen of ARVs. The other three died in denial or as result of negligent taking of ARVs.

Compare the above with the case of my immediate elder brother. A teacher by profession and a holder of a Bachelor of Science degree in Biochemistry, he became ill due to HIV/AIDS related opportunistic diseases. When we went to pick him from his school to bring him to a specialist who would put him on antiretroviral drugs (ARVs), after agreeing to come with us, he later changed his mind and adamantly refused to go anywhere. Later we came to learn that while we were in town to re-fuel for the trip, he had been paid a visit by a traditional healer who convinced him that he was being bewitched! And nothing we said thereafter could help change his mind. And yet, before 
he started manifesting the true symptoms of HIV/AIDS, my brother used to say for him, AIDS was just a question of time. My brother died a week later!

\section{Conclusion}

These incidences clearly establish that there is stigma regarding HIV/AIDS in the SDA Church. Also, it is clear that some of the members, ministers included, may not yet be as well informed about HIV/AIDS as they should be. Otherwise, the knowledge would have given them power (knowledge is power), as well as set them free (Jesus said, "You shall know the truth and the truth shall set you free," John 12:32). Further, there seems to be a tendency for Christians, especially those who perceive themselves to be very committed to God's work, to feel that all will be well even if, on their part, they neglect to do what they need to do to get well again.

In other words, such people tend to suffer from a false security syndrome-the feeling that because of their relationship, God will make up for what they are unwilling to do. Thus, ministers of religion and other outstanding Christians neglect to go for VCT, or if they go at all and are found to be positive, neglect to strictly adhere to medication. Of course another reason for this is that their high social standing means that knowledge of their status may spread quickly.

We turn next to the survey that was carried out to find out what SDA Church members think about their church's involvement in the fight against HIV/AIDS.

\section{Survey of SDA Members: Research Design and Methodology}

This section of the study describes the process followed to collect and analyze the views of SDA Church members on HIV/AIDS. The survey was designed around a descriptive and exploratory social research model that utilized quantitative and 
quantitative research techniques for data collection and analysis. By means of selfstructured questionnaires, SDA Church members were surveyed regarding the involvement of the Church in the fight against HIV/AIDS. Respondents for the study were drawn from two local church congregations in Lusaka, Zambia, out of the over hundred congregations in the city and its outlying areas, namely, Lusaka Central and Libala churches. The two churches were chosen not merely for their proximity to the researcher's work place, but especially for their reputation as the two most powerful SDA churches in Lusaka, the national capital of Zambia. One of them, (Central Church), due to its significant financial contribution, is regarded by some as the most powerful church in the whole country.

The sampling frame comprised of 102 SDA church members, between the age of 15 and 75 . The participants were largely from an urban background considering that both churches are city churches. In regard to education, all the participants in the survey were educated people in view of the fact that each one needed to be able to read and understand the questionnaire and answer the questions.

Also participants in the survey were picked either on the basis of their willingness to participate in the survey, or were randomly selected from among members of SDA Church present during worship on the day the survey was carried out. The surveys of the members from the two churches were conducted on the same Sabbath while the church services were in process. Additionally, there was a comparatively smaller sample of questionnaires which were given to a few randomly selected Mufulira mission district SDA church members who met for a fellowship in Mufulira, a mining city in the Copperbelt province of Zambia. This additional sample was carried out not only to get 
the views of SDA church members outside Lusaka, but also to augment the relatively small sample from Lusaka.

Questionnaires were distributed, 200 at Lusaka Central Church and 196 at Libala. Out of the 396 questionnaires given out, 94 were returned properly filled in; that is, 58 from Libala church and 36 from Central. We learned later that the reasons for the limited participation included the following: (a) the time given to participants to fill in the questionnaires at church on the day of the survey was not enough, (b) some people opted to take the forms home to get enough time to answer the questions, but failed to return them the following Sabbath when coming to church for worship, and (c) the survey questions were difficult for some. Thus, although the questionnaires were distributed on the same Sabbath, and under very similar circumstances, they were more positively attended to at Libala Church than at Lusaka Central.

As noted above, an additional eight questionnaires were given to eight randomly selected Mufulira mission district SDA church members who met for a fellowship in Mufulira in mid April 2010. Apart from the fact that the sample was relatively very small, every one of the eight participants filled in and returned their questionnaire forms. The additional eight raised the total number of participants to 102 .

In order to protect the confidentiality of the participants, participants were not required to write their names on the survey forms, thereby making it impossible for any of the responses to be connected to the names of the respondents. Nor were they to give any information that could in some way give a clue as to their true identity. Further, the questionnaires/surveys were distributed and collected through the leadership of the churches. 
The participants were requested to answer 17 questions. Appendix B is the actual survey instrument that was presented to all the participants, while the following tables summarize the participants' responses to all of these questions. Tables 1 and 2 reflect responses to the first two questions, which deal with how participants gained information concerning HIV/AIDS. Six of the questions required a simple yes or no response (questions 3, 5, 6, 15, 16, and 17) and three yes-no questions added not sure as an option (questions 10,11, and 12). The results of these questions are in Tables 3 and 4 , respectively. The remaining questions are presented in Tables 5 through 10 (questions 4 , $7,8,9,13$, and 14). 
Table 1

Summary of Response to Question 1

How did you first know about HIV/AIDS?

\begin{tabular}{lc}
\hline Options & Response (\%) \\
\hline Media & 59 \\
Work Place & 26 \\
School & 13 \\
Family/Friends & 2 \\
\hline
\end{tabular}

Table 2

Summary of Response to Question 2

What has been your greatest source of information about the pandemic?

\begin{tabular}{lc}
\hline Options & Response (\%) \\
\hline Media & 91 \\
Interaction with affected & 2 \\
Work place & 2 \\
School & 2 \\
Hospital/Clinic & 2 \\
Church & 1 \\
\hline
\end{tabular}


Table 3

Summary of Response to Questions 3, 5, 6, 15, 16, and 17

\begin{tabular}{clcc}
\hline \multirow{2}{*}{$\begin{array}{c}\text { Question } \\
\text { Number }\end{array}$} & \multicolumn{1}{c}{ Response (\%) } \\
\cline { 2 - 4 } & Questions & Yes & No \\
\hline 3 & Or have you ever attended a seminar on HIV/AIDS? & 80 & 20 \\
5 & Have any of your family members been affected by the disease? & 93 & 7 \\
6 & $\begin{array}{l}\text { As a member of the Seventh-day Adventist church, do you feel } \\
\text { that the church is adequately involved in the fight against this } \\
\text { deadly epidemic? }\end{array}$ & 17 & 83 \\
15 & $\begin{array}{l}\text { Are you as an individual very involved in this humanitarian } \\
\text { crisis threatening the existence of the human race today? }\end{array}$ & 67 & 33 \\
16 & $\begin{array}{l}\text { If a way was found through which you could participate in } \\
\text { alleviating the suffering caused by HIV/AIDS, would you be } \\
\text { willing to play a part? }\end{array}$ & 95 & 5 \\
17 & $\begin{array}{l}\text { Do you think that the church's involvement or lack of it in the } \\
\text { humanitarian crisis caused by HIV/AIDS, in one way or another, } \\
\text { affects its image with both its members and non-members? }\end{array}$ & 95 & 5 \\
\hline
\end{tabular}

Table 4

Summary of Response to Questions 10,11, and 12

\begin{tabular}{|c|c|c|c|c|}
\hline \multirow{2}{*}{$\begin{array}{l}\text { Question } \\
\text { Number } \\
\end{array}$} & \multirow[b]{2}{*}{ Questions } & \multicolumn{3}{|c|}{ Response (\%) } \\
\hline & & Yes & No & Not Sure \\
\hline 10 & $\begin{array}{l}\text { Do you think there is stigma against people living with } \\
\text { HIV/AIDS (PLWA) in the SDA church as well as other } \\
\text { churches? }\end{array}$ & 81 & 12 & 7 \\
\hline 11 & $\begin{array}{l}\text { From your experience, do you think that Adventists are } \\
\text { as well informed about HIV/AIDS as non SDAs? }\end{array}$ & 26 & 63 & 11 \\
\hline 12 & $\begin{array}{l}\text { Given the value Adventists attach to the law of God and } \\
\text { obedience to it, do you think there is any relationship } \\
\text { between the general apathy seen in the church towards } \\
\text { helping those affected by HIV/AIDS and the view that } \\
\text { the disease comes as a result of disobedience to God? }\end{array}$ & 81 & 13 & 6 \\
\hline
\end{tabular}


Table 5

Summary of Response to Question 4

As the saying goes, "you are either infected or affected." How has HIV/AIDS affected your life as an individual?

\begin{tabular}{lc}
\hline Options & Response (\%) \\
\hline Of a loved one & 62 \\
Death of a loved one & 27 \\
Workmates/friends & 8 \\
Personally affected & 2 \\
Both "of a loved one" and "death of a loved one" & 0 \\
\hline
\end{tabular}

Table 6

Summary of Response to Question 7

Why do you say that?

\begin{tabular}{lc}
\hline Options & Response (\%) \\
\hline Very rarely talked about & 53 \\
Leadership not concerned & 35 \\
No structured programs & 12 \\
\hline
\end{tabular}

Note: Question 7 asked the participant to clarify the main reason for their answer to question 6, which asked, "As a member of the Seventh-day Adventist church, do you feel that the church is adequately involved in the fight against this deadly epidemic?" Responses to question 6: $83 \%$ answered "No" and 17\% "Yes." 
Table 7

Summary of Response to Question 8

Compared to other religious organizations, how would you rate the involvement of the Seventh-day Adventist Church (SDA) in this humanitarian crisis?

\begin{tabular}{lc}
\hline Options & Response (\%) \\
\hline Negligible & 88 \\
Moderately & 13 \\
High & 7 \\
\hline
\end{tabular}

Table 8

Summary of Response to Question 9

What could be some of the reasons for that?

\begin{tabular}{lc}
\hline Options & Response (\%) \\
\hline Pretence that SDAs are not affected & 36 \\
Holier than thou attitude & 34 \\
No orphanages/hospices & 30 \\
\hline
\end{tabular}

Note: This question is related to question 8 , see Table 7 above. 
Table 9

Summary of Response to Question 13

As a believer in Christ, from what you know of Him, how would you expect Jesus to relate to PLWA, if He were alive today?

$\begin{array}{lll}\text { Options . } & \text { Response (\%) }\end{array}$

He would show them love and compassion 81

$\begin{array}{ll}\text { Not sure } & 19\end{array}$

Table 10

Summary of Response to Question 14

What do you think is God's will for the church today in regard to those suffering from HIV/AIDS?

\begin{tabular}{lc}
\hline Options & Response (\%) \\
\hline To show them love and compassion & 88 \\
Not sure & 12 \\
\hline
\end{tabular}


This is the picture that the survey of SDA members in two leading local congregations in Lusaka, namely Lusaka Central and Libala, in connection with the AIDS pandemic reveals. As mentioned earlier on, the particular congregations were selected because they represent the most influential and largest membership, respectively. But, what do these findings tell us? What is their significance? And how do they relate to the goal of this study? A summary and analysis of the survey findings is taken up in the following section.

\section{Findings of the Survey}

Though the survey questionnaires were 17 in total, the survey results may be summed up in 11 points. And as we will show in the discussion that follows, the survey confirms the pre-suppositions under-girding the study as articulated in the introductory chapter.

Graphic Descriptive Analysis of Questionnaire Findings

According to the survey there are a variety of sources from which people gather information regarding HIV/AIDS. My research revealed a variety of sources as communicated in figure 1 below.

AIDS impacts people in a variety of ways. Survey participants placed highest emphasis upon sickness of family members. Secondarily, the responses reported the impact of death followed by personal impact and impact upon workmates and friends outside of the immediate family. Figure 2 reveals a graph that compares these four impact areas. 


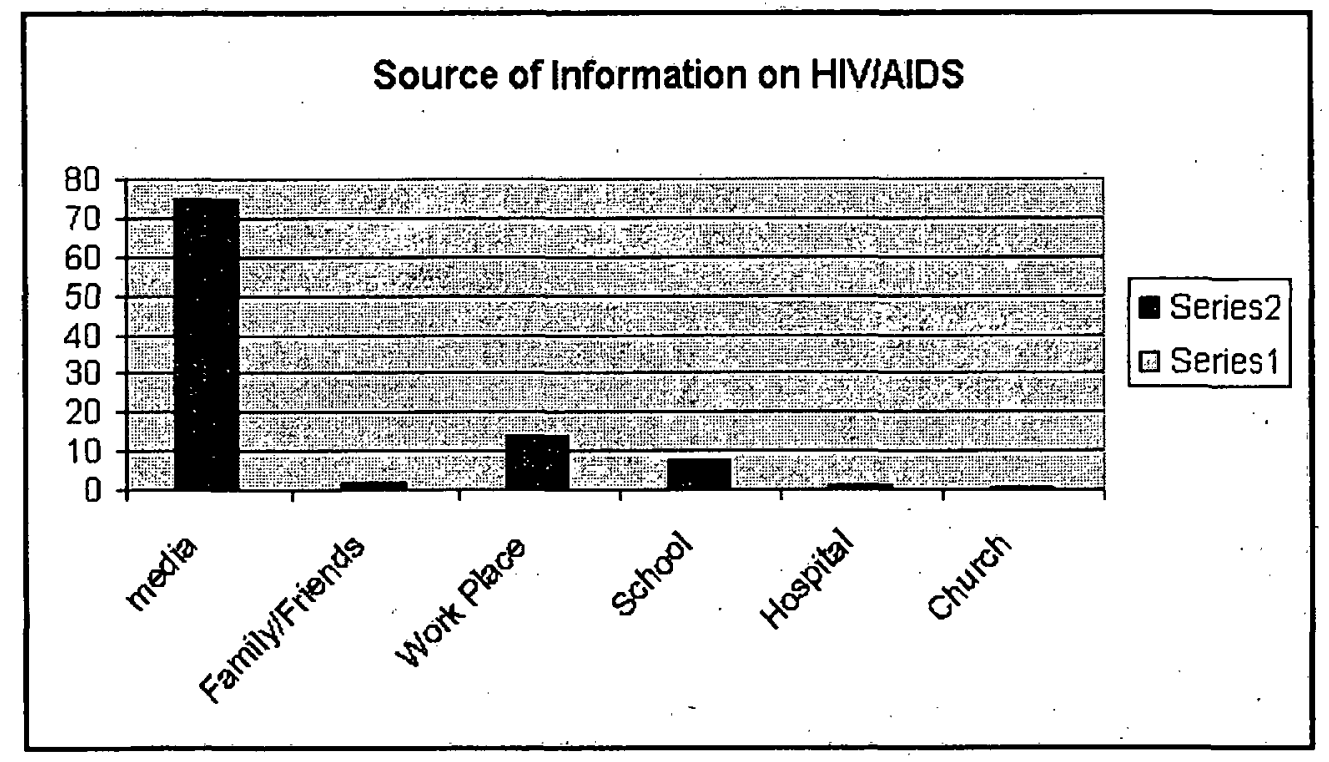

Figure 1: Sources of information about HIV/AIDS

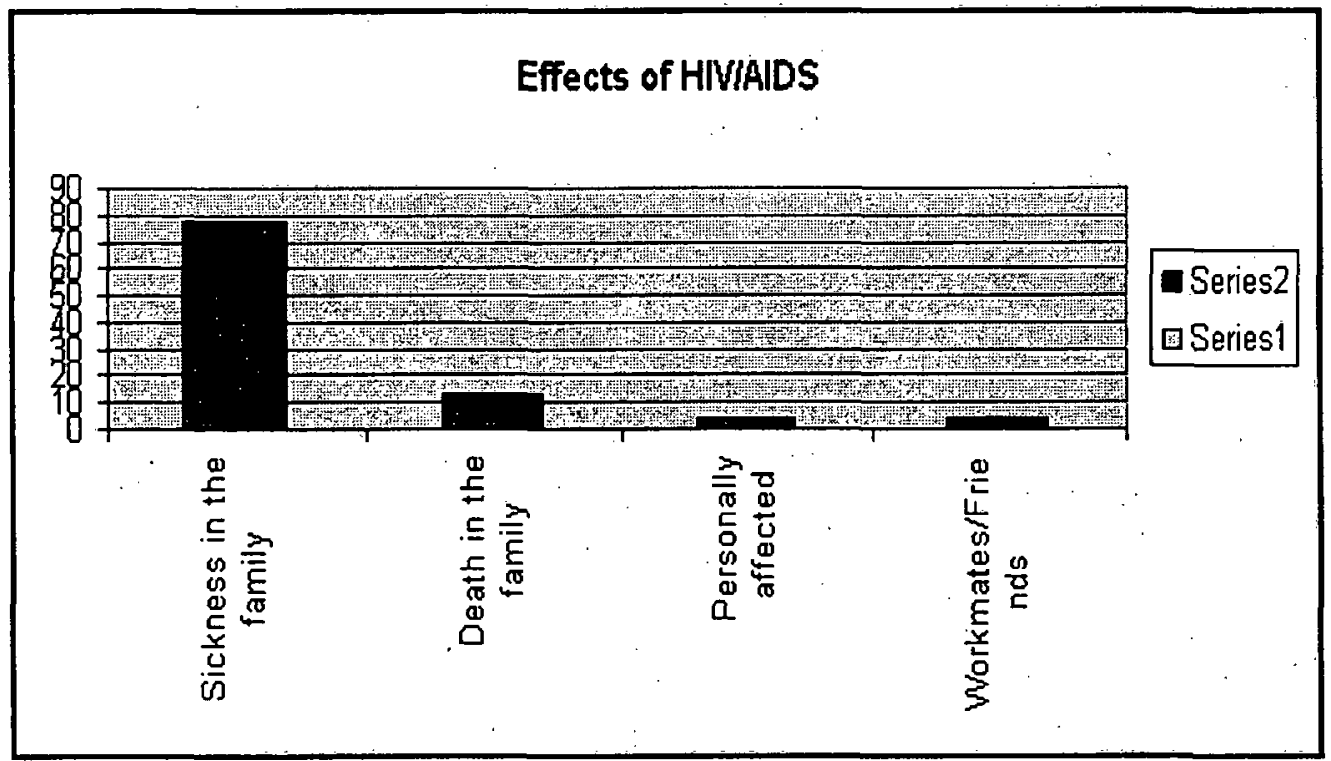

Figure 2: Effect of HIV/AIDS 
Are SDA believers willing to be involved in fighting AIDS? The churches surveyed reported the percentage of member's involvement in work to reduce or halt the advance of HIV/AIDS as reported in figure 3 below.

The report of churches members indicates a perception that their church leaders were involved at an unacceptable level. Figure 4 below shares the feedback gathered by the questionnaire.

The questionnaire also measured whether members sensed the existence of negative stigma in the SDA Church regarding those suffering from HIV/AIDS. Figure 5 below reports these findings.

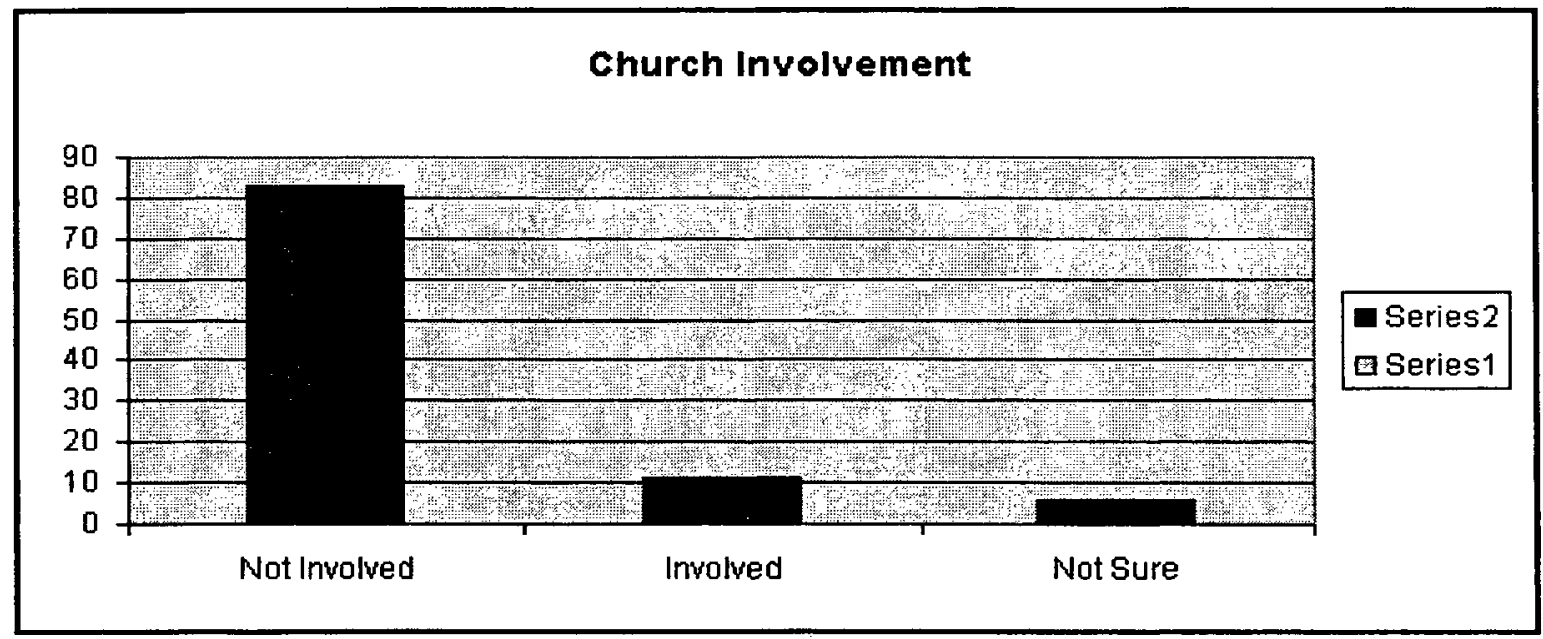

Figure 3: Percentage of membership involved in combating HIV/AIDS 


\section{Church Leadership Involvement}

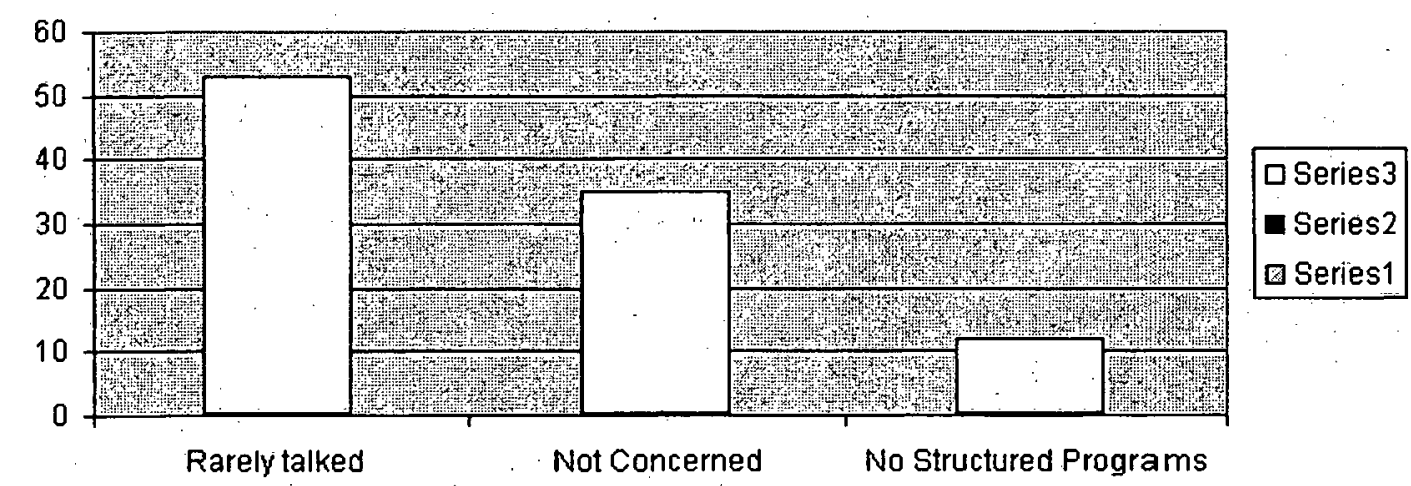

Figure 4: Degree to which members perceive leaders to be involved in the effort to combat HIV/AIDS

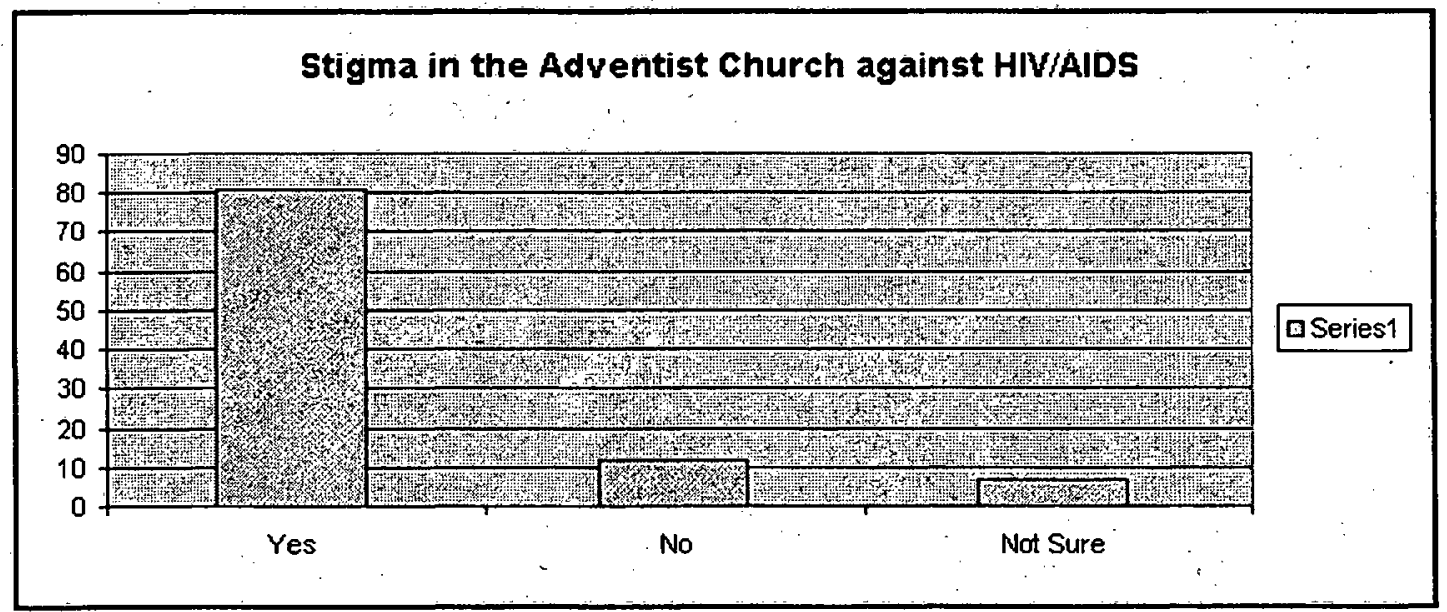

Figure 5: Members stigmatize those suffering from HIV/AIDS 
Figure 6 reveals the findings regarding whether or not members of the churches surveyed would be willing to participate in humanitarian efforts to stem the advance of HIV/AIDS in their communities.

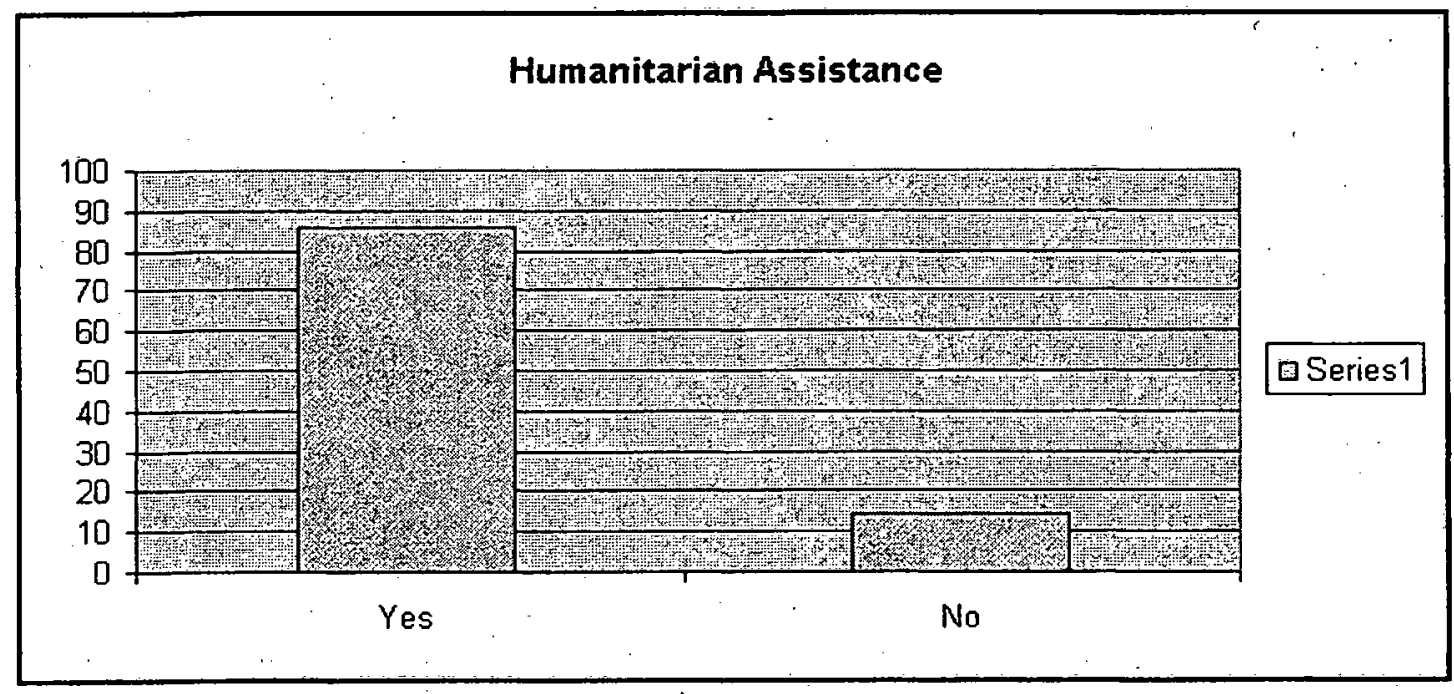

Figure 6: Members willingness to provide humanitarian assistance to HIV/AIDS Victims

\section{Implications of the Survey Findings}

As suggested earlier on, the survey results may be summed up in eleven points whose implications include but may not be limited to the following:

1. The survey reveals that the media plays a very critical role in the dissemination of information about the pandemic.

2. SDA church members, like everyone else, are affected and infected by HIV/AIDS.

3. The survey reveals that many SDA church members believe that the denomination is not sufficiently involved in the fight against this deadly disease. Eightythree percent of the participants said that the church is not adequately involved, and only 
$11 \%$ said it was. The fact is further supported by the fact that asked to compare the involvement of the SDA Church in the fight in comparison with other denominations on a scale of $1-10$, where 1 represents the least and 10 the highest, an overwhelming $88 \%$ rated the church between 1 and 5 .

4. The study also reveals that church members believe there is still stigma against HIV/AIDS and PLWAs in the SDA Church. Of those who responded to the survey, $81 \%$ admitted that stigma exists in the church, while $12 \%$ denied its existence, and the remaining $7 \%$ were not sure. HIV/AIDS is a complex disease that includes a (ACSA, 2005, p. 6)

5. The research also reveals that SDAs are very well informed about HIV/AIDS. Sixty-three percent of the respondents said that Adventists are as knowledgeable about the disease. Only $26 \%$ said SDAs do not have enough knowledge about HIV/AIDS, and the remaining $11 \%$ could not commit themselves to one view or the other.

The revelation that SDAs are not ignorant about HIV/AIDS is consistent with the fact that $80 \%$ of the participants reported that they had attended a seminar on the pandemic, and only $20 \%$ denied ever attending one. Therefore, while many of the respondents lamented the fact that there is very little teaching about HIV/AIDS going on in the church, the fact is that many Adventists know about the disease, either through the media or seminars about HIV and AIDS.

The revelation that many SDA believers know a lot about HIV and yet the Church is doing very little to teach the members should be a warning to the church leadership. A story is told of a man who used to procrastinate every time he felt that he needed to talk to his under-10 year old son about HIV/AIDS. One day when the man finally gathered 
enough courage to talk to his son, the young man sullenly asked: "AIDS, what do you want to know, daddy?"

6. Perhaps the most significant finding of the survey is that there is a relationship between the general apathy seen in the SDA Church towards assisting those affected by HIV/AIDS and the view that the disease comes mainly as a result of disobedience to God law. Asked whether such a relationship could be there, $81 \%$ of the participants answered in the affirmative, while only $14 \%$ denied such a relationship, and the remaining $5 \%$ were not sure. Such a connection would not be difficult to conceptualize given the SDA church's firm view that the law of God remains valid, and that God requires all His children to obey it.

7. The survey also reveals that most members of the SDA Church believe that if Jesus were alive today, He would treat HIV/AIDS patients with the same compassion $\mathrm{He}$ showed to lepers and others like them whom He came into contact with during His mission on earth.

8. Furthermore, SDA Church members are convinced that the church should also show compassion to HIV/AIDS patients today. Of the people involved in the survey, $81 \%$ said Jesus would be compassionate to those affected by AIDS were He alive today, while $88 \%$ said the church should deal compassionately with those affected today.

9. Another finding of the survey is that most SDAs are willing to be involved in the fight against HIV/AIDS. This is supported by the fact that although $34 \%$ of the questionnaire respondents said they were not in any way involved in fighting HIV/AIDS, $67 \%$ are willing to be involved in the fight. As a matter of fact, when asked directly whether they would be involved in the fight if a way through which they could be 
involved was found, $95 \%$ of the participants in the survey said yes. Only $5 \%$ were unwilling.

10. Also, the survey reveals that most SDAs are concerned that the church's non involvement in the fight against HIV/AIDS has a negative impact on its public image. Here also, $95 \%$ of the people surveyed felt this was the case and only $5 \%$ denied that this was the situation.

11. Finally, the survey shows that SDA members blame the aloofness of the church on the HIV/AIDS issue on the church's leadership as figure 4 shows. As support for their view, several survey participants cited lack of emphasis on the need for the church to be involved in HIV/AIDS alleviation programs. As figure 4 shows other reasons were also given.

\section{Analysis of Research Findings}

While the survey has revealed several things about how SDAs look at the unfolding HIV scenario, this analysis, due to limitation of space, will focus only those revelations that speak to the goals of the study. The rest will reflect in the strategy developed in Chapter 5 to address the crisis.

In the first place, the survey informs us that media plays a very crucial role in the dissemination of information about the HIV/AIDS pandemic. This is highlighted by the fact that $59 \%$ of all the respondents said they first got to know about the pandemic through the media. For Lusaka Central Church, the percentage was even higher, at 30 out of the 35 members who participated got their first knowledge of the pandemic from the electronic and print media, representing $86 \%$. At the same time, $91 \%$ regarded the media to be their greatest source of their information on the disease. 
This fact has been highlighted by previous studies, especially in connection with the youth. For example, James Gribble (2010), vice president of International Programs at the Population Reference Bureau, in an article entitled "Investing in Youth for National Development" points out that media is one the most effective ways of reaching youth with information about sexual and reproductive health (p. 4). Again Gribble (2010) reports that Helping Each Other Act Responsibly Together (HEART), an HIV and AIDS program initiative designed to teach abstinence to youths aged between 13 to 19 years in Zambia used several media in its anti-AIDS campaign such as television, radio, music, videos, posters and billboards to reach youth (pp. 4-5).

The significance of the survey revelation that most of those interviewed credited their knowledge of HIV/AIDS mainly to media lies in the fact that media is the most effective means of reaching youth with sexual and reproductive messages. And this connection is crucial because it is only through the education of youth that we can ever hope to contain the AIDS pandemic. As David Harrison (2005) points out, only a focus on teenagers and senior youths aged between $20-24$ years aimed at behavior change could provide the much needed "the tipping point" in the fight against in the disease; that is the point at which efforts to combat the epidemic begin to tip towards sustainable success (p. 259). Another organization involved in combating HIV using the media is Soul City, a South African health promotion organization. Working alongside other organizations, Soul City has successfully used the power of mass media to reach youth in addressing topics in an entertaining and informative manner (p. 257).

Another revelation from the survey was that SDA church members, like everyone else, are affected and infected by HIV/AIDS. Sixty-two percent of the participants in this 
survey indicated that they were affected by the pandemic through the death of a family member, while $91 \%$ reported having a relative who had either died of the disease or were suffering from it. These findings are supported by a recent study conducted in Lusaka, which determined the extent to which Adventist adolescents in Zambia engaged in premarital sex as well as to assess the extent to which Adventist youths could be exposed to HIV and other sexually transmitted infections. The study found that Adventist adolescents were sexually active due to the combined influence of peer pressure, and books and films that promoted illicit sex. Also, slightly over two thirds of sexual activities among Adventist adolescents did not involve the use of condoms. Thus, Adventist adolescents were found not only to be sexually active, but also at risk in regard to STIs and HIV infection (Muyunda, 2009, n.p.). This fact is also readily admitted by the Church administration:

AIDS is no respecter of national boundaries, church membership, gender, marital status, education, income, or position in life. In many countries of the world, it is decimating the population, taking the lives of many individuals, including Seventhday Adventist Church members. The global epidemic of AIDS profoundly impacts the worldwide gospel mission of the Seventh-day Adventist Church. (GC, 2010a n.p.)

As stated earlier, two of the goals of this study are (a) to establish the reasons for the perceived aloofness of many SDAs in Lusaka in the fight against HIV/AIDS and (b) to demonstrate that SDA Church members in Lusaka (and beyond), if given a proper understanding of Jesus' ministry of compassion and are rightly motivated and properly mobilized and organized, would willingly respond to the humanitarian crisis engendered by HIV/AIDS even on volunteer basis. The study began with the assumption that the SDA Church is not sufficiently involved in the fight against HIV/AIDS. One of the findings of this study is that this view is correct. 
According to result in Table 3 (question 17) above, $95 \%$ of the SDA members interviewed expressed that the church is not adequately involved in the fight against HIV/AIDS. But why do Adventists seem to be uninterested in such a critical humanitarian crisis? Why would an organization that is considered to be one of the most concerned about people's well being in the here and now, and is thus placed among the best as far as social involvement is concerned, now turn a blind eye when humanity is facing what could be its most critical problem?

The survey rules out ignorance as a possible cause. To the contrary, the survey has revealed that Adventists are very knowledgeable about AIDS. Though much of this knowledge is not obtained through the church, members, nonetheless, know a lot about the pandemic due to media and through attendance of seminars.

Similarly, the noncommittal stance the SDA church seems to have taken in the fight against HIV/AIDS is not because Adventist members are neither infected nor affected by the disease. Contrariwise, the research shows that true to the popular saying "everyone is either infected or affected," Adventists are both affected and infected like the rest. As pointed out above, Muyunda's study revealed that adolescent Adventists have their sexual debut quite early in their lives and that slightly over two thirds of sexual activities among Adventist adolescents did not involve the use of condoms. Hence, Muyunda (2009) concluded that Christian adolescents were found not only to be sexually active, but also at risk in regard to STIs and HIV infection (n.p.). We also referred to the admission of the SDA Church administration that:

AIDS is no respecter of national boundaries, church membership, gender, marital status, education, income, or position in life. In many countries of the world, it is decimating the population, taking the lives of many individuals, including Seventh- 
day Adventist Church members. The global epidemic of AIDS profoundly impacts the worldwide gospel mission of the Seventh-day Adventist Church. (GC, 2010a n.p.)

Therefore, the reason for the Adventist Church's finger tips involvement in, or uncaring stance towards, the HIV/AIDS crisis must be due to another cause besides lack of knowledge or Adventists not being affected by the pandemic. The survey seems to suggest this could be the result of deeply held stigma, which, in turn, is caused by a regrettable misunderstanding of the relationship between obedience to the law of God, on the one hand, and whether those who suffer because of breaking the law of God should be shown compassion.

It is a well known fact that Adventists passionately uphold obedience to God's Law. But what is not yet known is what impact such a high view of obedience could have in relation to those who are perceived to have brought suffering upon themselves through disobedience. While the view that whoever is HIV positive must have contracted the disease through promiscuousness is stigmatized, not factual and unfair, it is a confirmed fact that the primary method by which HIV is spread is through sexual relationships.

Therefore, in order to test the attitude of SDA members towards people affected by HIV and AIDS, participants in the survey were asked whether they thought there was any relationship between the general apathy seen in the SDA Church towards helping those affected by HIV/AIDS and the view that the disease comes as a result of disobedience to God. As Table 4 above shows, $81 \%$ said "Yes." This overwhelmingly held view clearly shows that there is stigma against HIV/AIDS and PLWAs in the SDA Church. This conclusion is supported by the revelation that $81 \%$ of the people who participated in the survey admitted that stigma exists in the church, with only $12 \%$ denying its existence, and the remaining $7 \%$ not being sure. 
However, as the literature review showed, Adventists are not the only ones struggling with stigma against PLWAs. In Chapter 3 mention was made of the ACSA communion which openly admitted the existence of this vice amongst its members and courageously went ahead to address the issue in a book.

Also, in a review of HIV/AIDS stigma in four countries, Ogden and Nyblade (2005) explored the root causes of individual perceptions of stigma. The multi-country study found that:

Although knowledge of ways HIV could be transmitted was high in general, there was a lack of understanding about how HIV could not be transmitted. This was found to be exacerbated by fear-based public messages and sensationalism. Perceptions of morality were linked to promiscuity, moral transgression, choosing to engage in 'bad' behavior, and punishment from God. Perceptions of relative guilt or innocence in relation to HIV infection were also referred to-for example, babies who were infected maternally, or health workers who were infected with HIV during the course of their work were seen as "innocent victims", whereas people who were infected through sexual intercourse were perceived as being "guilty"... as having brought the disease upon themselves.

Unfortunately, however, the direct effect of such a view is that it automatically excludes those who are perceived as having brought suffering upon themselves, and thus do not deserve compassion. The natural result is that those who feel this way cannot step in to help those who they feel deserve what they are going through.

But then, if believers in a benevolent deity get affected by a negative attitude like stigma, against the very people that their faith in the divine should lead them to empathize with, what would we expect of unbelievers?

One of the findings of the study confirms one of the premises undergirding this study: that SDA Church members in Lusaka (and beyond), if given a proper understanding of Jesus' ministry of compassion and if rightly motivated and properly mobilized and organized, would willingly respond to the humanitarian crisis engendered 
by HIV/AIDS on a volunteer basis. Over $80 \%$ of those interviewed believed that Jesus had compassion on those suffering in His time (Table 9), and further that it is God's will that the Church should show mercy to HIV/AIDS (Table 10). Further, 95\% would be willing to play a part in fighting HIV/AIDS if a way was found (Table 3). The survey also shows that most of the members blame leadership for remaining silent on such a critical social issue as AIDS.

\section{Summary and Conclusion}

The SDA Church is not actively involved in the fight against HIV/AIDS. This chapter of the study reports a survey that was carried out to establish the reasons for this surprising apathy. Of the many factors at play, the belief that the majority of those who get AIDS do so because of disobedience to God's revealed will is prominent. This view represses the feelings of compassion that would move believers to want to help. On a positive note, the study has also revealed that many SDA members believe that Christ would not only show love, care, and compassion to HIV/AIDS were He alive today, but expects the church to do likewise. The survey has also exposed the desire for many Adventists to be involved in mitigating the suffering caused by HIV/AIDS. There is a need then to devise a strategy by which to engage many SDA members in the fight against HIV/AIDS in a model of compassion. It seems that whatever the nature of the factors impeding the involvement of many more people in the fight against the HIV pandemic, compassion, as exemplified in the life and ministry of Jesus, is a very important and effective factor and has the potential to exponentially increase the number of people engaged in the fight, and thus drastically reduce the cost of such engagement, thereby making the fight against the HIV/AIDS pandemic sustainable. 


\section{CHAPTER 5}

\section{A STRATEGY TO ENGAGE SDA CHURCH MEMBERS \\ IN THE FIGHT AGAINST HIV/AIDS}

\section{Introduction}

The last chapter focused on a survey conducted in two leading SDA churches in Lusaka and one outlying area in order to unveil the expectations of members of this denomination regarding the church's participation in the fight against HIV/AIDS. The two main objectives of the survey were (a) to determine the denomination's level of involvement in the fight against the disease, and (b) to establish the reasons for the denomination's perceived aloofness in the fight against the pandemic. However, the survey went beyond and made 11 key findings: (a) the media plays a very critical role in the dissemination of information about the pandemic; (b) SDA church members, like everyone else, are affected and infected by HIV/AIDS; (c) the SDA Church as a denomination is not sufficiently involved in the fight against this deadly disease; (d) there is still stigma against HIV/AIDS and PLWAs in the SDA Church; (e) SDAs are very well informed about HIV/AIDS; (f) there is indeed a relationship between the general apathy seen in the SDA Church as far as assisting those affected by HIV/AIDS is concerned, and the view that HIV/AIDS is mainly caused by disobedience to God's law; (g) many SDA church members believe that if Jesus were alive today, He would treat those infected and affected by HIV/AIDS with the same compassion He showed to lepers and others like 
them whom He came into contact with during His mission on earth; (h) the church should also show compassion to people affected or infected by HIV/AIDS today; (i) many SDAs are willing to be involved in the fight against HIV/AIDS; (j) the SDA Church's casual involvement in the fight against HIV/AIDS has a negative impact on its public image; and, finally, (k) SDA church members blame the perceived aloofness and silence of the denomination on the HIV/AIDS issue on the church's leadership.

Thus, the survey confirms that the SDA Church is not sufficiently involved in the crusade against HIV/AIDS. In addition, the survey explains why. Yet, why the SDA Church should be uninvolved in fighting the pandemic when knowledge about the pandemic abounds within the church is still puzzling. This is especially so considering that from its inception the SDA Church has been visibly involved in helping people fight disease and suffering through the establishment of clinics and hospitals. So, why should the SDA Church be comparatively unconcerned in combating a pandemic which is regarded as the greatest ever to befall the human race when all along it has been very concerned in alleviating human suffering?

The survey itself suggests why, with all the knowledge in the church about HIV/AIDS, there is still apathy regarding helping those affected by the disease-the revelation that there is widespread stigma in the church. The survey reveals that not only is stigma prevalent in the SDA Church but that the stigma is fanned and fueled by an unfortunate and regrettable doctrinal misunderstanding caused by failure to correctly relate obedience to God's law, on the one hand, and how to treat those who have failed to or chosen not to obey God's law, on the other. The survey has revealed that many Adventists think that since the most common way of contracting HIV/AIDS is by sexual 
contact, then the majority of those who have AIDS are reaping the results of disobedience. And quiet naturally, it is not possible for people who think this way to at the same time show compassion to those they look at this way. Hence the stigma in the SDA Church confirmed by the survey.

The prevalence of stigma in the SDA Church has a twofold impact on the church's involvement in fighting the pandemic. First, stigma makes the knowledge about HIV/AIDS of none effect, much like a Doctor who, though knowledgeable that smoking is dangerous to health, continues to smoke. Second, the prevalence of stigma not only negatively impacts the corporate will of the church to fight the pandemic, but also reduces the number of individual church members willing to engage in the fight. Yet, as stated earlier on, for the fight against the HIV/AIDS pandemic to become more cost effective, sustainable, and, therefore, more successful, many more people should be engaged in it than are currently involved in it. Furthermore, more and more volunteers should be solicited to engage in the fight on a no-pay-basis. This is in view of the fact that presently there are appeals not just for more money to be injected into the fight, but also for those countries supporting the fight thus far not to scale down their contributions (Thom, 2010). The involvement of volunteers, motivated by compassion would release the money spent on human helpers for use to procure more ARVs.

As Paul Shongwe (2008, n.p.) has aptly noted, "God calls the faithful to help all suffering people with compassion. The choice isn't whether or not to respond to the AIDS crisis; it's how to do so best." Similarly, former UN Secretary General, Kofi Anan blamed the comparatively little success in the fight against HIV/AIDS on "shortage of leadership and human compassion" (UNAIDS, 2005). Implied in these statements are 
two important facts, namely, (a) there is need to draw a strategy based upon compassion to be used in fighting HIV and (b) leadership should take the lead in developing such a strategy. The second deduction seems to be sustained by the fact participants in the survey blamed leadership for the general apathy in the church towards the fight against HIV/AIDS.

Yet, the SDA Church has not been silent on the HIV/AIDS pandemic. It has produced several official documents stating its position on the pandemic. Ironically, most church members at the local church level still think that the church is silent or unconcerned about AIDS. Consequently, while the church condemns stigma in whatever form, we have evidence that stigma is rife in the SDA Church. Undoubtedly, this is partly due to the fact that the information that would have helped reduce stigma remains largely unknown to the majority of the rank and file. Thus, we notice that the problem of information bottleneck that beleaguers the fight against the pandemic in general, also affects the SDA Church. Therefore, it is clear that the strategies have not filtered down to the grassroots. So, how can ordinary members of the SDA Church be motivated and organized to become actively engaged in the fight against the HIV/AIDS pandemic?

Because church members blame church leadership for the general apathy in the SDA Church towards the fight against the HIV/AIDS pandemic, it is necessary for leadership to propose a strategy by which to engage Adventist members in fighting the contemporary humanitarian crisis. That is what we turn to next.

\section{Organizing the Church for Compassionate Service}

The purpose of this chapter, therefore, is to propose a strategy by which to engage SDA members in the fight against HIV/AIDS on a voluntary basis. At the outset, the 
researcher is convinced that against the backdrop of the survey carried out in Chapter 4 which, among other things, revealed that many Adventists are willing to join the fight against the pandemic provided a method for them to participate is achievable.

The following principles should guide the formulation of a Christian intervention strategy to combat HIV/AIDS, and should be taught as part of the intervention strategy:

1. The church must stop being judgmental and spend more time in ministering to the HIV/AIDS sufferers. It is not a matter of choice but an obligation for Christians to be their brother's keepers and they are commanded to love one another (John 13:34; 15:12$13,17)$.

2. The church should play an intercessory role and pray on behalf of AIDS sufferers and also pray with them.

3. The church must listen and identify with PLWAs through passionate involvement in their lives; this means that church members need to open their hearts to and empathize with PLWAs.

4. The church needs to set up a strong visitation program to ensure that PLWAs should never feel lonely. The visitation program should be regular, and confidentiality must be maintained.

5. One of the worries of PLWAs is how they will provide for their families. Help must be given to the sufferers and practical assistance be given in providing for their needs. When we truly love one another (John 15:17) we will show fruit including giving of our material possessions.

6. In order to be effective the church ought to update its information on HIV/AIDS and to continually form strategies in association with the community in 
educating the youth. Public opinion of premarital sex must be influenced through education and chastity be strongly advocated.

7. While it may be true that AIDS is a very devastating disease that may quench all hope of recovery for those affected by it, the church, however, must always be there to give hope to the hopeless and thereby help them to cope with the disease.

The SDA Church is one of the most thoroughly organized church bodies in the world today. Its four constituent level organization moves from the individual believer at the local church to the worldwide church headquarters known as the General Conference. The organizations are the local church, the local conference, the Union conference, and the General Conference Association of Seventh-day Adventists (GC, 2005). Through this network, properly coordinated, programs may be channeled and implemented very effectively. Though programs and initiatives often flow from the highest level to the lowest, i.e., the local church, it is important to note that some of the programs voted are actually developed at the grassroots and recommended up -only to be recommended down to the rest of the church, after they had been proven effective in a local setting. The strategy includes mobilizing the community service wings of the church, visà-vis, Dorcas, Adventist Youth (AY) and Adventist Men organization (AMO) to be actively in the fight against the pandemic. To begin with, HIV/AIDS seminars will be conducted for these groups, either separately or together. Thereafter, each group will be encouraged to mobilize and organize its members to be actively engaged in the fight against the pandemic. Part of the activities will include the following: hospital and home visitations, including washing or cleaning up the sick, as well as mobilizing resources to 
help the needy. It must be admitted that some of this is already being done, but there is to be a deliberate scaling up and regularizing of these activities.

The strategy to be implemented in order to engage church members in the fight against HIV/AIDS is multi-pronged and includes, but is not limited to, the following.

1.Without prejudice extending the teaching and healing ministry of Christ, by engaging in efforts to reduce the risk of individuals acquiring AIDS, and compassionately and non judgmentally caring for all those affected when an individual suffers from AIDS.

2. Designating a person in each church level to be in charge of spearheading all efforts to respond to AIDS challenges through appropriate initiatives and cooperative efforts with other entities in the community or country at large as well as ensuring that personnel and financial resources are secured as may be needed.

3. Developing and managing AIDS education programs using the resource HIV/AIDS Guide when applicable. Programs should be contextualized for relevant cultural and linguistic needs and directed to the following: (a) to pastors through continuing education and ministerial meetings designed to equip pastors to deal with members touched by the AIDS crisis (pastors need information on prevention, compassionate ministry, and applied ecclesiastical functions such as conducting a funeral service for a person infected with AIDS); (b) to teachers as continuing education and inservice training with emphasis on conveying spiritual values and developing skills among youth for coping with sexual pressures; (c) to parents by their modeling a lifestyle that upholds Christian values, recognizing that marriage relations and any use of alcohol or other abusive substances has a direct negative effect on their children's sexual values and practices; (d) to church members through sermons, Sabbath School Bible Study Guides, 
premarital counseling and marriage-strengthening activities, seminars regarding AIDS, and educational curricula which provides information regarding sexuality in general and AIDS in particular; and (e) to communities by recognizing the opportunity for Christian witness and ministry in the community at large, providing appropriate community outreach, and participating in cooperative endeavors.

4. Protecting and strengthening marriage by (a) upholding the ideal of abstinence from premarital sex, (b) advocating premarital HIV testing for both potential partners as part of the church-based preparation for marriage, (c) elevating God's ideal for fidelity in marriage, and (d) recommending protective measures against sexually transmitted diseases, including HIV.

5. Intentionally transmitting Christian values to the next generation, recognizing that individual sexual values are established in youth. Priority should be given to providing accurate information, a forum for open discussion, and emphasis on the moral dimension of decision making regarding sexuality.

Thus, the strategy places a lot of emphasis on teaching. Though the survey shows that Adventists are not uninformed regarding HIV and AIDS, one of the often repeated points expressed in the survey was the concern that there is very little teaching done in the church on the subject; that one rarely hears a presentation on HIV/AIDS in the SDA Church. As contradictory as this may sound, the fact that there is still a lot of stigma in the church against HIV/AIDS is in itself evidence that there is need and room for teaching about HIV/AIDS in the church. This point is echoed by the SDA official statement on HIV and how the church should respond to it:

The global epidemic of AIDS profoundly impacts the worldwide gospel mission of the Seventh-day Adventist Church. Church leaders are called to respond through 
initiatives in education, prevention, and community service, and through personal acts of kindness to persons and families involved in the crisis. AIDS is no respecter of national boundaries, church membership, gender, marital status, education, income, or position in life. In many countries of the world, it is decimating the population, taking the lives of many individuals, including Seventh-day Adventist Church members. All persons, especially young people growing up in an era of moral laxity, need to be taught biblical principles regarding sexuality and God's design that sexual intimacy be experienced within the protection of the marriage covenant. Leadership should provide credible information to members--presented in their own language and sensitive to their own culture. (GC, 2010a)

The teaching should also include the basics on HIV/AIDS, such as, (a) what is stigma, its causes, and its effects; (b) Jesus' teachings and miracles, and what we learn from them; (c) Christian compassion and the Christian's social responsibility; as well as the Christian and his government; and (d) such topics as Bible prophecy, especially the mark of the Beast and Christian stewardship, and how these relate to donor funding which may be tapped into to mitigate human suffering or accelerate development.

Also, it is necessary to review the official pronouncements the SDA Church has made on HIV and AIDS and what is expected of its members (See appendices A, B and C). These official church documents lay out the foundational principles upon which an effective HIV/AIDS intervention strategy may be based.

One of these is the Adventist International AIDS Ministry (AIAM), a remarkable "ministry of the Seventh-day Adventist Church that brings hope, love and compassionate care and support to the people touched by the HIV epidemic. AIAM serves the territory of the sub-Saharan Africa and the Indian Ocean" (AIAM, 2009). The mission statement of AIAM is

to coordinate actions and resources to bring comfort, healing and hope to people infected and/or affected by HIV/AIDS, share a message of education and prevention to the general population, and present a united front in order to accomplish what our Lord Jesus Christ has commissioned each of us to do. (AIAM, 2009) 
The vision of AIAM is to create "Centres of Hope and Healing" through the church's network of local church congregations, medical and educational institutions, and church members. This is to be achieved by mobilizing churches through church based support groups, thereby bringing practical solutions to the infected and affected by HIV and AIDS.

Through AIAM the SDA Church plans to meet its social responsibility (SR) to the community in which it exists, a region worst hit by the HIV/AIDS pandemic, with the aim of creating a new generation free of AIDS! (AIAM, 2009). In a nutshell, AAIM (a) promotes programs to help churches become Centres of Hope and Healing (CHH); (b) equips and empowers (EE) churches to deal with the epidemic; (c) works through HIV prevention programs (HIV-PPs) to help reduce new infections, and to reduce the vulnerability of individuals and communities (VIC) to the epidemic; (d) provides CARE and SUPPORT (CS) for those infected and affected (IA) by the epidemic; and (e) promotes and implements Income Generating Activities and Skills Development Programs (IGASDPs) to help alleviate the socioeconomic and human impact of the epidemic (SHIE). In other words, AIAM is the SDA Church's strategy of practically applying the Gospel of Jesus-Christ, field by field, church by church, person by person, on a one to one basis in order to respond to the pain and suffering caused by HIV/AIDS today (AAIM, 2009).

One of the problems lamented by the participants in the survey, and which was cited as evidence of the SDA Church's negligible involvement in the fight against HIV and AIDS, was the fact that the church has no hospices or orphanages. While this is not exactly true because the church in Zambia operates an orphanage in Kabwe, two in 
Lusaka, and one or two in other locations, the fact that these are not well known like Adventist hospitals such as Mwami, Yuka, Eye Hospital, underscores the concern. In other words, if the SDA Church is operating significant hospices and orphanages, why have they not risen to the fame of the well known Adventist institutions, and why are many people going there?

Therefore, each Conference will be encouraged to challenge its churches and districts to develop such facilities, ensuring that these facilities are developed. To ensure that this is done, the Conferences/Fields will be encouraged to include the formation and operation of these institutions in their strategic plans and therefore factored into their annual budgets. And, as providence would have it to be, because of the sessions that we have just had, 2010 is the year for strategic planning because we have just come out of the union session and a new 5 year planning period lies ahead.

But the establishment and operation of hospices and orphanages raises the question of funding. In other words, where is the money for the set up and operation of these facilities to come from? This is a very important consideration, which even our Lord Jesus Christ was concerned about 2,000 years ago:

For which of you, intending to build a tower, sitteth not down first, and counteth the cost, whether he have sufficient to finish it? Lest haply, after he hath laid the foundation, and is not able to finish it, all that behold it begin to mock him, saying, This man began to build, and was not able to finish. (Luke 14:28-30)

According to one of the survey responses, many SDA church members think that the church has the money to put up and operate institutions such as orphanages and hospices, just like other denominations that are doing so already. They feel it is just a question of mixed priorities. This should not be surprising because, often, those on the outside - whether it is children in relation to their parents, or citizens with their political 
leaders or church members and their spiritual leaders-feel that money is there and priorities are just not set right; until they themselves sit on the same management boards only to discover, to their dismay, that as a matter of fact they did not understand the true financial standing of their organization.

So then, where shall the money for setting up and running these institutions come from, if the church does not have the money? Is this not the reason why the church has not put them up thus far?

We have earlier in this study advanced the view that the main reason why the church has not done as much in HIV/AIDS combatancy as in fighting other diseases is far more than just availability of resources. If that were the case, the church would, in the first place, have equally failed to put up the hospitals for which it has become proverbial today. Instead, the church struggled to raise funds for these institutions, against all odds to support such projects. More often than not, an unfaltering vision of the importance of the cause at hand, more than availability of means has kept the church committed to a project to its very completion.

The reason for the little support for the church's involvement in fighting HIV/AIDS has been shown to be stigma towards HIV/AIDS and PLWAs. This stigma is fed by the widely held view that HIV/AIDS is caused by sexual infidelity, which in turn is the result of disobedience to God's law. And given the importance that Adventists attach to obedience, those who are perceived as having disobeyed the law of God are almost unconsciously viewed as suffering the consequences of their own choices. Hence, the stigma that is prevalent in the church. 
However, HIV/AIDS stigma is not unique to the SDA Church alone: It is prevalent among other FBOs. As Deborah Dortzand and W. Meredith Long (2006) have suggested, the reason why many Christians did not bother to get involved in helping during the early years of the AIDS epidemic was because of stigma. Many of them, like Adventists, viewed AIDS as a disease mostly confined to gay people and drug users, and who, therefore, were suffering the consequences of their own sin. However, as AIDS has continued to ravage the lives of millions of people around the globe in the years since, Christians have finally taken notice--SDAs included.

So, what is the solution to the financial challenge accompanying the setting up of orphanages and hospices? Fortunately, the SDA Church in Zambia has had an experience that could answer this challenge.

The much publicized Lusaka Adventist Eye Hospital in Lusaka, built in only one year for a total of 1 million (U.S. dollars) was built using donated money from Operation Eyesight International of Canada (OEIC) and began operating with the sponsorship of Christoffel Blinden Mission of Germany (CBM). If the project had depended on SDA funding alone, it would not have taken off up to the present. But because of the partnership between the donor organizations, many people in Zambia who are not able to sponsor themselves to South Africa are able to recover their sight, support themselves and their families, as well as contribute to national development. Here is a way by which the resources needed to set up and operate the much needed hospices and orphanages may be secured for the SDA Church to run these facilities. And this view of forming partnerships is recognized as the only way to make progress in the fight against the deadly pandemic. As has been rightly pointed out, for us to win the fight against 
HIV/AIDS, we need to stand together; otherwise, we are sure to fail. Given its credibility with Government, the SDA Church stands a very good chance of attracting donor funding on a worthy cause like mitigating the effects of HIV/AIDS, save for what we will term the Beast Syndrome (BS).

The following article entitled "Potential Adventist Church-WHO Collaboration Looks Promising," which appeared in the 17th July 2009 issue of the Euroasia Division newsletter by Ansel Oliver (2009), may help to illustrate the meaning of this phenomenon. As the article attests, the 'beast syndrome' noted above is prevalent not only where the SDA church is conservative, (as it is in Africa), but also in the liberal West:

As Seventh-day Adventist Church officials move toward official relations with the World Health Organization (WHO), a United Nations agency, many church members said they think such a partnership would benefit the denomination's network of schools, hospitals and clinics.

But at last week's international conference to explore the possible collaboration, some Adventists said they aren't sure about the proposed partnership, citing concerns of blending politics with faith and compromising the church's spiritual values.

Still, leaders of both organizations said that working relations between the two organizations would give each better access to networks and resources as they seek to improve the health of local communities. Adventist leaders said the church's international network could help WHO better implement the U.N. Millennium Development Goals, including improving maternal health and fighting HIV/AIDS and malaria.

Last week's Global Conference on Health and Lifestyle in Geneva brought together representatives from WHO, the Pan American Health Organization and more than 600 leaders of the Adventist Church. While WHO has previously partnered with other faith-based organizations, this would be the first time it could extend official relations to a church denomination. The conference approved an action statement that will be submitted to the world church's Executive Committee, which is scheduled to meet in October. (n.p.)

Here was a very rare and epoch making opportunity for the SDA Church, accorded to no other denomination ever. Yet some members were not very excited about it, for fear that a partnership such as this one could have the potential of making the 
church a political organization and, thus to compromise its Christian standing. Under girding these concerns, however, is the fear that the church's unique prophetic identity and role may be compromised and lost. But it must be pointed out that cardinal to this prophetic understanding is the view that the enemy to the true church is the Beast, the enemy of God and truth, who is ever seeking to beguile the church through his sophistry and craft (Rev chaps. 12;13;14; Dan 7:7-25). Hence, the appellation the Beast Syndrome- the fear that the beast of bible prophecy, through his sophistry and craft, may beguile the church from her fidelity to God, and that the church should, therefore, ever be skeptical of any dealings whatsoever with any organizations which are not SDAreligious or political.

However, there is no need for the church to be sidetracked because of a few very vocal and hypercritical elements in its midst. The SDA Church officially recognizes the need to cooperate with other stakeholders in the fight against the HIV/AIDS pandemic, as well as others humanitarian issues. That is why as far as the need for the Church to be involved in fighting the AIDS pandemic, the Church categorically states that "the love and compassion that characterized the life of Jesus sets an example for all His followers in their relationship with others" (GC, 2010a). Also, because the Church realizes the need to join hands with other stakeholders on common social evils, the General Conference the SDA headquarters, this year (2010) issued its official statement condemning violence against women and children categorically which in part states: "The Seventh-day Adventist Church seeks and welcomes partnerships and collaboration with others in addressing this global issue" (GC, 2010b). 
Additionally, the church in the Republic of Zambia, as indicated above, already has a very good name running institutions that were raised on funds that were not internally sourced. There is also the concept of harvest ingathering which the church has used from its earliest days to fund projects such as hospitals. In fact, the support of church projects using funds sourced from non Adventist source is based on the universal ownership of all things by God and the implied stewardship of not just all believers, but all humankind. The Lord Jesus employed this principle in His ministry when He sent out two of His disciples to a man, who was not one of His disciples, to ask for a house where He and His disciples could celebrate the Lord's Supper (Matt 26:17-19).

The church should promote the involvement of as many church members as possible in the operation of the hospices and orphanages, which would be established and run at the local church level. However, the moneys would be sourced by local churches or districts by means of applications channeled through their appropriate Conferences or Fields.

\section{Monitoring and Evaluation}

Any program that is worth the time put into it in planning for it should include a method by which it will be evaluated in order to determine its level of success. For this reason, almost without exception, it is now common practice for organizations to include monitoring and evaluation (M\&E) in all their strategic planning. Regularly scheduled evaluations help identify the challenges hindering the implementation of the project and the smooth delivery of services.

We have seen in this chapter that the SDA Church is concerned about and is deeply involved in fighting the HIV/AIDS pandemic. However, the powerful documents 
it produced on the pandemic, as well as the initiatives it devised to fight the same remain largely unknown, not only to the public, but to its members as well. However, if there was an approved and well publicized M\&E mechanism included with the proposed strategy, the church would quickly have noted that its efforts were not reaching the grassroots, and done something about it.

Though he was not really addressing M\&E, Piot's (2006) statement that "the AIDS pandemic and its toll have outstripped the worst predictions" and that there is, therefore, need to "mount a response commensurate with the challenge of stopping and reversing it," and that because the pandemic and its toll cannot be reversed in the short term, we need to sustain a full-scale response for the next decades so that each intervention, plan, and program established today must become the building block for longer-term, sustainable strategies to free the world of AIDS," (n.p.) in our view, underscores the significance of evaluating all proposed HIV/AIDS intervention strategies so ensure their success. Indeed, given the devastating nature of the disease every intervention strategy must succeed. And considering that the statistics of people "infected or affected by AIDS are not mere numbers, but represent real human beings" would it not be more humane and, therefore, better that we evaluate whatever strategy set in operation to ensure that it succeeds?

The M\&E for the strategy to engage SDA Church members in the two specified Lusaka churches in fighting HIV and AIDS will consist of the following.

1. On a quarterly basis, the Board members of each of the two churches will go through this report. The report will then be sent to the Conference office through the church/district pastor. The report will then be reviewed by the Conference committee and 
then submitted to the Union. At the Union, similar scrutiny will be made of the same, before passing it to the Division.

2. Each level will take appropriate action as well as recommend to the next higher level what may be inappropriate for it.

Appendix $C$ contains the $M \& E$ instrument for assessing the effectiveness of the proposed strategy.

\section{Summary and Conclusion}

While the previous chapter suggests that the SDA Church is passively watching the HIV/AIDS crisis, it must be clear from the foregoing that the SDA Church is neither silent nor unconcerned. On the contrary, this chapter has adduced evidence that the church is very concerned, and that it is doing something about it. The reason why many members think that the church is idly watching only attests to the existence of the information bottleneck that has been identified as inhibiting the fight against the pandemic. To address this problem, as well as to show the "love and compassion that characterized the earthly life of Jesus," and which is to be "the example for all His followers and in their relationships with others" (GC, 2010), this chapter has proposed a practical strategy by means of which ordinary church members may be involved in fighting the pandemic. The success of this proposed strategy depends not so much on the novelty of its proposal, but on the expressed desire of SDA members to be involved in the fight against the epidemic. Also, when church members see their leaders visibly involved, many of them will desire to be involved. Also, the strategy is embodied in the structure of the church. In this way, it is easy to follow up and evaluate its implementation on an on-going basis. Finally, the proposed involvement of the SDA 
Church in fighting the AIDS pandemic is a response to a felt need. That fact alone almost guarantees the plan's positive reception not only by members, but the public as well. However, the greatest strength of the strategy is that it is based primarily on compassion, which (a) is limitless and not on the vagaries of fiduciary gain and (b) imposes no limit to the number of people who can be involved in the fight against the pandemic. 


\section{CHAPTER 6}

\section{SUMMARY, CONCLUSION, AND RECOMMENDATIONS}

\section{Introduction}

Entitled "A Strategy to Mobilize Seventh-day Adventist Church in Lusaka in Response to the HIV/AIDS Crisis," this project comprises of 6 chapters. The first chapter serves as the introduction to the study, while the second through the fifth make up the body, and the sixth concludes the study. The organization of this final chapter, therefore, shall also follow this logical arrangement of the chapters. The section gives a summary of the entire study, chapter by chapter, followed by the conclusion. The final section of the chapter makes some recommendations based on the findings of the study.

\section{Summary}

Chapter 1 of this study introduced the purpose of the study by drawing attention to the fact that, while the HIV/AIDS situation in Lusaka, the Capital city of Zambia, has reached crisis proportions, there are more than 85,000 SDA churches members who are practically uninvolved in the fight against the pandemic. But, for a church that is well known for its involvement in issues affecting society—as exemplified by the hospitals and schools that it operates around the country - this scenario is not only regrettable but puzzling as well. For this reason, this negligence needed to be investigated. Thus, Chapter 1 confirmed the need to investigate the reasons for the perceived aloofness of the SDA Church in the contemporary fight against HIV/AIDS. 
The next target was determine whether there are any sound theological grounds for an FBO to be involved in community issues like HIV/AIDS. Without such a basis, those calling for the involvement of FBOs, like the SDA Church, could merely be giving in to socio-political pressure to support humanitarian issues in order to gain political favors, or even to allure new members to join their churches. Chapter 2 took care of such concerns by examining the life and ministry of Jesus, the prime Example for all believers, for any clues that could guide a religious organization as to how best to relate to suffering in throughout all the ages, including our own times. The chapter examined instances from both Jesus' teaching and healing ministry in order to discover principles that may be used today to deal with the HIV/AIDS pandemic. Three instances of Jesus working miracles of healing were examined closely; namely, Jesus' healing of the leper, the paralytic dropped through the roof and the invalid by the pool in Bethesda. The chapter also reviewed two parables Jesus narrated; namely, the parables of the Last Judgment and the Good Samaritan. The investigation revealed that Jesus was always moved by compassion to heal those who were suffering, irrespective of whether a person contributed to their illness or not. Hence, the investigation revealed Jesus' attitude towards human suffering, gave clues about how He would relate to human suffering today in the face of the deadly HIV/AIDS epidemic.

In this way then, Chapter 2 laid the theological foundation for Christian involvement in the contemporary fight against HIV/AIDS, suggesting that Christians should also, propelled by the same compassion Jesus manifested in His life and ministry, be as earnest in mitigating the suffering of those affected by AIDS as Jesus was in healing the sick when He was on earth. 
In an effort to establish the reasons why members of an FBO like the SDA Church would shy away from the fight against the HIV and AIDS pandemic, a literature review of the available literature on AIDS was conducted in Chapter 3. The review, among other things, brought out the fact that though the fight against HIV/AIDS is now nearly 30 years old; it is clearly far from being over due to the many challenges facing it. Among the challenges hampering the fight against the HIV and AIDS suggested by the review were (a) failure to take people's social contexts into account, (b) the failure to identify new challenges and to devise appropriate responses to them, (c) limited personnel and funding, (d) information bottlenecks, (e) implementation gaps, (f) stigma, (g) ignorance, (h) resistance to behavioral change or prevention, and (i) lack of compassion on the part of those involved in the fight, to name only a few.

Also, the literature established the need for social networks and the need for the involvement of more people the fight against the pandemic. However, except for an occasional mention here and there, especially in connection with FBOs, not much said about compassion. The general impression one gets from the review is that compassion is not regarded to be a very important factor in the fight against the pandemic. However, as Chapter 2 has shown, the power of compassion, as demonstrated in the life and ministry of Jesus, is a very powerful force.

Thus, overall, the literature review pointed to the critical need for unified action in fighting the pandemic, the formation of strategic partnerships and for more and more people to get involved in the fight against pandemic.

Because Chapter 1 suggested that the SDA Church is not actively involved in the fight against HIV/AIDS and Chapter 2 showed that Jesus compassionately healed 
suffering people during His ministry, there was need to establish the reasons for the perceived aloofness of the church in the fight against the pandemic. Therefore, Chapter 4 of the study described a survey that was carried out in order to establish the reasons for this surprising apathy. Of the many factors at play, the belief that the majority of those who get AIDS do so because of disobedience to God's revealed will was found to be very widely held. This regrettable view was traced back to a misunderstanding of how God considers sinners. Unfortunately, such a view has the double effect of not only quenching the compassion of those thinking thus, but also serving as the springboard of stigma. Hence, the stigma that the survey confirmed as existing in the Church was traced back to this unfortunate judgmental spirit based upon a mistaken notion of Jesus' attitude towards those supposed to have brought suffering upon themselves.

On a positive note, however, Chapter 4 revealed that many SDA members believe that Christ would not only show love, care, and compassion to HIV/AIDS were He alive today, but that He expects the church to do likewise. Similarly, the survey also revealed that many Adventists believers wish to be actively involved in mitigating the suffering caused by HIV/AIDS. Chapter 4 therefore pointed to the need for the development of a strategy by which many SDA volunteers could join the fight against AIDS.

Such a strategy would not only help increase knowledge about the pandemic, but help solve the ever growing problem of information bottlenecks. Such a strategy would also increase the number of educators and car-givers, thus lightening the burden of the already burdened activists. Finally, such a strategy would help reduce stigma. That was the function of Chapter 5 . 
Thus, Chapter 5 proposed a strategy entitled, "A Strategy to Engage SDA Church Members in the Fight against HIV/AIDS" (SESDA_AIDS). Whereas the survey feedback in Chapter 4 suggested that the SDA Church is passively watching the HIV/AIDS crisis, Chapter 5 dispelt such a notion. To the contrary, the chapter adduced evidence that the SDA Church is very concerned about and doing something about it. The strength of the proposed strategy was based on the expressed desire of SDA members to be involved in the fight against the epidemic. The M\&E instrument for the same is outlined in the chapter as well. The strength of the proposed strategy was based on the expressed desire of SDA members to be involved in the fight against the epidemic. Again, the strategy is embodied in the structure of the church, thus making it easy to follow up and evaluate its implementation on an on-going basis. Finally, the proposed involvement of the SDA Church in fighting the AIDS pandemic is a response to a felt need. This fact alone almost guarantees the proposed strategy's positive reception not only by members, but the public as well. However, the greatest strength of the strategy is that it is based primarily on compassion, which (a) is limitless and not on the vagaries of fiduciary gain and (b) imposes no limit to the number of people who can be involved in the fight against the pandemic.

\section{Conclusion}

Jesus' teaching and example show that it is not necessary to put a rift between preaching the Word of God and doing works of mercy. Doing so is not only contrary to Christ's example during His earthly ministry, but is also contrary to His teaching. Thus, combining preaching with works of charity is not an option, but a divine imperative. This chapter, therefore, has established that it is not only proper for Christians to be involved 
in alleviating and mitigating all human suffering, but a divine duty. To do otherwise is to deny Christ.

Hence, if the church will follow the ministry and example of Jesus, as the Body of Christ on earth, she would do more than allow non-FBOs to help in resolving the "shortage of compassion and human leadership" that Annan (2006) and others deeply involved in fighting the pandemic complain of, and thereby help to accelerate the fight against the HIV/AIDS pandemic. Further, by being so engaged, the church would identify with its master, Jesus, who during His earthly ministry always "moved by compassion" whenever He saw those who were afflicted. In other words, if Christians are following the example of Jesus, there is no way they can idly watch the suffering that is all around without being propelled by compassion to do something to help those who are affected. To do otherwise is to deny Christ. And, as Paul Shongwe (2008) warns, the Church will forfeit her credibility if she ignores the plight of the needy and condones social injustices. Could it be that the involvement of many Christians in the fight against HIV/AIDS on compassionate grounds may be the missing ingredient needed to spur the fight to a higher level?

\section{Recommendations}

Based on this study, the following recommendations are made.

1. Each local church should elect an HIV/AIDS Coordinator, and where that may not be feasible, the Health Ministries Director should give special attention to this role.

2. Each local Conference should elect an HIV/AIDS Coordinator; where that may not be feasible, let the Health Ministries Director give special attention to this role. 
3. Each local church should administer the Survey, "The Involvement of the SDA Church in the Fight against the HIV/AIDS Pandemic" on a quarterly basis.

4. Churches should be encouraged to set up and run hospices and to encourage families to adopt children genuinely orphaned by AIDS.

5. Each church to run a "Ministry of Hope for People Living With AIDS (PLWA) Seminar" each quarter.

6. More research should be done on compassion and how it can impact the fight against HIV and AIDS.

7. Local churches are encouraged to encourage members to consider circumcision as both an HIV/AIDS intervention as well as a general male health measure.

8. More study should be done on the use of condoms among FBOs.

9. More research should be carried out on HIV in the SDA Church. Doing so will help not only to bring more awareness among Adventists but engage the Adventist Church in the fight against the pandemic. One area that urgently needs to be investigated is the relationship between the high number of members that are dropped from membership because of failure to keep the 7th commandment and the incidence of HIV/AIDS among Adventists. In this regard, Muyunda is to be commended for his recent study entitled "Factors Associated With Early Sexual Behaviour Among Young Adventist Adolescents in Zambia" (2009), which among other things, revealed that Adventist young people engage in early sexual intimacy due to peer pressure. 
APPENDIX A

\section{QUESTIONNAIRE/SURVEY}

1. How did you first know about HIV/AIDS?
a. Media
b. Family/Friends
c. Work Place
d. School

2. What has been your greatest source of information about the pandemic?
a. Media
b. Interaction with affected
c. Work place
d. School
e. Hospital/Clinic
f. Church

3. Or have you ever attended a seminar on HIV/AIDS?
a. No
b. Yes

4. As the saying goes, "you are either infected or affected." How has HIV/AIDS affected your life as an individual?
a. Sickness of a loved one
b. Death of a loved one
c. Both a. and b. above
d. Personally affected
e. Workmates/friends

5. Have any of your family members been affected by the disease?
a. Yes
b. No.

6. As a member of the Seventh-day Adventist Church, do you feel that the church is adequately involved in the fight against this deadly epidemic?
a. No
b. Yes

7. Why do you say that?

a. Very rarely talked about

b. Leadership not concerned

c. No structured programs

8. Compared to other religious organizations, how would you rate the involvement of the Seventh-day Adventist (SDA) Church in this humanitarian crisis?

a. Negligible 
b. Moderately

c. High

9. What could be some of the reasons for that?

a. No orphanages/hospices

b. Holier than thou attitude

c. Pretence that SDAs are not affected

10. Do you think there is stigma against people living with HIV/AIDS (PLWA) in the SDA church as well as other churches?
a. Yes
b. No.
c. Not sure

11. From your experience, do you think that Adventists are as well informed about HIV/AIDS as non SDAs?
a. No
b. Yes
c. Not sure

12. Given the value Adventists attach to the law of God and obedience to it, do you think there is any relationship between the general apathy seen in the church towards helping those affected by HIV/AIDS and the view that the disease comes as a result of disobedience to God?
a. Yes
b. No.
c. Not Sure

13. As a believer in Christ, from what you know of Him, how would you expect Jesus to relate to PLWA, if He were alive today?

a. He would show them love and compassion

b. Not sure

14. What do you think is God's will for the church today in regard to those suffering from HIV/AIDS?

a. To show them love and compassion

b. Not sure

15. Are you as an individual very involved in this humanitarian crisis threatening the existence of the human race today?
a. Yes
b. No

16. If a way was found through which you could participate in alleviating the suffering caused by HIV/AIDS, would you be willing to play a part?
a. Yes
b. No.

17. Do you think that the church's involvement or lack of it in the humanitarian crisis caused by HIV/AIDS, in one way or another, affects its image with both its members and non-members?
a. Yes
b. No 


\section{APPENDIX B \\ LOCAL CHURCH MONITORING AND \\ EVALUATION INSTRUMENT}

Local Church Monitoring and Evaluation (M\&E) Instrument for "The Strategy to Engage SDA Church Members in the Fight Against HIV/AIDS" (SESDA_AIDS).

1. Is there an official specifically designated to spearhead the SESDA_AIDS program?

2. Is the officer responsible for SESDA at the local church the Health Ministries Director, or an HIV/AIDS coordinator for the church?

3. Is there an Elder specifically charged with the responsibility of working with either the Health Ministries Director, or the local church HIV/AIDS coordinator?

4. Where an HIV/AIDS coordinator is chosen, what collaboration or relationship is there between this officer and the Health Ministries Director?

5 . Is there a quarterly for review this quarter?

6. If not, why not?

7. How many sermons presented this quarter touched on HIV/AIDS?

8. How many Bible Studies presented during the quarter were on HIV/AIDS?

9. Do members feel free to declare their status in the church? Did any church members openly declare their status to be positive this quarter?

10. Is there stigma on HIV/AIDS and PLWA in the church?

11. Were there any presentations made on stigma and what it means for Christians?

12. Did the local church participate or initiate any HIV/AIDS awareness or alleviation activity this quarter?

13. Does the church have a regular hospital visitation program?

14. How many visitations were made this quarter?

15. Does the church (alone or in conjunction with other churches in the district) operate an orphanage or have families who have HIV/AIDS orphans?

16. What visibility has the church on HIV/AIDS issues?

17. Is an offering collected quarterly to assist those affected or infected by AIDS? 
18. Does the church run a hospice or is it planning to operate one in conjunction with sister churches?

19. Does the church participate in celebrating World AIDS Day on December 1, annually?

20. What plans are there for this year's program?

21. What do members say about their church's attitude and involvement in the HIV/AIDS pandemic?

22. Was the Survey on the Involvement of the SDA Church in the fight against the HIV/AIDS pandemic administered this quarter?

23. Are there any marked differences between the responses this quarter and last quarter?

24. In which areas does the local church need to improve?

25. Which areas does the Church Board need to bring to the attention of (a) the membership, (b) the local Conference?

26. Are members open to VCT?

27. How many VCT Sundays were made available to members this quarter?

28. How many members actually went for VCT this quarter? 


\section{APPENDIX C}

\section{SDA CHURCH AIDS EPIDEMIC GUIDELINES}

\section{Rationale}

The global epidemic of AIDS profoundly impacts the worldwide gospel mission of the Seventh-day Adventist Church. Church leaders are called to respond through initiatives in education, prevention, and community service, and through personal acts of kindness to persons and families involved in the crisis. AIDS is no respecter of national boundaries, church membership, gender, marital status, education, income, or position in life. In many countries of the world, it is decimating the population, taking the lives of many individuals, including Seventh-day Adventist Church members. All persons, especially young people growing up in an era of moral laxity, need to be taught biblical principles regarding sexuality and God's design that sexual intimacy be experienced within the protection of the marriage covenant. Leadership should provide credible information to members - presented in their own language and sensitive to their own culture. The Church is called to be both a prophetic and a compassionate voice-the mouthpiece and hands of God as it extends the ministry of Christ into the community.

The global mission of the Church, in reaching out to all races and peoples, draws into church fellowship many who are infected by the AIDS virus prior to joining the church or who are affected by having family members with AIDS. The epidemic is of such magnitude that no family will ultimately remain untouched. Many are infected through no action of their own. A judgmental attitude is always inappropriate, especially since the source of the infection cannot be determined with certainty. Many have experienced shame, fear, and agony as family members suffered and died with AIDS, often feeling compelled to secrecy regarding their painful situation. Just as Christ came to offer healing to a suffering world, so Seventh-day Adventists are commissioned to compassionately care for those who suffer and are affected with the virus of AIDS. Members can safely serve as care givers, at home or in health care facilities, if they are educated in appropriate ways of doing so.

\section{Recommendations}

The Seventh-day Adventist Church recognizes its Christian responsibility to respond to the global AIDS crisis and its devastating effect on humanity and wishes to respond in multiple ways which include:

6. Extending the teaching and healing ministry of Christ, who without prejudice cared for all in need, by engaging in efforts to reduce the risk of individuals acquiring 
AIDS, and compassionately and non judgmentally caring for all those affected when an individual suffers from AIDS.

7. Designating a person in each division, along with such personnel and financial resources as may be secured, to respond to AIDS challenges through appropriate initiatives and cooperative efforts with other entities in the community or country at large.

8. Developing and managing AIDS education programs using the resource HIV/AIDS Guide when applicable.* Programs should be contextualized for relevant cultural and linguistic needs and directed to:

a. Pastors: Through continuing education and ministerial meetings designed to equip pastors to deal with members touched by the AIDS crisis. Pastors need information on prevention, compassionate ministry, and applied ecclesiastical functions such as conducting a funeral service for a person infected with AIDS.

b. Teachers: As continuing education and in-service training with emphasis on conveying spiritual values and developing skills among youth for coping with sexual pressures.

c. Parents: By their modeling a lifestyle that upholds Christian values, recognizing that marriage relations and any use of alcohol or other abusive substances has a direct negative effect on their children's sexual values and practices.

d. Church members: Through sermons, Sabbath School Bible Study Guides, premarital counseling and marriage-strengthening activities, seminars regarding AIDS, and educational curricula which provides information regarding sexuality in general and AIDS in particular.

e. Communities: By recognizing the opportunity for Christian witness and ministry in the community at large, providing appropriate community outreach, and participating in cooperative endeavors.

9. Protecting and strengthening marriage by:

a. Upholding the ideal of abstinence from premarital sex.

b. Advocating premarital HIV testing for both potential partners as part of the church-based preparation for marriage.

c. Elevating God's ideal for fidelity in marriage.

d. Recommending protective measures against sexually transmitted diseases, including HIV.

10. Intentionally transmitting Christian values to the next generation, recognizing that individual sexual values are established in youth. Priority should be given to providing accurate information, a forum for open discussion, and emphasis on the moral dimension of decision making regarding sexuality.

Provided by the Health and Temperance Department, General Conference of Seventh-day Adventists, in cooperation with the General Conference AIDS Study Commission members. Copyright $\mathbb{C}$ 2010, General Conference of Seventh-day Adventists ${ }^{\circledR}$

12501 Old Columbia Pike, Silver Spring, MD 20904, USA 301-680-6000 


\section{APPENDIX D}

\section{AIDS-A SEVENTH-DAY ADVENTIST RESPONSE}

\section{Introduction}

AIDS (acquired immunodeficiency syndrome) looms larger every week. We are afraid for ourselves and for our families. We worry when we see no vaccine or cure in sight for years to come. Above all, wanting to be strong we feel helpless in the face of something that is becoming the plague of our lifetime.

How will Seventh-day Adventists respond to this global crisis? How will our church administration, educational system, medical system, and local churches respond? How will individuals respond? By their response to the AIDS epidemic, Seventh-day Adventists demonstrate their mission and purpose. We must question: "Does our mission and purpose closely reveal the face and heart of God as reflected in the life and actions of Jesus Christ?" Desiring to reveal the redemptive love of Christ we need to separate the disease from the issue of morality, demonstrating a compassionate, positive attitude toward persons with AIDS, offering acceptance and love, and providing for their physical and spiritual needs. We should feel ashamed when we see social rejection of people who have AIDS.

We must be adequately informed as to the dangers of AIDS and how it is spread. We must use that information to protect ourselves as well as share with others the information on prevention.

\section{What is AIDS?}

AIDS is a contagious disease caused by a virus called the human immunodeficiency virus (HIV). The virus enters the blood and disables a vital part of the body's immune system. This leaves the body unable to defend itself against a wide variety of infections and certain kinds of cancers.

Medical science is working intensely to combat AIDS. Some medications delay the onset of AIDS and others prove effective against some of the infections which persons with AIDS acquire, but to date there is no vaccine or cure for AIDS and none is likely in the near future.

\section{What are the Symptoms of AIDS?}

Shortly after acquiring the virus, humans can transmit the disease although they feel fine and have no symptoms. The commonly used blood test for the virus remains negative for two to six months after initial contact and in rare cases, more than 12 months. After the blood test for the virus becomes positive, people usually continue to remain symptom free for several years. During this incubation period they can continue 
to spread the virus to others. AIDS usually develops within five to fifteen years of first acquiring the infection. As of 1990 it seems that almost everyone infected with HIV will eventually develop symptoms and die of this disease.

An intermediate stage of the infection called AIDS-Related Complex (ARC) shows itself in a variety of symptoms, including: loss of appetite, drastic weight loss, fever, skin rashes, swollen lymph nodes, diarrhea, night sweats, fatigue and weakness. Affected persons may die from ARC without developing the specific infections associated with AIDS. People with AIDS commonly suffer repeated bouts of illness, many due to infections. These may be marked by pneumonia; severe infections of the mouth, throat or bowels; diarrhea; weight loss; prolonged fever; and unusual cancers. The virus can also attack the nervous system and damage the brain, causing loss of memory and coordination, profound weakness and personality changes.

\section{Global Impact of AIDS}

AIDS has been reported in nearly every country of the world. During the 1980's AIDS became an international pandemic, the number of persons with symptoms doubling every 18 to 24 months. Some people are calling AIDS the "plague" of the twentieth century. It is estimated that as many as seven million people are carrying the virus in 1990. At the present, however, well known diseases such as malaria, schistosomiasis and measles afflict and kill far more people worldwide than AIDS does. Yet AIDS remains a major threat to public health in most parts of the world.

The World Health Organization believes that by the beginning of the twenty-first century more than 100 million people around the world will be infected by the virus. One specialist in epidemics, Dr. B. Frank Polk of Johns Hopkins University in the United States, says that some countries may lose $25 \%$ of their population to AIDS by the mid1990 's.

\section{Can AIDS Be Treated?}

Drugs, such as zidovudine (AZT) effectively slow the progression of AIDS. Many additional drugs are in various stages of testing and may be released in the near future. While awaiting better HIV drugs, patients are treated for the specific infections or cancers as they develop.

Medical treatment in the United States for a person with AIDS costs an average of $\$ 40-60,000$ a year. The prevalence of AIDS is straining the capacity of medical facilities in many parts of the world. The expense of treating AIDS threatens to overwhelm the health care system in even the wealthiest countries.

\section{How People Do and Do Not Get Aids}

AIDS is spread most often through sexual contact. Infected men or women pass it on to partners of either sex. Because the AIDS virus is carried in the blood, it can be transmitted when IV drug users share needles and syringes, by transfusions of infected blood or blood products and by improperly sterilized hypodermic needles. Instruments used for tattooing, ear piercing, cutting tribal scars or penetrating the skin for any purpose can also carry the organism. Mothers can pass it on to children through pregnancy and/or delivery and, rarely, through nursing. 
AIDS is not casually spread. AIDS is not transmitted by shaking hands, touching, hugging or being close to people who have AIDS so long as there is no sexual contact or contact with blood. It is not caught by touching door knobs, using telephones, eating out in restaurants, swimming in public pools, using public toilets or through the ordinance of foot washing or baptism. Although the AIDS virus is found in very low concentrations in tears, nasal secretions and saliva, it is not easily transmitted by sneezing, coughing or casual contact. It is not transmitted by mosquito or insect bites or by contact with animals. It cannot be contracted by donating blood.

\section{AIDS and the Worldwide Work of Seventh-day Adventists}

The Seventh-day Adventist Church, because of its far reaching ministry in nearly 200 countries, will encounter the challenges posed by AIDS. Seventh-day Adventist leaders in all institutions and in the local congregations must actively educate for the prevention of HIV infection.

The Seventh-day Adventist Church is committed to meeting the challenge of AIDS comprehensively and compassionately. The General Conference formed an AIDS Committee in 1987. It is composed of experts in medicine, public health, nursing, church administration, minority interests, ethics, theology and education. Its recommendations must be acted on by the church's executive committees and boards if the church is to have a balanced, comprehensive and timely approach to AIDS.

\section{AIDS and Pastoral Ministry}

AIDS challenges the ministry of Seventh-day Adventist pastors and chaplains. They already have people with HIV infection in their congregations, communities and hospitals. The numbers will increase. They should not fear casual physical contact including shaking hands and baptizing. Pastors should continue to call on the sick at their homes or in the hospital. HIV infections should not change patterns of visitation or in any way limit ministry.

The AIDS crisis provides pastors and chaplains the opportunity to speak publicly about AIDS, sexuality, the sanctity and beauty of marriage, interpersonal relationships, and about health practices which provide a barrier against acquiring AIDS. In advocating and educating regarding behaviors that prevent the transmission of HIV, pastors and chaplains demonstrate the love and compassion of God in their Seventh-day Adventist ministry.

\section{AIDS and Pastoral Care}

The fear of AIDS should not compromise our compassion or our witness. Those who test positive for HIV and who may be sick with the disease should find acceptance and fellowship in the local congregation. They should be comfortable in our church services and be welcomed to participate in all activities of the church: baptism, foot washing and the communion supper. The local church can find many ways to minister to those with AIDS. Church members can join or form a support group and become individually involved in a supportive role to meet the needs of persons and families impacted by AIDS. 


\section{AIDS and Seventh-day Adventist Schools}

The HIV infected child must be welcome in Seventh-day Adventist schools even as God welcomes us into a relationship with Him. AIDS predisposes to others infectious diseases such as tuberculoses. If these are present proper precautions may be necessary confidentiality of students who test positive for HIV must be protected. Parents and teachers should be educated as to the nature of AIDS and the steps required to prevent its spread. Guidelines for educational institutions and a recommended curriculum for AIDS education is available through the General Conference Education Department.

\section{AIDS and Seventh-day Adventist Health Care Institutions}

Seventh-day Adventist hospitals and clinics should provide an environment in which AIDS patients receive compassionate, quality care. At the same time procedures and policies need to be implemented for the safety of employees to minimize any careless exposure to the AIDS virus. All needles, syringes and surgical equipment must be adequately sterilized. Blood and blood products should be tested and made as safe as possible. Guidelines for preventing AIDS in medical institutions are available through the General Conference Health and Temperance Department.

\section{AIDS and International Workers}

Workers assigned to fields outside of their homeland are receiving special training for the medical problems in the countries where they will be serving. These workers are receiving AIDS education. The church is advocating that travelers avoid injections where oral substitutes are available. They are advised to carry sterile disposable needles and syringes for their own personal use when injections are necessary, and they are advised to avoid transfusions of untested blood or blood products.

\section{A Final Word about AIDS}

Seventh-day Adventist church members and employees have a Christian obligation to respond to and treat people suffering with AIDS as Jesus our Savior treated the sick and outcast. Tragically, the world responds to AIDS sufferers as it once did to lepers--as sinful carriers of death to be shunned and isolated. But God in Jesus gave us His response. He went out of His way, often walking for several days, just to touch and heal a person afflicted with leprosy. He always offered love, acceptance and forgiveness to those afflicted by religious pride and other sins of the day. Through His redemptive love He offered life and freedom from the burden of sin. The Seventh-day Adventist Church seeks to engage in the ministry of Christ. It must respond with love and acceptance when dealing with all people, including those with AIDS.

\section{How to Prevent Aids}

- Limit sexual activity to a monogamous marriage relationship with a person known not to be infected with HIV. When one person is infected and sexual activities are continued, condoms are recommended.

- Use only sterilized needles or syringes for injections. 
- Test blood prior to transfusions.

- Sterilize sharp instruments used for scarification, tattoos and circumcision.

- Consult your doctor in the early stages of pregnancy.

- Educate other people about how to prevent AIDS.

- Choose to avoid high-risk behaviors such as sexual promiscuity and use of unsterile needles.

This study document was published by the AIDS Committee of the General Conference of Seventh-day Adventists, and was released by the Health and Temperance Department at the General Conference Session in Indianapolis, Indiana, 1990. 


\section{BIBLIOGRAPHY}

Abrahams, Lanaine (2005). Music changes minds. In V. Rockey (Ed.), The CSI handbook (pp. 192-193). Cape Town: Trialogue.

Adventist AIDS International Ministry. (2004-2009). Fighting the epidemic. Johannesburg: Cramerview. Retreived from www.aidsministry.com.

AIDS Action Committee of Massachusetts. (2007). What is HIV and AIDS? Retrieved from http://www.aac.org.

Annan, K. (2006). Preface. In 2006 report on the global AIDS epidemic: A UNAIDS 10th anniversary special edition. Geneva, Switzerland: UNAIDS.

Anderson, R. S. (Ed.). (2000): Theological foundations for ministry. Edinburgh: T \& T Clark.

The Anglican Church in Southern Africa. (2006). The Nature and extent of HIV and AIDS-related stigma in the Anglican Church of the Province of Southern Africa: A Quantitative Study. Cape Town.

Atmore, E. (2005). Building community capacity: The ECD experience. In V. Rockey (Ed.), The CSI handbook, (pp. 242-249). Cape Town: Trialogue.

Berkow, R., Beers, M. H., Bogin, R. M., \& Fletcher, A. J. (Eds.). (1997). The Merck manual of medical information. Whitehouse Station, NJ: Merck \& Co.

Biblesoft. (1994), New exhaustive Strong's numbers and concordance with expanded Greek-Hebrew dictionary. [CD-ROM]. Seattle, WA: Biblesoft.

Biblesoft. (1996), International standard Bible encyclopaedia. [CD-ROM]. Seattle, WA: Biblesoft.

Biblesoft (2000), Thayer's Greek lexicon. [CD-ROM]. Seattle, WA: Biblesoft.

Blackaby, H. (1994), Experiencing God. Nashville, TN: Broadman and Human Publishers.

Booth, D. (2009, September). US envoy notes Zambia's progress in removing HIV/AIDS stigma. The Post, p.8. 
Caldwell, J. C., P Caldwell, J. Anarfi, A. Kofi, J. Ntozi, I. O. Orubuloye, J. Marck, W. Cosford, R. Colombo, and E. Holdings, (Eds.). (1999). Resistances to behavioral change to reduce HIV/AIDS infection in predominantly heterosexual epidemics in third world countries. Canberra, Australia: Health Transition Centre.

Campbell, C. (2005): Letting them die: Why HIV/AIDS prevention programs fail. Cape Town: Double Storey Books.

Churches Health Association of Zambia. (2006). Local community competence building toolkit: Human rights \& gender equality for the prevention of HIV and AIDS. Lusaka.

Colossians: Chapter 3. (1980). In F. D. Nichol (Ed.), The Seventh-day Adventist Bible Commentary. (7:209-215). Washington, DC: Review and Herald.

Colson, E. (2005). AIDS and behavioural change: Gwembe Valley, Zambia. In Mubanga E. Kashoki, Musonda Lemba, Philimon Ndubani, Anitha J. Menon, Venkatesh Seshamani and Stephen Banda (Eds.). African Social Research: HIV/AIDS and Primary Health Care in Zambia, Number 51 (pp. 1-19). Lusaka, Zambia: The University of Zambia Press.

Ephesians: Chapter 4. (1980). In F. D. Nichol (Ed.), The Seventh-day Adventist Bible Commentary. (6:1019-1029). Washington, DC: Review and Herald.

Garbus, L. (2003). Country AIDS analysis project: HIV in Zambia. AIDS Policy Research Center, University of California San Francisco.

Garland, J., \& Blyth, M. (2005). Aids is real and it's in our church. Bukuru, Nigeria: African Christian Textbooks.

General Conference of Seventh-day Adventists (2010a). AIDS epidemic guidelines Washington, D.C.: Review \& Herald.

General Conference of Seventh-day Adventists (2010b). Statement on violence against women. Washington, D.C.: Review \& Herald.

General Conference of Seventh-day Adventists (2010c). Church Manual. Washington, D.C.: Review \& Herald.

General Conference of Seventh-day Adventists (2010d). AIDS-A Seventh-day Adventist Response. Washington, D.C.: Review \& Herald.

Government of the Republic of Zambia. (2003). Central Statistical Office: Census 2000. Lusaka: Government Printers.

Government of the Republic of Zambia. (2006). Zambia round 8 HIV proposal. Lusaka: Government Printers. 
Government of the Republic of Zambia (2008). Zambia Country Report: Multi-sectoral AIDS response monitoring and evaluation biennial report 2008 submitted to the United Nations Special Assembly on AIDS. Lusaka, Zambia: Government Printers.

Government of the Republic of Zambia. (2010), National AIDS strategic framework 2011-2015. Lusaka: Government Printers.

Gribble, J. (2010, January). Investing in youth for national development. In Policy Brief (pp. 2-7). Washington, DC: Population Reference Bureau.

Harrison, D. (2005). Growing the AIDS-free youth bubble. In V. Rockey (Ed.), The CSI handbook (pp. 256-259). Cape Town: Trialogue.

Health Transition Centre. (1999). Resistances to behavioral change to reduce HIV/AIDS infection in predominantly heterosexual epidemics in Third World Countries. Canbera: National University of Australia.

Hiebert, P. (1994). Anthropological reflections on missiological issues. Grand Rapids, MI: Baker Books.

Ho, A. (2005). Healthy lifestyle message. In V. Rockey (Ed.), The CSI handbook (pp. 154-155). Cape Town: Trialogue.

Jeasons, T. H., \& Basinger, R. B. (2000). Growing givers' hearts: Treating fundraising as ministry. San Francisco, CA: Jossey-Bass.

Joseph, A., \& Kouassi, N. (2005). Mainstreaming HIV and AIDS in sectors and programmes: A guide. Geneva: UNAIDS.

Lewin, Ruth. (2005). Health and HIV/ Aids. In V. Rockey (Ed.), The CSI handbook (p. 152). Cape Town: Trialogue.

MacDonald, W. (1995). Believer's Bible commentary: A complete Bible. Nashville, TN: Thomas Nelson.

Malungo, J. R. (2001). Premarital Sexual Behavior in Zambia: A case of the southern province. Zango: Zambian Journal of Contemporary Issues, 23(13), 45-71. Lusaka, Zambia: The University of Zambia.

Malungo, J. R. (2005). Emerging patterns of prostitution and sexual networking in Zambia: The risk of contracting HIV/AIDS and the demographic and socioeconomic implications. Pp.41-66 in African Social Research: HIV/AIDS and Primary Health Care in Zambia, Number 51. Mubanga E Kashoki, Musonda Lemba, Philimon Ndubani, Anitha J Menon, Venkatesh Seshamani and Stephen Banda (eds.). Lusaka, Zambia: The University of Zambia Press.

Malungo, J. R. (2010, May). Private conversation. Lusaka, Zambia. 
Mashale, R. (2005). Personal insight. Health and HIV/ Aids. In V. Rockey (Ed.), The CSI handbook (p. 152). Cape Town: Trialogue.

McNeal, R. (2000). A work of heart: Understanding how God shapes spiritual leaders. San Francisco, CA: Jossey-Bass.

Morgan, T., \& Stevens, T. (2005). Simply strategic volunteers: Empowering people for ministry. Loveland, CO: Group Publishing.

Muyunda, M. P. (2009). Factors associated with early sexual activity among Adventist adolescents in Zambia. Unpublished manuscript, Copperstone University NAC National HIV AIDS Strategic Framework.

Oliver, A. (2009, July 17). Potential Adventist church-WHO collaboration looks promising. Seventh-day Adventist Church Euro-Africa Division Newsletter. Retrieved from http://www.euroafrica.org/news/detail/datum/2009/07/17/ potential-adventist-church-who-collaboration-looks-promising/.

Paterson, G. (2005). AIDS related stigma: Thinking outside the box: The theological challenge. Switzerland: Ecumenical Advocacy Alliance and the World Council of Churches, Geneva.

Pienaar, Sunette (2005). It takes a community to raise a child: Thought Piece . In V. Rockey (Ed.), The CSI handbook (pp. 156-157). Cape Town: Trialogue.

Piot, P. (2006). Foreword. In 2006 report on the global AIDS epidemic: A UNAIDS 10th anniversary special edition. Geneva, Switzerland: UNAIDS.

Radebe, B. (2005). A bright future for vulnerable children. In V. Rockey (Ed.), The CSI handbook (pp. 167-169). Cape Town: Trialogue.

Raen, K. (2000). Where is the good Samaritan today? A challenge to fight HIV and AIDS. Nairobi: United Bible Societies.

Ratsara, P. (2008, May). Unpublished Sermon. Lusaka, Zambia.

Richardson, P. (2007). Field research for ministry. Unpublished class lecture, February. Cape Town, Western Cape, South Africa.

Shongwe, P. (1998). The mission of the church in South Africa in the light of the function and meaning according of John 13:31-16:33. Unpublished PhD dissertation, Rand Afrikaans University [now University of Johannesburg], Johannesburg.

Smith, D. L. (1992). A handbook of contemporary theology. Wheaton, IL: Victor Books.

Surowiecki, J. (2005). The wisdom of the crowds. New York: Anchor Books. 
Thom, A. (2010, May 27). Africa: ARV donor money running dry. allAfrica.com. Retrieved from http://allafrica.com/stories.

Torrance, T. F. (2000). Theological foundations. Edinburgh: T \& T Clark.

United Nations Development Programme. (2005). Mainstreaming HIV and AIDS in sectors and programmes: An implementation guide for national responses. Washington, D.C.: UNDP.

United Nations Programme on HIV/AIDS. (2000). Intensifying action against HIV/AIDS in Africa: Responding to a development crisis. Geneva, Switzerland: UNAIDS.

United Nations Programme on HIV/AIDS. (2003). HIV/AIDS and STI prevention and care in Rwandan refuge camps in the United Republic of Tanzania. Geneva, Switzerland: UNAIDS.

United Nations Programme on HIV/AIDS. (2004a). Report on the global AIDS epidemic update. Geneva, Switzerland: UNAIDS.

United Nations Programme on HIV/AIDS. (2004b). Who gets AIDS and why? Geneva, Switzerland: UNAIDS.

United Nations Programme on HIV/AIDS. (2005). Report on the global AIDS epidemic: A UNAIDS 10th anniversary special report. Geneva, Switzerland: UNAIDS.

United Nations Programme on HIV/AIDS. (2006a). 2006 report on the global AIDS epidemic update: A UNAIDS 10th anniversary special edition. Geneva, Switzerland: UNAIDS.

United Nations Programme on HIV/AIDS. (2006b). AIDS epidemic update. Geneva, Switzerland: UNAIDS.

United Nations Programme on HIV/AIDS. (2007a). 2007 AIDS epidemic update. Geneva, Switzerland: UNAIDS.

United Nations Programme on HIV/AIDS. (2007b). UNAIDS' terminology guidelines. Geneva, Switzerland: UNAIDS.

United Nations Programme on HIV/AIDS. (2008). 2008 report for Zambia. Geneva, Switzerland: UNAIDS.

Until there's a cure. (2004-2008). From http:// www.until.org.

Vine, W. E. (1981), Vine's expository dictionary of Old and New Testament words. Iowa Falls, IA: World Bible Publishers. 
Vine, W. E., Unger, M. F., \& White, W. Jr. (1985), Vine's complete expository dictionary of Old and New Testament words. Nashville: Thomas Nelson.

Walker, W. L (1996). Compassion. From International Standard Bible Encyclopaedia, Electronic Database Seattle, WA: Biblesoft.

Walque, D. de. (2006a). Discordant Couples: HIV infection among couples in Burkina Faso, Cameroon, Ghana, Kenya and Tanzania. Washington, D.C.: World Bank

Walque, D. de. (2006b). Who gets AIDS and how? The determinants of HIV infection and sexual behaviors in Burkina Faso, Cameroon, Ghana, Kenya and Tanzania. Washington, D.C.: World Bank

Webb, D. (1997), HIV and AIDS in Africa. London: Pluto Press.

White, E. G. (1908, May 1). Medical missionary work among the colored people of the south. Gospel Herald, par. 4. Retrieved from The Complete Published Ellen White Writings, www.egwritings.whiteestate.org.

White, E. G. (1940). The desire of ages: The conflict of ages illustrated in the life of Jesus. Boise, ID: Pacific Press.

White, E. G. (1946), Evangelism. Washington, D.C.: Hagerstown: Review and Herald.

White, E. G. (1947). Education. Mt View, CA: Pacific Press.

White, E. G. (1948). Ministry of health and healing. Nampa, ID: Pacific Press.

Williams, F. (2009). Social disparities in health: Evidence and promising strategies. Paper session presented at an International Conference on Health in Geneva, Switzerland.

Willis, R. J. B. (2002). The AIDS pandemic. Lincholnshire: Stanborough Press.

World Bank. (1999). Intensifying action against hiv/aids in africa: responding to a developmental crisis. Washington, D.C.: World Bank

World Bank. (2003). Local government responses to HIV/AIDS: A handbook to support local government authorities in addressing HIV/AIDS at the municipal level. Washington, D.C.: World Bank.

World Bank. (2005a). The World Bank's commitment to HIV/AIDS in Africa: Our agenda for action, 2007-2011. Washington, D.C.: World Bank.

World Bank. (2005b), The World Bank's global HIV/AIDS program of action. Washington, D.C.: GHAPaidstoday, World Bank.

World Bank. (2008). HIV/AIDS glossary. Washington, D.C.: World Bank. 
World Health Organization. (2009). Priority interventions: HIV/AIDS prevention, treatment and care in the health sector. Geneva, Switzerland.

Young, R. (1977). Young's analytical concordance to the Holy Bible. London: United Society for Christian Literature.

Zambia AIDSLaw Research \& Advocacy Network. (2006). Children's right to access hiv/aids related treatment \& services in Lusaka. Lusaka, Zambia: New Horizon Publishing.

Zambia AIDSLaw Research \& Advocacy Network (2007), Aids law manual. Alfred Chanda (late), Matrine Chuulu, Eddie Mwitwa, Kaumbu Mwondela and Richard Elliot (Eds). Lusaka, Zambia: New Horizon Publishing. 
VITA

Name: Harrington Simui Akombwa

Date of Birth: February 9, 1960

Place of Birth: Mongu, Zambia

Married: September 4, 1983 to Given Monde Simate

Children: Benaiah Simui (1984), Samuel Nambayo (1986), Moses Mubuyaeta (1989), Peter Nalumino (1992), and David Mukosiku (1994)

Education:

1968-1971 Miulwe Lower Primary

1972-1975 Nangula Upper Primary

1976-1980 St John's Secondary School

1987-1991 Bachelor of Arts in Theology, Andrews University, Solusi College, Bulawayo, Zimbabwe, graduating Summa Cum Laude.

1998-2003- Master of Arts in Pastoral Ministry, Solusi University; Graduated with a cumulative G.P.A. of 3.79 .

2007-2010 Doctor of Ministry in Leadership with Andrews University at Helderberg College, Cape Town, South Africa.

\section{Ordination:}

January 4,1994

Ordained to the S.D.A. Gospel Ministry

\section{Experience:}

May 27, 2008-Present

President, Zambia Union Conference

Aug. 12, 2004-May 26, 2008

Executive Secretary, Zambia Union Conference

Nov. 2000-Aug. 11, 2004

Executive Secretary, Zambia Union Mission

March 1999-Oct. 2000

Literature Ministry Director, Zambia Union Mission

Jan. 1995-Feb. 1999

President, West Zambia Field

Jan. 1994-Dec. 1994

Publishing Director, Zambia Union Mission

April 1993-Dec.1993

District Pastor, Mongu Central District

June 1991-March 1993

District Pastor, Kaoma Mission District

Jan. 1986-Aug. 1987

Publishing Director, West Zambia Field

July 1985-Dec. 1985

Assistant Publishing Director, Mid-West Region

and Acting Field Publishing Director, West Zambia Field

Jan. 1981-June 1985

Literature Evangelist, West Zambia Field 